University of Rhode Island

DigitalCommons@URI

Open Access Master's Theses

2012

\title{
A LABOR HISTORY OF THE RHODE ISLAND BROTHERHOOD OF CORRECTIONAL OFFICERS
}

Lisa Johnson

University of Rhode Island, lisa_johnson@my.uri.edu

Follow this and additional works at: https://digitalcommons.uri.edu/theses

\section{Recommended Citation}

Johnson, Lisa, "A LABOR HISTORY OF THE RHODE ISLAND BROTHERHOOD OF CORRECTIONAL OFFICERS" (2012). Open Access Master's Theses. Paper 97.

https://digitalcommons.uri.edu/theses/97

This Thesis is brought to you for free and open access by DigitalCommons@URI. It has been accepted for inclusion in Open Access Master's Theses by an authorized administrator of DigitalCommons@URI. For more information, please contact digitalcommons-group@uri.edu. 
A LABOR HISTORY OF THE RHODE ISLAND

\section{BROTHERHOOD OF CORRECTIONAL OFFICERS}

BY

LISA JOHNSON

A THESIS SUBMITTED IN PARTIAL FULFILLMENT OF THE

REQUIREMENTS FOR THE DEGREE OF

MASTER OF THE ARTS

IN

HISTORY

UNIVERSITY OF RHODE ISLAND

2012 


\section{MASTER OF HISTORY THESIS}

OF

LISA JOHNSON

\section{APPROVED:}

Thesis Committee:

Major Professor $\quad$ Drelyn Sterne
Dr. Robert Widell
Dr. Scott Molloy
Dr. Matthew Bodah
Nasser H. Zawia
DEAN OF THE GRADUATE SCHOOL

UNIVERSITY OF RHODE ISLAND

2012 


\begin{abstract}
Statement of the Problem: Why did the Rhode Island Brotherhood of Correctional Officers form as an independent union in 1971, and how did it develop over time and achieve its goals within a conservative labor climate? What does its history reveal about Rhode Island labor history and the broader trends in the American labor history since 1970 ?
\end{abstract}

\title{
Methodology or Procedures:
}

This study utilized the personal recollections of labor leaders, lawyers, administrative officials, and other key individuals who were present during the most crucial events throughout the union's history. The union also had a great wealth of documents to be examined. Newspaper archives (such as the Providence Journal) and state records were used to paint a broader picture and give greater context to the events. These were all compared to the existing historiography surrounding labor since the 1970's and was examined within the context of larger trends in labor established by other historians. Secondary source material regarding corrections itself was utilized to give greater meaning to changes regarding the nature of the work of correctional officers.

Findings:

The Rhode Island Brotherhood of Correctional Officers formed in 1971 as an independent union in response to inadequate representation and dangerous working conditions. While other unions fell apart during the latter half of the 1970's and the labor movement fell into a general state of disillusionment, RIBCO gained strength and momentum due to the increased funding for the prisons and the independent nature of 
the union itself. RIBCO was able to utilize the press to gain the sympathies of the citizens of Rhode Island, making them more willing to pass bond issues that would help to improve their working conditions within the facilities. The union engaged in various job actions and public discussions to make the dangers of their job known to the general public. In the 1980's, the judiciary of Rhode Island took an active role in bringing more funding into the Adult Correctional Institution (ACI). Throughout the 1980’s, relations between the officers and management (under the effective leadership of Corrections Director John Moran) improved greatly as they began to work together more frequently to solve the problems of the prison. The union grew in strength and became a force to be reckoned with. Throughout the 1980s, the union engaged in aggressive bargaining in various contract negotiations which improved its pay scale and benefits, helping it to resolve some of its issues from the 1970s. In 1991, with a riot in the maximum security building, the officers (with the support of the administration) took back complete control of maximum security. This was a turning point for the ACI and the officers' union as they attained a safe working environment. The union realized all of its goals from the early 1970s, unlike most other unions of that time period. 


\section{ACKNOWLEDGMENTS}

First of all, I would like to acknowledge the Rhode Island Brotherhood of Correctional Officers for coming forth with this project and for welcoming me with open arms. Your stories and time spent taking me on tours, in interviews, and searching for archival materials have all been invaluable to me. This has helped to make this a rewarding and memorable experience as many historians never get to actually meet those that they are studying. I owe many thanks to Ronald Brodeur, William Laurie, and Gerard Cobleigh. The long discussions and sources that you have brought to me have been extremely helpful and valuable and are very much appreciated. Also thank you to Mr. Cobleigh for allowing me to observe an actual labor arbitration. I owe a great debt of gratitude to Ken Rivard: for taking me on a tour of maximum security and the intake center, for answering my emails and phone calls, for helping to set up crucial contacts, for his initiative in setting up this project (courtesy also of Professor Molloy), and for his enthusiasm in taking part in this project. Without this, this thesis would not have been possible, and it is greatly appreciated.

Thank you to my committee, for your time and patience. In particular, thank you to Professor Sterne for taking me under your wing. Your help has been greatly appreciated. Thank you also to the Rhode Island Labor History Society for providing me with a grant which has helped to make this research possible. Your generosity is very much appreciated.

Lastly, thank you to my family, fiancé, and friends for supporting me fully while I embarked on this quest. 


\section{PREFACE}

This study will examine the innermost workings of the Rhode Island Brotherhood of Correctional Officers (RIBCO) during its forty years of its existence (from 1971-

2011). It will work to answer the questions: How did the Rhode Island Brotherhood of Correctional Officers form as an independent union? How has it developed over time and achieved its goals within a conservative labor climate? What does its history reveal about Rhode Island labor history and the broader trends in the American labor history since $1970 ?$

This union will be placed within a broader context of labor since the 1970's. As public sector labor was gathering strength throughout the 1970’s (and manufacturing unions began to decline), workers within the public sector sought representation that better suited their needs. RIBCO formed as an independent union to deal specifically with the challenges regarding work within a prison atmosphere, a highly specialized field. In forming an independent union, RIBCO managed to escape the backslide that unions, represented by larger labor organizations, faced as the era of conservatism hit. RIBCO is an interesting case study with regard to labor since the 1970's and a great example of how the goals of the 1970's became reality for some independently organized unions, like RIBCO. This study will also examine how the Rhode Island Brotherhood of Correctional Officers Union compares to other unions within the same time frame and will be used to analyze general trends within the labor movement at the time of its formation and since. It will include the contributions (such as the establishment of a competent labor force and its role in the progress of prison reform) 
that the Brotherhood has made to the state of Rhode Island and the state penitentiary system through interviews and a close examination of archival materials. This is an important study with regard to labor in Rhode Island and it also gives voice to a workforce that is not usually examined. In addition to this, a study surrounding the history of a very prominent public sector union within Rhode Island has many implications during a time of fiscal crisis for the entire nation. Rhode Island's public union sector is currently under attack and an understanding of the history of these unions is crucial and necessary in creating a constructive path forwards. 


\section{TABLE OF CONTENTS}

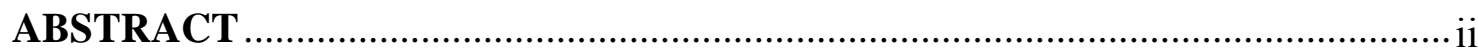

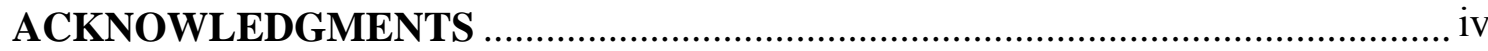

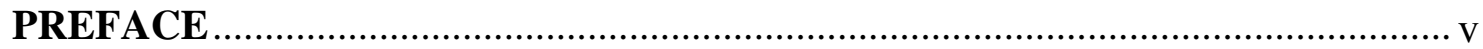

TABLE OF CONTENTS............................................................................. vii

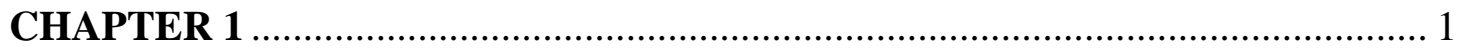

INTRODUCTION...............................................................

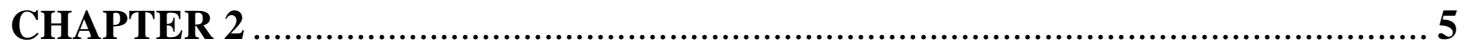

REVIEW OF LITERATURE........................................................

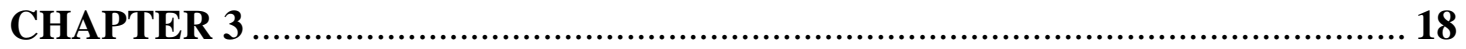

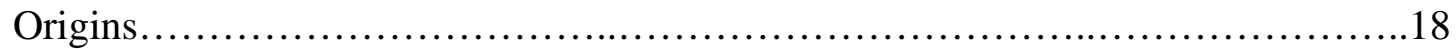

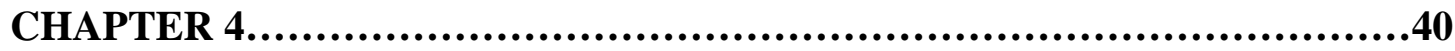

The Formative Era............................................................. 40

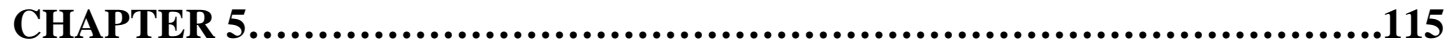

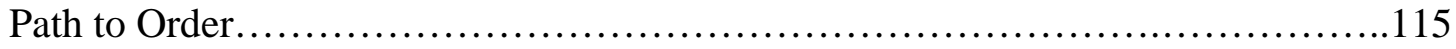

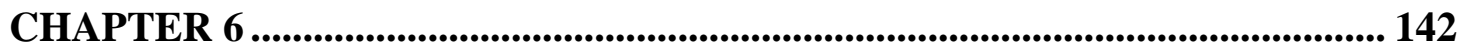

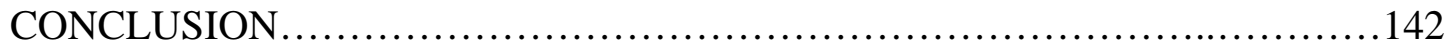

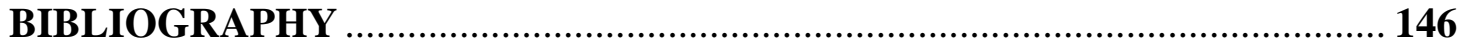




\section{CHAPTER 1}

\section{INTRODUCTION}

This work will address the following questions: Why did the Rhode Island Brotherhood of Correctional Officers form as an independent union in 1971, and how did it develop over time and achieve its goals within a conservative labor climate? It will also determine what this union's history reveals about Rhode Island labor history and broader trends in American labor history since 1970.

The Rhode Island Brotherhood of Correctional Officers was founded on December 17, 1970 by one hundred and sixteen men in the lobby of the Adult Corrections Institution of Rhode Island. They were fed up with the hazardous nature of their work, the low pay, and the constant chaos that surrounded them on a daily basis. They were in search of representation that suited needs that were specific to the nature of their work. Previously, they had been affiliated with the Local 114 of the American Federation of State, County, and Municipal Employees, but this union was not organized in a way that responded to their unique and precarious situation. Their union representatives did not understand the specialized nature of their work or the precarious situation that they were all placed in every day.

At a time when the country was experiencing an increasing level of labor militancy (with regard to the exponentially increasing number of organized strikes and wildcat strikes, internal union restructuring, and demands for a more democratic workplace), the Rhode Island Brotherhood of Correctional Officers decided to break away from the traditional labor organization and form an independent union. This union sought to make the prison a safe environment to work in and to increase pay and 
benefits. Its members created a lasting labor entity that would withstand the tests of time. In the latter part of the 1970's, other attempts at labor organizing began to crumble and the labor movement fell into a state of disillusionment as workers realized they were not meeting their goals. Corporations and state officials engaged in highly effective union busting tactics. The labor movement failed to harness the democratic sentiments of its rank and file and did not institute more democratic practices. The highest levels of union organization (ie. AFL-CIO) missed an opportunity to merge with broader social and economic movements, such as the modern phase of the civil rights movement or the women's rights movement, and thus failed to achieve greater collective bargaining power or any broader social goals regarding dignity and economic equality. The more radical elements of unions were expelled and the labor movement fractured. RIBCO, however, won small struggles and continued to grow as a labor organization. The union gained strength and momentum due to the increased funding for the prisons and the independent nature of the union itself. RIBCO was able to utilize the press to gain the sympathies of the citizens of Rhode Island, making them more willing to pass bond issues that would help to improve their working conditions within the facilities. The union engaged in various job actions and public discussions to make the dangers of their job known to the general public. At times, winning just meant surviving as an organization and living to fight the battles of another day. However, as time passed, the union developed into one of the most powerful and effective public sector unions within the state of Rhode Island. Its members worked together to create a brotherhood, in the truest sense of the word. They banded together and refused to allow another officer to 
die within the prison. Like family, they watched out for one another and protected one another.

While many unions did not endure the 1970's or the conservative atmosphere of the 1980's, RIBCO continued to persevere and work towards achieving their goals, in the distinctive way that only they could carry off. This was an age of racial strife, in which African Americans viewed themselves the "object of racial discrimination in every area of institutional life.”1 This often resulted in violent outbursts against the officers. This was the age of conservatism, in which it became popular for politicians to crackdown on public sector unions. RIBCO answered all of these challenges with appeals to the public through the press and appeals to management. Relations between the officers and management improved greatly as they began to work together more frequently to solve the problems of the prison. The union grew in strength and became a force to be reckoned with. Throughout the 1980s, the union engaged in aggressive bargaining in various contract negotiations which improved its pay scale and benefits, helping it to resolve some of its issues from the 1970s. RIBCO maintained a public presence and managed to unite with the administration and the public to finally create a path to stability and order.

In April of 1991, the prisoners engaged in an all-out riot that would damage the facilities and severely test the resolve of the prison administration and the officers. However, the officers, administration, and public had now begun to work together as a cohesive unit to finally put an end to the chaotic atmosphere of the Rhode Island prison system. Finally, the officers took back maximum security and were working within a

\footnotetext{
${ }^{1}$ Leo Carroll, Hacks, Blacks, and Cons : Race Relations in a Maximum Security Prison, Lexington, Mass.: Lexington Books, 1974, 115.
} 
system that was safer and a system in which they were valued. This was a turning point for the ACI and the officers' union as they attained a safe working environment. The union realized all of its goals from the early 1970s, unlike most other unions of that time period. As the Brotherhood celebrates its fortieth anniversary, it is clear that they have withstood the test of time and had met the goals that they had set in the 1970’s, when most other public sector unions had given up.

This study will utilize the personal recollections of labor leaders, lawyers, prison administrative officials, and other key individuals who were present during the most crucial events throughout the union's history. Traditional oral history methodology will be used. Newspaper archives (such as the Providence Journal) and state records will also be used to paint a broader picture and give greater context to the events. These will all be compared to the existing historiography surrounding labor since the 1970’s to find correlations and to trends in labor established by other historians. Secondary source material regarding corrections itself will also be utilized to give greater meaning to changes regarding the nature of the work of correctional officers.

This thesis will be broken into three major parts. The first deals with the origins of the union and its early struggles of the 1970's. The second discusses formative era between 1971 and 1977, in which the union identified its major goals and began to work to achieve them. The third section focuses on the 1980's and 1990's and demonstrates how the conservative era of politics shaped this union and how the union has now achieved its original goals. To conclude, this will discuss the present circumstances of the prison and the union and how RIBCO fits into the labor picture of Rhode Island today. 


\section{CHAPTER 2}

\section{REVIEW OF LITERATURE}

The historiography since the 1970s with regard to correctional officers' unions, and the labor movement in general, has not been not well developed or closely examined. There are two strands of material that will be examined for this thesis: the first surrounds post-war labor history and the second surrounds the correctional system itself. An analysis of post-war labor trends is necessary to fitting RIBCO into a broader schema. In analyzing these trends, a study of the system of corrections is needed to understand the nature of the work of the correctional officers and how it is affected by trends in the labor movement.

In general, historians paint a picture in which labor had a great deal of optimism which stemmed from the post-war labor mentality and manifested itself within the early 1970's. World War II was a struggle for victory abroad and victory at home with regard to the advantages of democracy being available to all. In the immediate post-war era, union members demanded that their organizations represent these values and fight for an economic climate that benefited all, regardless of class or race. Unions struggled to get through the tarnish of the communist image and yet also tried to maintain a level of liberalism and equality inherent within their movement. All of the increased class and racial consciousness came to a head in the late 1960's and early 1970's. The labor movement reached a pivotal moment in the early 1970’s and they set many goals for themselves which included traditional goals (regarding steady employment and wages), and less traditional goals (regarding more humane 
labor conditions and being treated with dignity). These goals were left by the wayside in the mid-1970's with the nation's increasing financial difficulties and the inability of the labor movement to reach beyond racial and ethnic divisions as well as divisions regarding the types of labor to fight for a common economic cause. The goals of the early 1970’s have still not been realized for most unions.

The CIOs Left-led Unions puts forth the view that race and Communism are the two major factors working against the more radical elements of the labor movement during the Cold War. This collection, edited by Steven Rosswurm in 1992, is a post-war labor history. The labor movement was fragmented due to the debate over which kinds of people to include within the unions. If the CIO continued to include more radical, Communist and Socialist followers within their organization, it believed that it would lose legitimacy within the labor movement as a whole. As a result, eleven unions were expelled from the CIO during its convention of $1949 .^{2}$

Racial inequality played a crucial role in the expulsions. The CIO was still struggling with the kinds of workers it wanted to represent: skilled (represented by a narrow margin of society) or unskilled (more racially diverse). At this time, workplace diversity was discouraged and there were fewer economic opportunities available to minority groups. ${ }^{3}$ The CIO, in an attempt to maintain its legitimacy with the American public, sought to create a more moderate tone by eliminating its more radical and diverse factions. ${ }^{4}$ This collection's intent is to suggest that the labor movement might have changed direction or perhaps been more successful, had it incorporated these

\footnotetext{
2 Steve Rosswurm, The CIO's Left-led Unions (New Brunswick, N.J. : Rutgers University Press, 1992), 119-138.

${ }^{3}$ Rosswurm, 69-94.

${ }^{4}$ Rosswurm, 139-158.
} 
members. ${ }^{5}$ The CIO could have maintained its solidarity and strengthened its stance instead of weakening their position in the hopes that they would gain allies. This created a bitter splintering of the labor movement which it has still not recovered from.

In The State and Labor in Modern America (1994), Melvyn Dubofsky stresses that the power of the working-class people is exaggerated, which is a response to the surrounding historiography that deviates from traditional trends and counters the ideas of other historians (as seen in Rosswurm's collection of articles). He argues that historians have spent too much time emphasizing "ethnicity, gender, race, shop-floor traditions, and discursive ideologies”. 6 He argues for a broadened perspective that deals with "patterns of trade union growth and decline" and "the persistent dominance of capital in its relations with labor". ${ }^{7}$ He points to the fact that unions, after 1983, continued to lose millions of members and made many concessions despite an upturn in the American economy. ${ }^{8}$ Dubofsky examines what he terms "tangible labor policies" instead of changes in national values. ${ }^{9}$ He traces the patterns of national labor policy and the development of state intervention with regard to labor from the 1870's up through the early 1990’s.

The post-war period is one in which Dubofsky suggests that labor carried within itself "the seeds of its own destruction". ${ }^{10}$ While the system appeared to be functioning beautifully on the surface, it was headed for disaster as a result of internal and external stressors. The Hartley-Taft Act of 1947 set back national labor policy by banning

\footnotetext{
${ }^{5}$ Rosswurm, 1-17.

6 Melvyn Dubofsky, The State \& Labor in Modern America (Chapel Hill : University of North Carolina Press, 1994), xi.

${ }^{7}$ Dubofsky, xi.

${ }^{8}$ Dubofsky, xii.

${ }^{9}$ Dubofsky, xiii.

${ }^{10}$ Dubofsky, 198.
} 
closed shop, restraining the establishment of union shops, allowing federal courts to issue antistrike injunctions, and letting states reject all forms of union security (through laws such as "Right to Work" laws which made it illegal to keep union membership as a condition for employment).

With the addition of African Americans and women to the workforce and unions, public resistance against the movement grew through the 1950's and 1960's. The AFL-CIO (which merged in 1955) found itself conflicting with civil rights legislation. Traditionally labor restricted access to craft unions to skilled workers only to maintain bargaining power. In maintaining a monopoly of the skilled workforce, labor could easily control big business. In reality, this discriminated against minorities (with regard to race and gender) who largely made up the unskilled workforce. While labor endorsed these laws and fundamentally agreed with the principles contained therein, Title VII of the Civil Rights Act of 1964 (which prohibits employment discrimination based on race, color, religion, sex and national origin) helped to destroy their solidarity as a bargaining unit. The economic shocks of the 1970's dismantled the economic stability the nation had enjoyed and did nothing to help the cause of labor. Labor could no longer depend on the federal government to intervene on their behalf. The times became increasingly conservative. Trade unions failed to reform labor law. It became clear that labor could not defeat the economic and political problems facing it. $^{11}$

Labor historians have not given the 1980's much study and the historiography surrounding this era is lacking. Jonathan D. Rosenblum, in Copper Crucible (written in 1995), takes a case study approach to labor in using the Arizona's miners' strike of 1983

\footnotetext{
${ }^{11}$ Dubofsky, 195-238.
} 
and asserts that this strike changed labor-management relations throughout the country as a whole. This book helps to give insight to labor as a whole during the early 1980's and paints a picture of how relationships between management and labor became much more aggressive and the spirit of cooperation had disappeared. This statewide strike was held against the Phelps Dodge Corporation, a titan in the copper mining industry. It started on June 30, 1983 when twenty four hundred mine workers became enraged by cuts in wages, medical benefits, and vacation time. Phelps Dodge refused to accept terms that other corporations in the copper mining industry were accepting and used federal labor laws to back up its actions. ${ }^{12}$

Labor now had a slew of roadblocks in its way, and situations often escalated to the point of violence. The press had a crucial role in swaying public opinion during this tough economic time. ${ }^{13}$ Physical force, once employed by the companies themselves, was now being provided by the government and was done with the blessing of the taxpayers (keeping in line with the conservative mentality of the time). When the corporation did not get the governor to bring in the National Guard, it was forced to shut down. They took the issue to the state legislature and used their lobbying powers to pass legislation in favor of the strikebreakers. ${ }^{14}$ When it became clear that the company would use the strikebreakers to reopen, the governor realized that this situation would escalate. ${ }^{15}$ He called in the National Guard to keep the peace but violence broke out. ${ }^{16}$ In the end, it was the federal judicial system that killed the strike in 1986 with an appeal

\footnotetext{
12 Jonathan D. Rosenblum, Copper Crucible : How the Arizona Miners' Strike of 1983 Recast Labormanagement Relations in America (Ithaca, N.Y. : ILR Press, 1995), 3-4.

${ }^{13}$ Rosenblum, 85-88.

${ }^{14}$ Rosenblum, 96-103.

${ }^{15}$ Rosenblum, 107.

${ }^{16}$ Rosenblum, 108-109.
} 
to the National Labor Relations Board. The union was decertified based on the fact that the union members had been replaced. ${ }^{17}$ This was a move that was not in line with the tradition of the National Labor Relations Board. It became clear that union strength had taken a hard hit with regard to the right to strike and worker solidarity. ${ }^{18}$ Once public opinion had turned, the full force of each branch of government, at different levels, was used to break apart union power. This book makes clear the destructive power an economic downturn has on labor. This strike became a "symbol of defeat for American unions". 19

While most authors view the external stressors as being the major obstacles for unions, historian Jefferson Cowie presents the internal divisions as being the most important obstacle of all. "Portrait for the Working Class in a Convex Mirror: Toward a History of the Seventies”, written by Cowie in 2005, re-examines labor in the 1970’s with a different approach. This author argues that the real struggle within the labor movement was over class divisions. This argument demonstrates a clear shift in the historiography. In focusing on class divisions as the central problem within the labor movement, Cowie stresses a grassroots interpretation of the movement that is more inclusive and offers a fresh approach on the material and problems therein. The author explains this decade as "a bridge between eras". ${ }^{20}$ While the first half of the era (within the early 1970's) suggested a great amount of progress and promise for workers, the second half (the latter part of the 1970's into the 1980's) was disappointing in its

\footnotetext{
${ }^{17}$ Rosenblum, 195-199.

18 Rosenblum, 217.

${ }^{19}$ Rosenblum, 217.

${ }^{20}$ Jefferson Cowie, "Portrait of the Working Class in a Convex Mirror: Toward a History of the Seventies." (Labor: Studies in Working Class History of the Americas 2, no. 3 (Fall 2005): 93-102. America: History \& Life, EBSCOhost (accessed February 23, 2011)), 93.
} 
regression and recognition of limits. Cowie asserts that as economic inequality skyrocketed during this decade, discussions about class conflict and the issues of the lower classes dwindled. Economic growth slowed and unemployment rose and yet Americans were hesitant to tackle their demons. Political identity shifted away from economic status. Historians, according to Cowie, should investigate this gap between "the politics of economic reality and the politics of identity and imagery". ${ }^{21}$

Within the political realm, standing up to public sector unions "became the litmus test of a politician's sense of fiscal responsibility”. ${ }^{22}$ The public questioned spending and, at least within the public sector, it no longer became feasible to replace striking workers. This tactic was used much more within private business, as private business did not have the public sentiment to contend with. ${ }^{23}$ Major impediments to unions during the 1970's were labor consultants and lobbying operations. These were critical factors that worked to defeat specific unions and helped to end labor law reform in Congress. ${ }^{24}$ This directly contradicts authors like Dubofsky who argued that the federal bureaucracy was the only thing working to protect workers during this time period. Cowie also states that the distance between union members and the rest of the American public grew and both groups lost touch with one another. ${ }^{25}$

In a more recent work, Stayin' Alive: The 1970's and the Last Days of the Working Class (2010), Cowie uses various cases across the nation in various types of industries to develop the idea of class divisions within the labor movement and how the dialogue regarding class changes with the new conservative era. He views it as a

\footnotetext{
${ }^{21}$ Cowie, "Portrait of the Working Class", 97.

${ }^{22}$ Cowie, "Portrait of the Working Class", 98.

${ }^{23}$ Cowie, "Portrait of the Working Class", 96-98.

${ }^{24}$ Cowie, "Portrait of the Working Class", 99.

${ }^{25}$ Cowie, "Portrait of the Working Class", 99.
} 
movement that was reaching towards specific goals (including more humane conditions and being treated with dignity) and yet never quite ended up attaining them. The democratic mentality of the nation's unionized workforce broke down with racial integration and an economy that was in turmoil. ${ }^{26}$ Therefore, labor’s actions became “a conflicted set of movements" and the cohesiveness of spirit and ideology seen at the beginning of the decade began to disintegrate. ${ }^{27}$ This ended the decade with a period of disillusionment and demoralization and the vision of the labor movement was lost.

Cowie analyzes the problems of the 1960’s and early 1970’s and how workers initially were on the right track to identifying them and fixing them. The demands of workers in the seventies as included: union democracy, a good quality of work life, health and safety at the workplace, and a desire for fresh leadership. ${ }^{28}$ He uses examples such as the inactivity of the United Mine Workers Association during a situation in which many miners were trapped within Consolidated Coal mines in Farmington West Virginia (in 1968). This inactivity proved how out of touch labor leadership could be with the needs of the workers they represented. ${ }^{29}$ Union leadership (now part of an economic elite) was also faulted for not rising to meet the social demands of its workers that surfaced in the 1960's. At the beginning of the 1970's three things became clear to workers: they could work outside of the union bureaucracy to achieve their goals, the young workers were more discontent as time went on, and the federal government was clearly getting in the way with its business-backed law. ${ }^{30}$ Union members wished to

\footnotetext{
${ }^{26}$ Jefferson Cowie, Stayin' Alive: The 1970's and the Last Days of the Working Class (New York : New Press, 2010), 3-7.

${ }^{27}$ Cowie, Stayin'Alive, 7.

${ }^{28}$ Cowie, Stayin'Alive, 24.

${ }^{29}$ Cowie, Stayin'Alive, 30.

${ }^{30}$ Cowie, Stayin’Alive, 32-24.
} 
have a union that encompassed a greater diversity of workers. ${ }^{31}$ The economic and political climate changed and this, in turn, helped to change the tides of the national labor discourse. ${ }^{32}$ Race, gender, sexuality, and religion "were eclipsing class as points of reference in political life”. ${ }^{33}$

As the seventies drew to a close, it seemed to many that "workers' sense of entitlement" and "union power" were "at the root of the nation’s problems". ${ }^{34}$ Stagflation and the energy crisis helped to create a sense of collective panic and corporations organized and rebounded from the attack by labor. Corporations utilized political action committees and pushed for more anti-union legislation now that public opinion had clearly taken a turn against labor. ${ }^{35}$ The Supreme Court moved to sanctify these legal actions. Finally, President Ronald Reagan helped to ultimately reverse all of the gains made in the 1970's with his strikebreaking tactics, as evidenced by his showdown with the Air Traffic Controllers. Cowie sees the Reagan presidency as something that "devastated the workingman". ${ }^{36}$ All around, there was disparity and a lack of class consciousness coupled with the sense that an opportunity was lost.

In order to understand how trends in labor history relate to RIBCO, the historiography surrounding the development of the penology system is needed to understand the nature of the work of a correctional officer and how it is thus affected by labor trends. Analysis of the development of the American penology system is necessary when studying the nature of work within American prisons. In general, the

\footnotetext{
${ }^{31}$ Cowie, Stayin'Alive, 38-68.

${ }^{32}$ Cowie, Stayin'Alive, 75-167.

${ }^{33}$ Cowie, Stayin'Alive, 216.

${ }^{34}$ Cowie, Stayin'Alive, 224.

${ }^{35}$ Cowie, Stayin'Alive, 234.

${ }^{36}$ Cowie, Stayin'Alive, 311.
} 
prison system is seen as a mechanism by which to control segments of the population that are unsavory. Throughout its evolution, it has become increasingly more bureaucratic and political. Within Rhode Island, this has held also true.

Michel Foucault, French historian and philosopher, examined theories around punishment and how it has developed over time. In the book Discipline and Punish: the Birth of the Prison, Foucault traces the roots of the prison system from medieval times and explains the motivations of those who helped to shape the system throughout the ages. The aim of punishment was to deter crime and to apply ideas of reason to justice, with individualized correction also being a major facet of this new way of administering justice. ${ }^{37}$ An entirely new system developed to accommodate this punishment. Out of this came a need for organization and discipline. The space of the prison became highly regulated and monitored and the activities within that space were strictly regimented. ${ }^{38}$ Foucault describes the organization of systems of separation for means of "surveillance and control" which helped to expand the power of rulers. ${ }^{39}$ This led to the branding and isolation of groups that did not follow the normal mainstream inclinations. Usually, the constant observation was enough to keep prisoners in check and keep the supervisor in a dominant position. Actual threats were not necessary. In addition to this, troublesome segments of the population were split apart and kept from uniting to overthrow the powers that be. ${ }^{40}$ This also allowed for experiments to be performed on various human subjects. ${ }^{41}$ One could argue that these experiments could take various forms, such as the

\footnotetext{
${ }^{37}$ Michel Foucault, Discipline and Punish: The Birth of the Prison (Random House: New York, New York, 1975), 95-102.

${ }^{38}$ Foucault, 151-167.

${ }^{39}$ Foucault, 196.

${ }^{40}$ Foucault, 197-198.

${ }^{41}$ Foucault, 199-200.
} 
"reforming" and "rehabilitative" programs that exist in present day society. This system gave the public the right to come in and inspect it at will so that it would not become a tyrannical system. ${ }^{42}$ The system was designed, not only to control those within the walls of the prison, but also those outside within the larger realm of society. ${ }^{43}$

Foucault then delves into the greater consolidation of policing powers throughout the eighteenth century and into the modern age. This created a system in which there was a "codified power to punish" and "the universal punishments of the law are applied selectively to certain individuals and always the same ones". ${ }^{44}$ The author makes the disturbing point that prisons resemble "factories, schools, barracks, hospitals, which all resemble prisons". ${ }^{45}$ It is clear that Foucault views the prison system as a system which just increases the power of those in the upper echelons of society and perpetuates itself in a manner that works to further control those who are in the lower rungs of the societal ladder. Prisons then act as breeding grounds for delinquency, in that they do not actually seek to solve the problem of crime, yet help to perpetuate it. ${ }^{46}$ Prisons are rooted in power and are perpetuated by elements seeking to maintain their power within the larger society.

American Penology: A History of Control by Thomas Blomberg examines the expansion correctional system throughout the course of American history and also asserts that this is a way for the government to keep an increasing amount of control over the American population. The book's greatest strength is that it examines the

\footnotetext{
${ }^{42}$ Foucault, 201.

${ }^{43}$ Foucault, 202.

${ }^{44}$ Foucault, 224.

${ }^{45}$ Foucault, 228.

${ }^{46}$ Foucault, 265-268.
} 
“specific historical conditions" surrounding each "penal reform era” ${ }^{47}$ The book examines the penal system from the 1600's to 2009.

With regard to the penology system in Rhode Island, the works of Leo Carroll are invaluable. Hacks, Blacks, and Cons : Race Relations in a Maximum Security Prison, written in 1974 studies the Rhode Island prison system, from the prisoners' perspective at a crucial point in the history of the Brotherhood of Correctional officers. Largely this work is crucial in gaining the perspective of the prisoner population, specifically with regard to race and reforms. This is part of that body of work and helps to describe conditions, policies, and reforms within the ACI during a crucial era in the union's formation.

Lawful Order : a Case Study of Correctional Crisis and Reform written by Leo Carroll in 1998 explains some of the reforms which were undertaken within the Rhode Island prison system and connects these reforms to the broader reform movements going on throughout America at the same time. This is a critical work in that needs to be reviewed in examining state intervention within the prisons, on behalf of the prisoners. Carroll examines how the reform efforts of the judiciary changed the system within the state of Rhode Island. He asserts that Rhode Island was very different from other states in which judicial reforms have been instituted in that: there was no capital punishment statute, the state endorsed rehabilitation ideals in the 1950's and 1960's, the prisons were operated by the state, the media was extremely influential within such a small state, and the correctional officers were among the first officers to

\footnotetext{
${ }^{47}$ Thomas G. Blomberg, American Penology : a History of Control (New Brunswick, N.J. : AldineTransaction, 2010), 1.
} 
unionize. ${ }^{48}$ He argues that in this case, as well as in most judicial intervention cases, the legal basis of intervention comes from the Eighth Amendment (which makes it illegal to institute cruel and unusual punishments), in which a "totality of conditions" warrants judicial intervention. ${ }^{49}$ Inherent in this is how this intervention affected the nature of work of the correctional officers of Rhode Island. Carroll argues that judicial intervention improved the physical conditions within archaic structures and helped to remedy some of the most flagrant abuses within the system. ${ }^{50}$

All of these sources give a plethora of background surrounding post-war labor history, the system of corrections, and the Rhode Island system of corrections in particular. While some of these sources have been examined by historians before, they have not been examined within this light. Overall, the post-war period of labor history is presented by scholars as being one of potential and hope, which ultimately led to a splintering of the movement in the latter half of the 1970's. Public sector workers are presented as having borne the brunt of the abuse as the conservative era marched on. The study of the history of RIBCO intersects between all of these subjects and intertwines to tell a history of an unstudied segment of workers in a largely unexamined time period.

\footnotetext{
${ }^{48}$ Carroll, Lawful Order, 22-23.

${ }^{49}$ Carroll, Lawful Order, 127.

${ }^{50}$ Carroll, Lawful Order, 8.
} 


\section{CHAPTER 3}

\section{Origins}

The 1960’s and early 1970’s were a time of turmoil for the entire nation. Racial tensions were running high as race riots broke out across the nation. The atmosphere became only more tumultuous with the death of civil rights leader Dr. Martin Luther King Jr.. The American people were losing faith in their government to handle problems both at home and abroad and were vociferously advocating against the Vietnam War. American labor also became caught up in this wave of change and activism. Workers across the nation united and protested their conditions, using a variety of job actions and demonstrations to make their voices heard. They demanded dignity, a democratic partnership with management, and sought to purge their stale union leadership. Workers vented their frustrations and disappointment in a government and economic system that led them to buy into the post-war dream of prosperity for all. In actuality, the times were getting tougher and survival was more difficult. It seemed as though the once optimistic and confident expectation for the future was now a distant dream and the future seemed wrought with anxiety and uncertainty.

This was a time period in which the correctional officers in the state of Rhode Island realized that their needs for a labor organization were not being met. They were affiliated with the Local 114 of the American Federation of State, County and Municipal Employees (AFSCME), which represented all kinds of public sector 
workers within the state of Rhode Island. While these representatives were talented, they did not understand the specifics of the prison work environment. AFSCME was not taking on cases that would benefit the correctional officers. In addition to this, officers feared for their safety on a daily basis due to the chaos and lack of control within the prison environment. The officers felt they needed to respond to the daily chaos and turmoil that threatened the safety of its officers. The conditions within the prison system were squalid and abuses within the system ran rampant. In an attempt to bring attention to their concerns, officers engaged in wildcat actions, not sponsored by AFSCME. These wildcat actions were indicative of the broader spirit of the labor movement of the early 1970s, as the rebellious rank and file was often discontented with their ineffective representation. Officers did not have any advocates or allies within the system of corrections, and therefore united to advocate for themselves. Officers engaged in wildcat action because immediate action was needed to ensure the safety of all of the workers. However, these workers then took action in an unconventional way. By December of 1970, officers decided that they were in need of new representation by those who best understood the job, themselves.

The Providence Journal, in an article titled "Year of Strikes - Maybe More Coming”, encapsulated the mood of the state of Rhode Island in beginning the new year of 1970. It was clear that 1969 had been an extremely active year on the labor scene for the state. In 1968, there had been twenty-five work stoppages; in 1969, the number jumped drastically to forty work stoppages. It was anticipated that this level of activity would be maintained in the new year as labor demands for higher pay and 
better benefits as well as dignity and democracy in the workplace has still not been met. It was expected that the "areas of construction and public employment [would] continue to be areas of high labor activity,” as workers negotiated contracts and advocated and proposed legislation that would "increase the strength of employees in collective bargaining” for those working in the public sector. ${ }^{51}$ It was anticipated that the coming negotiations for the year of 1970 would affect five million workers throughout the nation. ${ }^{52}$ The unemployment rate for Rhode Island was just slightly above the national average, at 3.5 percent. ${ }^{53}$ Also, a previous strike in the construction sector "raised the pay expectation of workers in other industries" throughout the state followed directly by a strike by the Providence Teachers Union, who sought higher pay and eventually a strengthened position for public sector workers in collective bargaining. ${ }^{54}$ The 1966 Teachers Arbitration Act had worked against the union's right to strike and they were hoping to pass legislation to modify this act. ${ }^{55}$ If passed, this legislation would affect the public sector as a whole.

While the entire state of Rhode Island was experiencing the same tensions the rest of the nation was experiencing, the Adult Correctional Institution of Rhode Island (ACI) was also defined by a state of bedlam and peril. The institution was constantly plagued by inmate disturbances, rioting, fires, escapes, fights among inmates, contraband, and attacks on officers. Lt. Ken Rivard, current grievance chair for the RIBCO and previous RIBCO president, defines the situation as "very chaotic" and

\footnotetext{
51 "Year of Strikes - Maybe More Coming," The Providence Journal, January 4, 1970, F16.

${ }^{52}$ Ibid.

${ }^{53}$ Ibid.

${ }^{54}$ Ibid.

${ }^{55}$ Ibid.
} 
asserts that "the inmates ran the prison at the time". ${ }^{56}$ He describes his first day as "just like being at the mall, they [the inmates] [were] all around you" ${ }^{57}$ There was no sense of order or organization. Capt. Ronald Brodeur (a shift supervisor, $2^{\text {nd }}$ Vice president, and president of RIBCO for seven years in the 1980s) hired on October 14, 1973, also asserts that the prison was "very dangerous” and "out of control” and maintains that "the prisoners ran the place" ${ }^{58}$ Both men recall the very real sense of danger that they encountered on a daily basis, as officers were taken away in ambulances almost on a daily basis. In listening to their recollections, one wonders which group was truly held prisoner: the inmates or the officers.

On December 10, 1969, twenty inmates began a disturbance that was typical of the time. These twenty prisoners had been placed into the segregation unit for previous offenses and, after making a trip to the new exercise yard (one day old) that was built especially for those confined to segregation, they refused to go back to their cells when asked. The inmates then "burned mattresses in their cells, threw food and excrement outside and pelted the guards with objects”. ${ }^{99}$ The warden worked to set up a disciplinary board so that the officers could lodge complaints against inmates. Yet, as officers were being pelted with objects and were putting out fires and dodging excrement, the inmate organization (the “JayCees”) was holding a Christmas party for the inmates. Sadly, this event characterizes the state of the prison at this time and is only one of many in a long list of disruptions.

\footnotetext{
${ }^{56}$ Ken Rivard, Interview with the author, March 29, 2011.

${ }^{57}$ Ibid.

${ }^{58}$ Ron Brodeur, Interview with the author, March 17, 2011.

59 “Disturbance Staged by 20 at the ACI,” The Providence Evening Bulletin, December 11, $1969,1$.
} 
Fourteen of the men who were agitators in the disturbance and nine others were, at the time, involved in a suit in federal court which asserted that they were “'discriminatorily' singled out as ringleaders and forced to live in squalid conditions” which constituted "cruel and unusual punishment". ${ }^{60}$ While these conditions were terrible, a great degree of the "squalid conditions" were created by the inmates themselves. For example, these inmates were not served dinner, not as a punishment, but because the administration was concerned for the safety of the officers. After two inmates were served dinner, they threw the dinner right back out of their cells at the officers. ${ }^{61}$

In an expansion of this original federal suit, a civil rights suit was brought to the U.S. District Court by the prisoners to challenge the new prisoner classification system. ${ }^{62}$ The purpose of the suit was to make sure that there were some safeguards of due process with regard to notice for hearings and the ability to call witnesses or crossexamine witnesses for their hearings. ${ }^{63}$ A great degree of prisoner frustration and officer frustration came from the fact that there were not any clear administrative policies or directives. William Laurie, former assistant director for adult services in the 1970's (who held all of the responsibilities of a warden), affirms that the previous administrations of the 1960's had allowed the place to "go to hell" ${ }^{64}$ In attempting to follow the more liberal philosophies of the National Correctional Association and federal government bureaucrats, the previous director of corrections for the ACI and

\footnotetext{
${ }^{60}$ Robert F. Baldwin, “20 Inmates Go Without Any Supper,” The Providence Journal, December 12, 1969, 18.

${ }^{61}$ Ibid.

62 “Inmate Suit Mounts Broad Attack on ACI,” The Providence Evening Bulletin, December 19, 1969, 41. ${ }^{63}$ Ibid.

${ }^{64}$ William Laurie, Interview with the author, August 3, 2011.
} 
the rest of the bureaucracy allowed the conditions to deteriorate and the administrators "lost control" of the prison. ${ }^{65}$

In losing control of the prison, they also lost the public's faith that their money would be well-spent on this dilapidated prison system. At this time, there were no adequate rehabilitative programs and any kind of programs that did exist were ineffective due to their lack of support and funding. ${ }^{66}$ Funding that did come into the prison came from federal grants that were sparse and were not guaranteed funding for the prison to rely on. ${ }^{67}$ This created conditions which fostered rebellion and despair. Members of the community, such as Julio Costa (a correctional officer who also acted as an athletic coach at the ACI), made a plea within the Providence Journal Bulletin for more funding to keep the inmates occupied with activities. ${ }^{68}$ As a person who was intimately acquainted with the daily lives of the inmates, he spoke to the fact that idleness causes disruptive behavior and that programs would help rehabilitative efforts. He explained the need for more funding to keep any kind of recreation activity going, as the little equipment that they had was wearing out. ${ }^{69}$ In addition to this, the constant rioting and fire-setting left the facilities in a constant state of disrepair. One fire on May 23, 1969, destroyed two-thirds of the maximum security

\footnotetext{
${ }^{65}$ Ibid.

${ }^{66}$ Ibid.

67 “ACI launching Full Vocational Program,” The Providence Evening Bulletin, January 2, 1970, 19.

${ }^{68}$ George Popkin, "He Provides a Valve for the Endless Days," The Providence Evening Bulletin, January 6, 1970, 2.

${ }^{69}$ Ibid.
} 
building. ${ }^{70}$ Nine months later, the building still had not been restored to normal. ${ }^{71}$

The cost of the damage from this fire came to nearly $\$ 350,000 .^{72}$

Sadly this lack of funding for supplies continued into later administrations. William Laurie attempted to rectify this as Assistant Director of Adult Services. He had a contact within the General Services Administration (GSA) in Washington which deals with government surplus and could have provided the ACI with uniforms for the inmates, trucks, and washing machines. The governor of the Rhode Island would not sign the request, however, due to political reasons. The governor was a Democrat and could not be seen accepting "goodies" from a federal government agency that was under a Republican presidency. ${ }^{73}$

Another area that desperately needed funding was the officer training program. Ken Rivard put it best in stating: ““'I had no idea what I was getting into.”74 He was hired by the warden, after an interview with the warden and was thrown right into the fire without any kind of training whatsoever. There were no weapons or night sticks and they were issued whistles to alert other officers to trouble. However, this was not foolproof as this sometimes resulted in officers "run[ning] the other way" ${ }^{75}$ A year after this, they instituted a one week training session, and today, there is a ten week pre-service training academy, at the union's insistence.

This dilemma over federal funding continued well into the 1970's and 1980's, as did the politics behind it, as we will see in later chapters. One of the major

\footnotetext{
70 “ACI Repairs Windup Promised,” The Providence Evening Bulletin, January 10, 1970, 1.

71 “Top Security ACI Inmates Return Set,” The Providence Journal, February 25, 1970, 2.

“Top Security ACI Inmates to be Moved,” The Providence Journal, March 3, 1970, 17.

72 "Progress Made in ACI Repairs,” The Providence Journal, February 3, 1970, 17.

${ }^{73}$ William Laurie, Interview with the author, August 3, 2011.

${ }^{74}$ Ken Rivard, Interview with the author, March 29, 2011.

75 Ibid.
} 
challenges that faced the officers was the fact that the public did not truly understand the nature of their working conditions. The officers found that they needed to make the public aware of their circumstances so that the public would realize that the conditions were within their power to change, with funding. As circumstances became more dire and dangerous, the public would eventually realize that something had to change for the conditions within the prison to turnaround. ${ }^{76}$

This has been the great dilemma that all public sector unions and workers have had to face. They have been completely dependent upon the public for the funding that shaped their working conditions. Workers have discovered that, while there were still the same demands from the shop-floor "managers", their "managers" or administrators need to answer to a larger boss who ultimately has decided their funding and their fate, the American public. The American public has always been quite hesitant to spend money on anything it doesn't have to and has always been looking for ways to cut public spending. Administrators, caught in the middle, have been unlikely to take a strong stance, for fear of angering the public who employed them. An ugly pattern of finger-pointing usually results and accountability has then been lost by the wayside. In this political game the only people left holding the bag has been the workers themselves. In this case, the correctional officers were consistently placed in dangerous predicaments and risked their lives each day. They had no choice but to unite for their own safety.

\footnotetext{
${ }^{76}$ Ronald Brodeur (former RIBCO president and retired captain) makes it clear that, throughout this long struggle, management "has not had safety as their priority" and that "if it weren't for the union, management would make decisions that would jeopardize the safety of the officers".

Ron Brodeur, Interview with the author, March 17, 2011.
} 
This was a time in Rhode Island's history in which the mob was heavily influential, both in the prison and political system. Lt. Rivard describes the situation as: "Whatever the inmates wanted, they would get." ${ }^{, 77}$ He recalls the steaks and seafood brought in by outside vendors for the privileged few, and this was condoned by the administration. ${ }^{78}$ Also, there was an incident in which the administration even authorized a goat to come into maximum for an inmate. ${ }^{79}$ William Laurie, former assistant director of adult services, recalls the special furloughs that had been granted during the administration before his own. In one case, a particularly powerful mobster (and convicted murder) had always been granted a furlough for Thanksgiving. Laurie denied the request upon entering into the job. His describes his reasoning as such: "Here's two officers, who are working during Thanksgiving, taking a murderer (and a nasty guy)... and [they are] standing in the other room while he had dinner with his family...talk about demoralizing your staff., ${ }^{, 00}$ Clearly, the prison was being run, not by the state officials, but by the prisoners themselves.

In addition to mob control and influence, the NPRA (National Prisoner's Rights Association, founded in Rhode Island) had extensive control within the prison. This continued up through when the state reclaimed the prison and placed key members of the NPRA in the segregation unit. ${ }^{81}$ The NPRA pushed for legislation, was involved in the media, and advocated for prisoner rights. Within the prison, they controlled much of the politics behind the uprisings. Internal (comprised of prisoners

\footnotetext{
${ }^{77}$ Ken Rivard, Interview with the author, March 29, 2011.

${ }^{78}$ Ibid.

${ }^{79}$ Ibid.

${ }^{80}$ William Laurie, interview with the author, August 3, 2011.

${ }^{81}$ Lee Bernstein, America is the Prison: Arts and Politics in the Prison in the 1970's, Chapel Hill: University of North Carolina Press, 2010, 73.
} 
themselves) and external boards (comprised of friends and relatives) of advocates worked to ensure prison reform, but they also took advantage of the power vacuum that existed and utilized this to gain access to special privileges and goods. They sponsored events for all of the prisoners and also ran a restaurant on the premises. ${ }^{82}$ The Jaycees (an internal group affiliated with the larger United States Junior Chamber organization which focuses on training and community service) were another strong internal inmate group. This group also promoted events such as Family Day. ${ }^{83}$ This created some security issues as the Family Day grew in size and scope, often bringing hundreds of people into the prison. ${ }^{84}$ The second annual Family Day had 600 people in attendance. ${ }^{85}$ As the leadership of the administrations grew weaker, the inmate organizations stepped up to take advantage of the power void.

In May of 1969, a report drawn up by James Bennett, former director of the U.S. Bureau of Prisons, outlined various changes that should be made to improve the ACI. This was in response to a riot in January of 1969. As of February 1970, some of the suggestions were implemented, and some problems had yet to be addressed. The suggestions that were implemented consisted of raising the pay of the correctional officers (to attract new personnel), obtaining federal funds, and the creation of a comprehensive management survey (the goal of which was to create a chain of command). Other suggestions that had not been implemented consisted of: decreasing the overtime of officers, creating an “'in-depth study' of present duty posts of

\footnotetext{
${ }^{82}$ William Laurie, Interview with author, August 3, 2011. Ken Rivard, interview with author, March 29, 2011.

83 “ACI Officials Experiment with 'Family Day',” The Providence Journal, August 10,1970, 26.

${ }^{84}$ William Laurie, Interview with author, August 3, 2011; and Ken Rivard, interview with author, March 29, 2011.

${ }^{85}$ Ibid.
} 
officers," making changes to the maximum security building and to solitary confinement cells, and appointing a board of civilians to help develop the industrial workshops and education and training programs. Bennet argued that if all of the officer's positions were filled, the state would not need to spend so much on overtime and could put that money to better use elsewhere. It was felt that "community cooperation and involvement” was urgently needed to turn the situation around. ${ }^{86}$

Meanwhile, the prisoners were finding advocates in state legislators and U.S. District Court Judge Raymond Pettine. State legislators, who had consulted with inmate organizations, were pushing through legislation that would benefit lifers in prison: those serving life sentences would be paroled after ten years instead of twenty; donating a pint of blood would give the prisoners 10 days, instead of 5 days off of their sentence; and lifers could participate in the work-release programs. ${ }^{87}$ At the same time, Judge Pettine began to hear the complaints from prisoners regarding the classification system and the state of the prisons. He found that prisoners were being discriminated against, on the basis of race, as they were placed in the segregation unit (the Behavioral Control Unit) frequently and were not given opportunities for workrelease or parole. Also, he found that conditions within the prisons were inadequate, particularly regarding medical care and food. He prepared for further proceedings regarding the conditions of life within the segregation unit of maximum security. ${ }^{88}$

These proceedings greatly affected the atmosphere of the prison and were the catalyst for a great deal of the reforms within the prison. While ultimately the orders

\footnotetext{
${ }^{86}$ Robert Baldwin, “ACI Still Short of Fulfilling Changes,” The Providence Sunday Journal, February 8, 1970, N 36.

87 "Three ACI Bills Are Introduced,” The Providence Journal, March 6, 1970, 14.

${ }^{88}$ C. Elliott Stocker, “Judge 'Hears’ Prisoners,” The Providence Evening Bulletin, March 11, 1970, 1; and "ACI Inmates Claim Prison Violates Rights," The Providence Evening Bulletin, June 29, 1970, 29.
} 
of Judge Pettine would help to bring in the necessary funding that the public refused to approve, the rulings initially brought a great deal of frustration to the workers (namely the correctional officers). Pettine began by creating a series of protocols which reinforced "due process" within the disciplinary processes in the prison. However, this created a lot of confusion and upset those who were attempting to carry these policies out. At some points, enforcement was not consistent and procedure was unclear to the workers. This appeared to further convolute the already confusing system of procedure and also appeared to take away the authority of the officers within the working environment. Officers, in a meeting with Pettine, exclaimed: “we're all on medication now and we're running out of pills," in an attempt to explain how the system wasn't working and demonstrate their fear that this would break it further. ${ }^{89}$ One officer protested: "We find it impossible to run this place under these foolish rules." ${ }^{90}$ Judge Pettine asked the officers to view their role in a positive manner, and explained that they were part of a "very challenging experiment" that could "serve as a model for prisons throughout the country". ${ }^{91}$ While this was an admirable task, and Judge Pettine stated he understood the problems that his ruling would create, he clearly did not anticipate the hostility and confusion that this ruling would incite due to his lack of knowledge regarding the innermost workings of a prison system. ${ }^{92}$ Officers' authority was already minimal at best, and they viewed this new interference and encroachment upon their already diminishing authority within a hostile and dangerous working atmosphere.

\footnotetext{
${ }^{89}$ Randall Richard, “Judge Faces ACI Guards on New Rules,” The Providence Journal, August 4, 1970, 1. ${ }^{90}$ Ibid.

${ }^{91}$ Ibid

${ }^{92}$ Ibid.
} 
The year 1970 was a very active year as it not only kicked off the beginning of the judiciary's prison reform efforts in Rhode Island but also began the era of the Howard administration at the ACI. Francis Howard, previously a Massachusetts parole supervisor, took over the post from John Sharkey, who was interim after Harold Langlois stepped down in June of the year before. Sharkey, while performing admirably in light of the circumstances, had been both acting warden and assistant director of the state Department of Social Welfare (for correctional services) at the same time. Many looked to the Howard administration to bring much needed change and to restore order and "calm" within the institution. ${ }^{93}$ Howard professed himself to be of a reformist school of thought, and yet also expressed a desire to "firmly" deal with the small faction of hardcore prisoners who were creating turmoil and destruction. ${ }^{94}$ Correctional officers, themselves, had reason to be optimistic as Howard had formerly been an officer and was also president of the Massachusetts State Prison Employees Union for some time ${ }^{95}$ However, this administration would be characterized by its continuation of the same old ways.

Howard's path of action was to create "a series of innovative programs to make inmates' life as close to that outside the walls as possible". ${ }^{96}$ Initially this path seemed promising as a very basic adult education program and job training courses were instituted at the ACI weeks after Howard's appointment. ${ }^{97}$ While programs were indeed necessary to help change the conditions within the prison, funding for them

\footnotetext{
93 “Mass. Lawyer is New ACI Warden,” The Providence Evening Bulletin, March 13, 1970, 1.

94 Ibid.

95 Ibid.

${ }^{96}$ David Donnelly, “New Warden to Seek Help of Ex-Inmates,” The Providence Evening Bulletin, March 30, 1970, 1.

97 “State Offers Education to ACI Inmates,” The Providence Journal, June 5, 1970, 10.

“ACI to Offer New Job-Training Courses,” Providence Evening Bulletin, June 12, 1970, 28.
} 
would prove to be problematic. He also sought the advice of ex-imates who were familiar with the system. However, he did not seem to find it necessary to spend as much time in consulting with the officers on the state of the prison. ${ }^{98}$ This administration would fail to open up lines of communication with those who were doing the work to maintain the security of the facility and undertook the risks that the facilities presented on a daily basis. However, Howard did argue for an increase in the pay scale of the correctional officers. He believed that this would improve the quality of the workers that the prison was hiring. Also, he emphasized the role of the correctional officer as a "front-line social worker" and stressed the job required more than just the skills of a guard, it required skills in communication and behavior management. $^{99,100}$

While advocates for the prisoners were called to action on the political scene and the press hailed Warden Howard as the catalyst for change, it was clear that nobody was advocating for or supporting the officers. The representation they had was inadequate. While it was clear that there were many issues that the prison had, that needed to be addressed for the sake of everyone involved, there were many methods for solving the dilemma. Unfortunately, in the meantime, the officers had become "demoralized" and desperately needed support from the administration that

${ }^{98}$ Ibid.

${ }^{99}$ Robert Baldwin, “ACI Beginning to Put Emphasis on Rehabilitation,” The Providence Journal, May 17, 1970, N27.

${ }^{100}$ Defining the nature of work for correctional officers is a matter that is still debated to the present day. Lt. Ken Rivard (grievance chair), in a 2010 letter to the editor of the Providence Journal defines the term "prison guard" as derogatory and explains that it takes away from the professional nature of the job. He feels the term "correctional officer" is better suited to the nature of their work and encompasses the ten weeks of training, extensive background checks, physical fitness requirements, psychological exams, and educational requirements (college degrees) that the officers must satisfy to be competent for the nature of the job. The expectations correctional officers are required to meet and the nature of the work has changed over time, as the goals of the prisons have changed to become more rehabilitative. Ken Rivard to Richard C. Dujardin (Providence Journal), August 2, 2010, RIBCO archives (Personal collection of Ken Rivard), Rhode Island Brotherhood of Correctional Officers, Rhode Island. 
they were not receiving. ${ }^{101}$ The AFL-CIO (under which AFSCME was organized) dealt with a variety of issues in the state of Rhode Island at this time. First and foremost, they were in opposition to a bill that would allow 15-year-olds to work instead of attending school. They believed that this would decrease the amount of jobs available to the adult population in a more difficult job market. ${ }^{102}$ They also were also working on gaining an increase in the pensions for all state employees. ${ }^{103}$ While this was beneficial to all workers, correctional officers included, there were a variety of other issues that the officers needed to be addressed that the union would not have the time or resources to delve into, due to the sheer amount of people it represented. The frustrations of the officers were mounting as tensions within the prison escalated and were left unresolved, and these frustrations would manifest themselves at the end of the year, as they demanded representation that would support them and provide a more effective path of action to improve their conditions.

On August 17, 1970, about forty guards stormed the office of Warden Howard. They were clearly aghast at the lack of support that they were receiving from the administration and had "reached the breaking point” of their frustrations. ${ }^{104}$ They demanded that "certain changes would have to be made within a week" or they would “start applying pressure". ${ }^{105}$ Union officials, of the AFL-CIO, assured the warden that this was not a union matter. ${ }^{106}$ Officer Louis Gallucci, spokesperson for the officers,

\footnotetext{
${ }^{101}$ William Laurie, Interview with the author, August 3, 2011.

102 "Prisoner Work Bill is Passed by the Senate," The Providence Journal Bulletin, April 29, 1970, 37.

${ }^{103}$ Ibid.

104 “ACI Guards Demand Change in Interview with the Warden,” The Providence Journal, August 18, 1970, 45.

${ }^{105}$ Ibid.

${ }^{106}$ Ibid.
} 
explained to a reporter that action needed to be taken and that the press should expect some "fireworks" on the following Monday, if nothing changed. ${ }^{107}$

In a meeting on August $19^{\text {th }}$, officers requested some very specific changes. The first was to put into place "modified procedures to control the inmates”, including screen doors on workshop doorways and more officers present during the inmate meals in the dining facility. ${ }^{108}$ Secondly, officers requested more training and uniforms for newer officers in a timelier manner. ${ }^{109}$ Thirdly, they expressed frustration over the rulings of Judge Pettine, due to the fact that it made the officer's job "a lot more complicated". ${ }^{110}$ Many felt that these procedures got in the way of the enforcement of order, as this greatly increased the amount of bureaucracy and paperwork needed for every action on the part of the officers. Lastly, the officers asked that the vacated job positions be filled to bring their ranks up to "full strength”. ${ }^{111}$ The union officials of the Local 114 American Federation of State, County, and Municipal Employees made an extra effort to insist that they did not back the officer's actions or complaints in these matters. ${ }^{112}$ The officers withdrew their threat of wildcat action based on the apparent willingness of the administration to take action. ${ }^{113}$ Money and manpower were proving to be problematic, yet the officers were content with opened pathways of communication and professional discourse.

\footnotetext{
107 Ibid.

108 "Guards Air Problems with Officials at the ACI,” The Providence Journal Bulletin, August 20, 1970, 30.

109 Ibid.

${ }^{110}$ Ibid.

111 Ibid.

112 Ibid.

113 “Guards, Officials at ACI Agree to Daily Meetings,” The Providence Journal, August 21, $1970,34$.
} 
As a result, the warden pledged to hire thirty more guards. ${ }^{114}$ This would allow more people to be trained (as this required substitutes to stand in their place) and would also help in terms of security during the meals in the dining areas, where inmates were gathered in mass. Many officers were working 18 hour shifts. ${ }^{115}$ In a ten week period, overtime payments totaled up to $\$ 84,451$. $^{116}$ The warden recognized and publically acknowledged the psychological toll that this great amount of overtime was taking on the officers, in the form of "impaired judgment" and "low morale". 117 Howard also acknowledged the on-going battle between the philosophies of prison management and felt that, at the end of August 1970, the ACI's moment of truth had come. He explained the need for money if they were going to run a more rehabilitative facility. ${ }^{118}$ The warden and the Providence Journal writers suggested that the pay scales of the officers needed to be raised, to decrease the need for overtime among the officers and to attract more candidates to the dangerous job. ${ }^{119}$

Of course, as to be expected in state politics, Republican party members charged the governor's office (a Democratic administration) with failing to provide adequate resources to the ACI. ${ }^{120}$ A Republican task force was created to investigate the conditions at the prison. This pattern would be repeated time and again. They pointed to the clear need for more officers and they also pointed to the large amount of money being spent in overtime pay. This issue over overtime pay would be a hotbed issue, particularly in the 1980s, however it has its roots at the beginning of the 1970's.

\footnotetext{
${ }^{114}$ Robert Baldwin, “ACI Needs More Guards,” The Providence Journal, August 23, 1970, N1.

${ }^{115}$ Ibid.

${ }^{116}$ Ibid.

${ }^{117}$ Ibid.

${ }^{118}$ Ibid.

${ }^{119}$ Ibid.

120 “GOP criticizes Licht on Personnel at ACI,” The Providence Journal Bulletin, August 26, 1970, 43.
} 
While this political bickering often times intruded on actual progress being made, it served at this juncture to suit the needs of the officers quite well. Warden Howard responded negatively to these charges and recognized the need to keep the ACI out of "partisan politics" in asserting that it would hinder the growth and development of the institution. $^{121}$

As of November 1970, the budget of the ACI increased from \$2.4 million to \$3.6 million. ${ }^{122}$ Warden Howard pointed to the harsh working conditions for correctional officers as a dire situation that required immediate relief. He pointed out that officers were regularly working seven days a week and often more than eight hours a day. ${ }^{123}$ He stated:

"[Correction officers] cannot carry the extreme pressures of this type of sustained overtime work without paying heavy physical and psychological penalties. Such penalties are already being paid and deterioration eventually will show."124

He reiterated the correlation between money and change. Without increased funds, the institution would revert back to "a repressive Alcatraz-type situation”. ${ }^{25}$ He also explained that compliance with the judicial orders of Judge Pettine required additional staff and manpower. ${ }^{126}$

However, despite these promising developments (regarding the increased budget and advocacy for the officers on the part of the administration), the officers

\footnotetext{
121 "Warden Scores GOP's 'Partisan Politics' in Attack on ACI,” The Providence Journal Bulletin, August 27, 1970, 33.

122 “ACI Budget Up \$1.2 Million,” The Providence Journal Bulletin, November 12, 1970, 1.

${ }^{123}$ Ibid.

${ }^{124}$ Ibid.

${ }^{125}$ Ibid.

${ }^{126}$ Ibid.
} 
still were left with the problem of representation. Similar to many workers of the 1970’s, they were very dissatisfied with their labor organization. AFSCME had become too large to properly meet their needs or address their concerns. In a prison environment, the needs of the officers can be a matter of safety and often a matter of life or death. Volatile and extreme situations required immediate attention and action. If a job action was necessary, the officers could not waste precious time waiting for their union to address the matter through the proper bureaucratic channels.

Many workers of the 1970's were echoing the same sentiments: they were all the "forgotten man". ${ }^{127}$ Overall, the labor movement created a kind of "national consciousness through strikes, popular culture, voting booths, and corporate strategy."128 The goals of the labor movement included creating more humane conditions and being treated with dignity. ${ }^{129}$ Yet, administrators and management did not count the voice of the workers into the decision-making process. Those who performed the jobs on a daily basis were not counted as experts, and were largely left frustrated and overlooked. Historian Jefferson Cowie describes the labor scene best in stating:

“They [the workers] fought with supervisors on the line, clogged up the system with grievances, demanded changes in the quality of work life, walked out in wildcat strikes, and organized to overthrow stale bureaucratic union leadership.",130

\footnotetext{
${ }^{127}$ Cowie, Stayin' Alive: The 1970's and the Last Days of the Working Class (New York : New Press, 2010), 3.

${ }^{128}$ Cowie, Stayin’ Alive, 2.

${ }^{129}$ Cowie, Stayin' Alive, 3-7.

${ }^{130}$ Cowie, Stayin' Alive, 7.
} 
This is not only an accurate description of the actions of workers throughout the beginning of the 1970's, but also an exact description of the workers that would soon form the Rhode Island Brotherhood of Correctional Officers during the same time. However, this group of workers was not an average group of workers. These officers were not just struggling for improved working conditions, but also were fighting for their own safety and survival among hardened criminals. They had a startling degree of unity and cohesiveness that was impressive even for that time period in labor history. They were more invested, than the average worker, in ensuring that their actions were successful.

During this same time, within the political realm, standing up to public sector unions “became the litmus test of a politician’s sense of fiscal responsibility”. ${ }^{131}$ The public questioned spending and, at least within the public sector, it no longer became feasible to replace striking workers. The distance between union members and the rest of the American public grew and both groups lost touch with one another. ${ }^{132}$

An editorial in the Providence Journal, written by a Rhode Islander, summed up the mood of the times in the following manner:

"Is the Nixon administration testing the patience of the taxpayers in this country, wondering how much longer they will keep their mouths closed, before rising up in arms? It is bad enough that people are out of work. They are lucky to get home safely...”133

\footnotetext{
${ }^{131}$ Cowie, "Portrait of the Working Class," 98.

132 Cowie, "Portrait of the Working Class", 99.

${ }^{133}$ Emile Trahan, "When in the Course of Human Events...," The Providence Journal Bulletin, December 18, 1970, 30.
} 
Workers and Americans were faced with a bleak picture that they desperately hoped to change. This was a time of tension and struggle, but also a time of potential.

This decade is viewed by some labor historians as "a bridge between eras". ${ }^{134}$ For most unions, while the first half of the era (within the early 1970's) suggested a great amount of progress and promise for workers, the second half (the latter part of the 1970's into the 1980's) was disappointing in its regression and recognition of limits. By independently organizing, the Rhode Island Brotherhood of Correctional Officers were able to overcome the struggles that most unions encountered throughout the 1970's and into the conservative years of the 1980's. They were able to take more immediate action and were also able to control a message to send to the general public, which would help to gain them increased funds and support for various issues. This union survived while other unions crumbled and created a public sector labor union that would withstand politics, financial burdens, and challenges for years to come. However, they were unaware that what they were creating was unique and would be so successful, at the time that they were creating it. They were merely fed up with the lack of support and the conditions they encountered every day, and resolved to unite and fix their problems, one day at a time.

On December 17, 1970, 116 correctional officers in the state of Rhode Island took a stand, along with many other workers of the same era. ${ }^{135}$ They resigned from the Local 114 of the American Federation of State, County and Municipal Employees to gain “the recognition and bargaining power” they felt that they lacked. ${ }^{136}$ They admonished the "quality of representation" that they had previously received and

\footnotetext{
${ }^{134}$ Cowie, "Portrait of the Working Class," 93.

135 “ACI Guards Eye New Labor Union,” The Providence Journal Bulletin, December 18, 1970, 29. ${ }^{136}$ Ibid.
} 
decided to chart a new path forwards. ${ }^{137} 184$ out of 240 employees previously petitioned the Rhode Island State Labor Relations Board for a new election (in October 1970). ${ }^{138}$ The officers who resigned believed that, in forming their own union, they would eventually push the Rhode Island State Labor Relations Board to hold an election, and they were correct, as they received an election in 1971.

John Galligan, who would be the first president of RIBCO, stated: "Most of the correctional officers feel that by binding together, the state will be forced to recognize them." 139 He also stated that he expected the workers to "press ahead" with their new union, "regardless of how the board ruled." ${ }^{140}$ It is clear that workers felt a sense of commitment and unshakable resolve, which would be helpful to them in the coming decades.

This period which led to the creation of RIBCO charted the path of a group of workers who decided to go against the grain and take matters into their own hands. By choosing to represent themselves, these workers were accepting responsibility for their working conditions and took an active role in fomenting change. This set the stage for a unique method of approaching unionism, which would be very successful in later years. The tenacity, innovativeness, and solidarity exhibited by these workers in the early years, carried forth for the next decade to come.

\footnotetext{
${ }^{137}$ Ibid.

${ }^{138}$ Ibid.

${ }^{139}$ Ibid.

${ }^{140}$ Ibid.
} 


\section{CHAPTER 4}

\section{The Formative Era}

The 1970’s was an era in which society moved in a new direction. ${ }^{141}$ It was a time when the New Deal era began to fall apart. ${ }^{142}$ The nation began to lose its sense of direction and purpose. Jefferson Cowie characterizes the decade as a "troika of disasters” in referring to the president's resignation, the loss of faith in the national government, and the fall of Saigon, as well as the economic disasters that resulted from inflation, oil shocks, and deindustrialization. ${ }^{143}$ America entered an age of “stagflation”. Wages, productivity, and output all dropped "sharply” and recessions were frequent and more debilitating as time went on. ${ }^{144}$ Economically, the common worker struggled while corporate executives earned twenty times the amount a common worker would earn. Skills that were crucial to the ever expanding American military war machine were not easily transferable to the consumer market, leaving many without marketable skills in the job market. Economic hardship and social inequality characterized this decade, and for many, this was not a time in their lives that they would like to revisit. The general mood of the nation became pessimistic. ${ }^{145}$

Within the workplace, the expanding discussion of civil rights created many legal difficulties for companies. Inflammatory issues throughout the 1970's included: workplace safety, health, the equitable treatment of women, and the equitable

\footnotetext{
${ }^{141}$ Cowie, Stayin Alive, 11.

${ }^{142}$ Ibid.

${ }^{143}$ Cowie, Stayin Alive, 12.

${ }^{144}$ Who Built America, The American Social History Project, Worth Publishers, New York, NY, 2000, 683.

${ }^{145}$ Who Built America?, 684-686.
} 
treatment of African Americas. ${ }^{146}$ The AFL-CIO found itself conflicting with Civil Rights legislation in that they traditionally restricted access to craft unions to maintain bargaining power and this, in reality, discriminated against minorities (with regard to race and gender). While labor endorsed these laws and fundamentally agreed with the principles contained therein, Title VII helped to destroy their solidarity as a bargaining unit. The economic shocks of 1970's were crucial in that they prevented the federal government from being in an economic position to be able to interfere on behalf of labor. ${ }^{147}$ Overall, workers had to learn to fight their own struggles because the cavalry was not coming to advocate on their behalf, as they had been known to do in the past. Clearly, the tides were turning and the situation became more extreme.

Throughout this formative era, RIBCO fought to protect the safety of its workers, bargain for better wages and benefits, and gain respect within the realm of public discourse. RIBCO engaged in a series of effective job actions and also utilized the press to communicate to the general public. By the end of the decade, the union managed to improve relations with management, increase wages, and build a public image that would be crucial in years to follow.

\section{1: The Start of a New Era}

Thus, as the new year of 1971 began, it is not surprising that the newly formed Rhode Island Brotherhood of Correctional Officers began with a series of job actions to demand the changes it required. Throughout the year, the union focused on trying to re-establish the authority of the officers, increase their pay scale, and obtain greater involvement in managerial decisions. They pushed for a uniform policy and set of

\footnotetext{
${ }^{146}$ Who Built America?, 687.

${ }^{147}$ Melvyn Dubofsky, The State \& Labor in Modern America (Chapel Hill : University of North Carolina Press, 1994), 195-238.
} 
enforceable directives from the administration to eliminate confusion. The officers were successful in gaining some recognition on the part of management and also gained more authority within the public sphere and established a presence within the public forum (either in the legislature or within the press).

The union undertook a variety of actions to establish themselves as an effective labor organization and also to increase their public exposure. First and foremost, union leaders continuously argued in the public forum for an increase in the number of officers on staff to increase security. This would greatly improve their working conditions. The union argued for a training program would help new officers adjust to the working conditions within the prison and would help the ACI retain employees. Pension reform would also help to attract higher caliber workers. Officers also argued for more shop-floor control both in the public forum (including in the newspapers as well as before the legislature) and in interactions with the administration. They felt that management did not take into account the practical aspects of implementing their own policies and directives and felt that the officers should have greater voice in the creation of a standard policy.

Internally, RIBCO struggled with all of the same problems all new unions face. The union needed to win the hearts and minds of its members by demonstrating that union organization did work. As with many unions of the 1970s, the union leadership had to contend with its rebellious rank and file. A small faction of officers initially did not agree with the majority and pushed for more extreme action. Union leaders were hesitant to act too aggressively, for fear of damaging relations with the administration permanently. The union also had to win the support of the public (or at least some 
degree of legitimacy) as it was a public sector union, at the mercy of the general population. With the revolt at the Attica Correctional Facility in September and a disturbance within the ACI itself in October, the union did manage to elicit some sympathy and gain some public support.

On January 18, 1971, the morning shift at the maximum security facility refused to report to work until they had been "promised tighter controls over inmates". ${ }^{148}$ This marked a stark contrast with the previous interactions between officer leaders and the administration. This was a united job action, in support of officer safety and stricter administrative regulations. They were responding to a situation that occurred the night before during a Jaycee Chapter dinner. A guard had been assaulted during the dinner when he stopped a visitor from bringing a bottle of liquor into the facility. ${ }^{149}$ They were fearful because the prisoners had progressed from name calling to assaulting the officers and the officers. The officers were granted a search in the maximum security section for contraband in response to the change in the atmosphere. ${ }^{150}$

The officers now had a much quicker, and more effective response to changes in their work environment that they were opposed to. Until the administration handled the situation, they would find themselves in a very difficult and dangerous predicament. This was a tactic that was certain to bring immediate attention and remedy to their concerns. The most immediate change was that four inmates were

\footnotetext{
148 “Prison Guards Refuse to Work, Receive Pledge,” The Providence Evening Bulletin, January 18, $1971,1$.

${ }^{149}$ Ibid.

${ }^{150}$ Ibid.
} 
transferred to the Cedar Junction prison, located in Walpole, Massachusetts. ${ }^{151}$ Upon performing the search of maximum security, the officers obtained several knives and "other weapons" that were "smuggled in or stolen". ${ }^{152}$ In addition to this, the warden agreed to a new plan for the dining hall system, keeping more men on duty at one time within the dining hall. ${ }^{153}$ Also, the man who was attempting to bring liquor into the prison was charged. ${ }^{154}$ They also discovered, upon further investigation, that the inmates had managed to smuggle in additional wine and whiskey. Directly after this, Warden Howard banned parties of inmate organizations. ${ }^{155}$ It was clear that the officers had picked a poignant disturbance to make their case and they had received a quick and constructive response to their concerns.

Directly after this, inmates proposed four bills to the Senate in a legislative forum sponsored by the ACI Jaycees and the prison newspaper, “The Challenge”. The bills would allow those serving life sentences to attend work or school outside of the prison, would stop the use of solitary confinement, would establish a board to help represent African American inmates at the administrative level, and would grant furloughs to prisoners deemed "trustworthy" ${ }^{156}$ While racial representation was the most admirable aspect of these proposed laws, there were some glaring difficulties it would present regarding the security issues involved with allowing "lifers" to participate in activities outside of the grounds. It would require an increase in manpower and observation, and the precedent of work release was one that did not

\footnotetext{
151 “ACI Transfers Four Prisoners After Assault,” The Providence Journal, January 19, 1971, 1.

${ }^{152}$ Ibid.

${ }^{153}$ Ibid.

${ }^{154}$ Ibid.

155 “ACI Warden Bans Parties of Inmate Organizations,” The Providence Journal, January 20, 1971, 16.

156 “ACI Inmates Propose 4 Bills to R.I. Senators,” The Providence Journal, February 16, 1971, 31.
} 
support the inmates’ cause. In 1970 alone, there were 30 escapes. ${ }^{157}$ A good percentage of the escapes from the prison, in 1970 and previous years were due to inmates who impulsively escaped on work release. ${ }^{158}$ Also, abolishing solitary confinement would be abolishing a mechanism of discipline that the prison sorely needed. ${ }^{159}$ Again, there was a direct conflict between the goals of security and rehabilitation, and the officers would be expected to pick up the slack, if the legislation passed. This also helps to demonstrate the great degree of power that the inmates had within the political system and among the powers that be.

Legislation was then brought before the House of Representatives regarding a few major points: a setting of minimum standards for food, clothing, exercise, and hygiene, medical checkups, and the abolishment of the "hole" (a bare cell used for punitive confinement). ${ }^{160}$ A couple of months later, the Senate passed a furlough bill allowing unescorted furloughs under certain circumstances and also for interviews, training, education, or health care not available at the ACI. ${ }^{161}$ These bills were meant to remedy the problems regarding rehabilitation, yet they merely staunched the flow of the actual problem. The prison still needed a substantial increase in funds to make the rehabilitation goals a reality. Only with a substantial increase in funds would the system be safe and also support rehabilitation. Unfortunately, it would take a series of

\footnotetext{
${ }^{157}$ David Donnelly, “Escapes Test Rehabilitation,” The Providence Journal Bulletin, December 24, 1970, 1.

158 “2 ACI Inmates Escape Detail,” The Providence Journal Bulletin, March 14, 1970, 2.

“2 ACI Prisoners Sought After They Disappear,” The Providence Journal, June 2, 1970, 13.

"Prisoner Walks Away from ACI While At Work," The Providence Journal, July 28, 1970, 6.

“Inmate Strolled Off, Count at ACI Shows,” The Providence Journal, August 8, 1970, 18.

“Three Convicts Flee Maximum Security at ACI,” The Providence Journal, October 26, 1970, 1. David Donnelly, “Escapes Test Rehabilitation,” The Providence Journal Bulletin, December 24, 1970, 1.

159 “ACI Inmates Propose 4 Bills to R.I. Senators,” The Providence Journal, February 16, 1971, 31.

160 “New Standards Urged for the ACI,” The Providence Journal, March 31, 1971, 24.

161 “Senate Passes Furlough Bill for Prisoners,” The Providence Journal, May 20, 1971: 9.
} 
escapes and violence over the next decade to make the legislative body of the state of Rhode Island and the public realize that only an increase in funding and serious improvements to the facilities would bring the much needed change to this prison system.

On the labor front, the ACI guards were fighting a difficult battle. While legislation was being passed in favor of the prisoners needs, the legislation regarding pensions did not favor the officers. On July 6, 1971, sixty officers on the morning shift refused to report to duty. ${ }^{162}$ They were frustrated with the Senate's "failure to act" on an improved pension plan. ${ }^{163}$ The officers decided to "follow our president" [sic.] and ended the work stoppage, but they clearly made their displeasure known. The bill would have allowed retirement at age 50 with twenty years of service, and at that time the retirement age was 58 with thirty five years of service. ${ }^{164}$ Newly elected President of RIBCO, John Galligan, poignantly stated, in support of the bill:

“People don’t realize that it's as hard for the guards as it is for the inmates. The inmates get a life sentence and they're up for parole after 10 years. We get a life sentence and it's good for 35 years.”165

Typically, in most other states (in the past and presently), a system of earlier retirement for corrections personnel was instituted due to the nature of the work. The guards clearly believed that they had fallen on the wrong side of the political game regarding workers and prisoners, and were not going to let it continue.

\footnotetext{
162 “Protest Stalled Pension Bill,” The Providence Journal Bulletin, July 6, 1971, 1.

${ }^{163}$ Ibid.

${ }^{164}$ Ibid.

${ }^{165}$ Ibid.
} 
This was a test of cohesiveness for the Brotherhood. In returning back to work, many felt that their executive board had not taken a hard enough stance. The new organization was barely six months old and was withstanding its first test against internal factions. John Galligan, the president, opted to take a course of action that was less extreme and would not endanger the "security of the prison or the health and safety of the community,” because a prolonged absence of the officers could mean an increased chance of rioting. ${ }^{166}$ Many officers felt that they could not take the legislators at their word and needed to take a more aggressive stance. This faction ripped up their membership cards in a display of anger. ${ }^{167}$ Galligan referred to the union as "a disgruntled organization". ${ }^{168}$ However, as a whole the organization stayed together and presented a case to the legislators. They produced a list of thirty two men who were suffering from "heart attacks, hypertension, high blood pressure”, ailments brought on or worsened by stress, in an attempt to explain why a lower retirement age was necessary in this line of work. They also listed guards who had been beaten, stabbed, and one who "had scalding water thrown in his face". ${ }^{169}$ Even if they did not all agree on the path of action, for the most part, they all recognized that unity would be their best chance of making a change. It did work in this case, as they got the legislation passed. However, more importantly, they survived this internal crisis and united for future endeavors.

At the same time, the officers now found that they had a stronger voice in the public arena, and a larger audience with regard to reporters. In a close up profile of

\footnotetext{
${ }^{166}$ Lester Boyd, “ACI Guards Reluctantly Return to Work,” The Providence Evening Bulletin, July 7, 1971, 31.

167 Ibid.

${ }^{168}$ Ibid.

${ }^{169}$ Ibid.
} 
Warden Howard, in which he tried to inform the public of his position on matters of importance and just how much of a struggle he was encountering in making changes, there was also a good degree of officers’ opinions contained within the article. ${ }^{170}$ Warden Howard appeared to put a good majority of the responsibility for rehabilitation on the officers in stating: "I think that when rehabilitation is done properly, it will be done by the correctional officers...” “... We have some officers doing this right now...” “...It’s too bad there aren’t more."171 Ronald Brodeur, who was an officer at that time, explained the frustration of the officers in response to attitudes like this in stating: "How can you hold us accountable when you are not going to tell us what it is we need to be accountable for?”,172 One officer, when asked how the rest of the officers felt about the warden, explained that he thought they believed that the warden was not exercising enough control over the inmates. ${ }^{173}$ Howard was focused on instituting a training program for the officers that would "include instruction in basic corrections, practices as well as the philosophies behind modern penology". ${ }^{174}$ While this sounds admirable, the push for a training program came from the officers themselves, not any state officials. ${ }^{175}$ The officers were in need of some kind of consistent policy that would be enforced by all, as to avoid confrontation with inmates and administrators. ${ }^{176}$ This is indicative of the path that corrections officials would embark on for the next few years: a path in which the

\footnotetext{
${ }^{170}$ Robert Baldwin, “Some Wardens Are Prisoners Too,” The Providence Sunday Journal, September 12, 1971, M30.

${ }^{171}$ Ibid.

${ }^{172}$ Ronald Brodeur, Interview with the author, March 17, 2011.

173 Ibid.

${ }^{174}$ Ibid.

${ }^{175}$ Ken Rivard, Interview with the author, March 29, 2011.

${ }^{176}$ Ibid.
} 
administration and the workers would confront one another in the public forum (the newspapers) to gain the support of the public.

However, the public, unfortunately, would not be moved to action without incentive. Usually this incentive was in the form of safety, and action was taken in response to a perceived threat. The first, in a series of perceived threats to the people of Rhode Island (and the American public in general), came in the form of the rebellion at Attica Prison, New York. Thirty-seven men (twenty eight prisoners and nine hostages) were killed in this bloody confrontation. ${ }^{177}$ One thousand state troopers, sheriff deputies, and correctional officers stormed the prison and retook it after a tense five day standoff, involving the taking of hostages (officers and civilian workers) and capturing of cellblocks. ${ }^{178}$ An article within the Providence Journal contains pictures of the storming of the facility and the disaster contained within. ${ }^{179}$ There is also a particularly moving picture of a surviving hostage who was embracing his wife after his release. He was saved by an inmate who only pretended to cut his throat. ${ }^{180}$ These images served to make the confrontation less abstract in the minds of the citizens of Rhode Island. With all of the turmoil at the ACI, it seemed that an insurrection was inevitable and would affect the lives of human beings with families and loved ones.

This would make the situation even more difficult for Warden Howard, who was pushing for the public to spend money on rehabilitation. The warden tried to tie this incident to the need for rehabilitation. He further alarmed the Rhode Island

\footnotetext{
177 “Prison Retaken; At Least 37 Die,” The Providence Journal, September 14, 1971, 1.

178 Ibid.

179 Ibid.

180 Ibid.
} 
citizens by informing them that this unrest was of a national nature and that he thought it was a "national type of movement, this revolutionary group, agitating group.”181 Again, this opened up the discussion involving prison conditions, with regard to the demands of the inmates within the Attica prison facility. ${ }^{182}$ However, a critical shift occurred in the public discourse: the danger that the officers faced every day was now put front and center in the public discourse. Workers, who were victims of prison violence now had names and faces to put to the names. Officers were now viewed as human beings, with lives and with families and loved ones. ${ }^{183}$ More frequently, comparisons between the Attica State Prison and the ACI were drawn, helping to further intensify the anxieties of the public. ${ }^{184}$ As unrest spread to the Cedar Junction prison facility in Walpole, and Warden Howard stated that he anticipated unrest at the ACI, the citizenry of Rhode Island became extremely alarmed. ${ }^{185}$ While this massacre was a tragedy for everyone involved, it served to quantify the danger for the average citizen who had never been within prison walls and had no conception of the degree of peril and fear these officers encountered on a daily basis. Furthermore, the public would be more willing to provide resources to support the officers, so that the violence and danger would not spill out into the surrounding communities. It was clear that, if things did not change, the blood of these victims, these correctional officers, would be on the public's hands.

\footnotetext{
181 "Unrest at Attica Termed National,” The Providence Evening Bulletin, September 14, 1971, 25.

182 "Attica Revolt,” The Providence Evening Bulletin, September, 14, 1971, 28.

${ }^{183}$ Joseph Lelveld, “Attica Guards' Families React to Report Hostages Were Shot,” The Providence Evening Bulletin, September 15, 1971, 37.

184 “ACI Called ‘a Jungle’ by Correction Official,” The Providence Evening Bulletin, September 16, 1971, 27.

"Conditions at ACI Likened to Those at Attica," The Providence Evening Bulleting, October 1, 1971, 29.

185 “Warden Expects Unrest at ACI,” The Providence Journal, October 7, 1971, 3.
} 
Providence Journal writer Paul Giacobbe summed up the paradoxes of the early 1970’s nicely. He referred to it as

"an age when the violence of Atticas and Soledads clash with quieter calls for prison reform, and an angry society's reaction to crime in the streets is challenged by a demand for increased civil rights; running a prison is an unenviable job combining the problems and headaches of a police chief and a college president." ${ }^{186}$

The larger question was going to be how to compromise between reform and safety, in addition to how to fund the changes. John Sharkey, head of correctional services, was prophetic in viewing Attica as a catalyst for the major changes to come. ${ }^{187} \mathrm{He}$ proposed the destruction of maximum security, and the building of a few new, smaller buildings in its place. ${ }^{188}$ A frustrated Warden Howard appealed to the state budget panel and to the people of Rhode Island in asking: "Do the people of Rhode Island want an 'Alcatraz-type' facility or efforts to rehabilitate?”189 An editorial in the Providence Journal made certain to reiterate the crucial point made by Warden Howard that “the state correctional institutions don't belong to a state bureaucracy but to the people of Rhode Island." 190 It went on to say: "The public cannot wash its hands of what goes on behind prison walls." ${ }^{191}$ The fate of the correctional officers hinged upon the mercy of the public.

\footnotetext{
186 “Prison Reform Delicate,” The Providence Journal Bulletin, November 10, 1971, 1.

${ }^{187}$ Ibid.

188 "Replacing ACI Building Urged,” The Providence Journal, November 17, 1971, 1.

189 “Do People of R.I. Want 'Alcatraz-type' Facility or Efforts to Rehabilitate?,” The Providence Journal Bulletin, November 16, 1971, 1.

190 "Prison Reform," The Providence Journal, November 13, 1971, 21.

${ }^{191}$ Ibid.
} 
The war of words in the Providence Journal continued: on one side the administration and the inmates, and on the other, the officers. One article, titled ““Experts Tell of Life Inside ACI: Prison Found Not Correctional,” gave a series of interviews with inmates who described the conditions and also insinuated some abuse by the officers. ${ }^{192}$ Inmates who had been to other facilities referred to the ACI as a “summer camp” while others disagreed. ${ }^{193}$ In direct response to the piece regarding Warden Howard and the piece on the inmates, the officers put forward a response in an article detailing the nature of their work and responsibilities, as well as their daily stress. ${ }^{194}$ President Galligan explained that recruitment and retention were their largest problems. ${ }^{195}$ Another officer exclaimed, with frustration: "Because of Pettine and Howard, we can’t do our job.”196 Again, the shortage of personnel was stated as a major cause of frustration, because this meant many officers were working seven days a week. Also, many were refusing promotions, in an attempt to retain seniority privileges which were not protected upon promotion. ${ }^{197}$ The Brotherhood reiterated that they would be sponsoring a bill that would establish a training program for new officers. John Galligan also demonstrated to a reporter, in the visiting room that contraband and drugs could easily be slipped to prisoners in the visiting room due to the lack of personnel hired to be on watch in the room (at that time, only one officer was posted in the visiting room). ${ }^{198}$ Pictures of individual officers on the job, helped to humanize their position. The reporter made an effort to explain how they were

\footnotetext{
${ }^{192}$ William Welt, “'Experts’ Tell of Life Inside ACI: Prison Found Not Correctional,” The Providence Sunday Journal, October 10, 1971, A1.

${ }^{193}$ Ibid.

194 "Prison Guards Work Long, Tense Hours," The Providence Sunday Journal, October 17, 1971, A 1.

${ }^{195}$ Ibid.

${ }^{196}$ Ibid.

${ }^{197}$ Ibid.

${ }^{198}$ Ibid.
} 
"struck by the vulnerability of the officers" in that "hundreds of inmates wander freely inside and outside the blocks, workshops, and yard, surrounding single, unarmed officers”. ${ }^{199}$ This paints a very different image from that put forth by the inmates, and helps to gain the officers sympathy in the eyes of the public. Unfortunately the mysterious aura of the prisons had been working against the officers who were doing a bulk of the work. With more press exposure and visitors to the prison, the officers were able to make their conditions accessible to the general public and give their grievances greater credibility and legitimacy.

A disturbance involving thirty inmates who were refusing to go back to their cells held up operations in the ACI on October 30, $1971 .^{200}$ This seemed to confirm the worst fears of the citizens of Rhode Island. Officers, as was now their pattern, refused to report to work for two hours until they had a meeting with a warden to discuss what would be done in response to the disturbance. In response, inmates were held in their cells all day the next day and remained under lockup the day after. ${ }^{201}$ Officers also requested that a printed set of "guidelines governing conduct of both prisoners and guards” be drawn up, as to create some consistency in enforcement. ${ }^{202}$ The union felt that officers should be more involved in this process of drawing up a guideline for conduct. Officers were also upset by the fact that they were told by the warden that there was no money to hire additional officers. ${ }^{203}$ The officers also argued for the creation of a list of prisoner infractions, which would help deter them from rebellious behavior and would also assist in the prisoner classification process. The

\footnotetext{
${ }^{199}$ Ibid.

200 "Versions Differ on Saturday's ACI Rebellion,” The Providence Journal, November 1, 1971, 1.

201 “ACI Officials Confer on Unrest,” The Providence Journal Bulletin, November 1, 1971, 1.

${ }^{202}$ Ibid.

${ }^{203}$ Ibid.
} 
administration disagreed with this policy, and viewed it as a throwback to the archaic policies of earlier decades. ${ }^{204}$ The officers were constantly appealed to as the group to make the reforms a reality, and yet were struggling to take responsibility within the prison. The administration was not allowing them to take responsibility, and yet often berated them in the press for not doing so. They were stuck within a losing situation and would struggle for some time to find a balance.

The administration did make some efforts to avoid new disturbances. On November 19, 1971, eleven inmates were transferred out to other institutions in a bold move on the part of the administration. ${ }^{205}$ This was in response to a plot to take guards hostage, similar to the situation in Attica. ${ }^{206}$ The inmates had been hiding weapons and also stockpiling food, enough for a few weeks. They were also attempting to take top prison officials hostage as well. ${ }^{207}$ Surprisingly, all officials deferred to the warden and his statements and refused to comment further until the governor confirmed the plot. ${ }^{208}$ While the press blasted Warden Howard for his policy of secrecy, this is the kind of leadership that would unite the prison and create a positive working atmosphere for all involved, instead of constant bickering in the public realm. $^{209}$

\footnotetext{
${ }^{204}$ Ibid.

205 “11 Prisoners Moved to Avert ACI Riot,” The Providence Evening Bulletin, November 19, 1971, 1.

206 “ACI Takeover Seizure of Guards Foiled,” The Providence Evening Bulletin, November 20, 1971, 1. ${ }^{207}$ Ibid.

208 "Licht Confirms Plot for Uprising, Hostages at ACI,” The Providence Evening Bulletin, November 24, 1971, 1.

209 "Secrecy at the ACI," The Providence Evening Bulletin, November 23, 1971, 22.

This would be short lived, as there was a highly publicized dispute between Warden Howard and John Sharkey (head of correctional services for the state Department of Social and Rehabilitative Services), in which Warden Howard threatened to quit if he had to follow a couple of unspecified directives from Sharkey.

Robert Baldwin, "Warden Says He May Quit In Operational Dispute,” The Providence Journal, January 13, 1972, 1.

“Gov. Enters ACI Dispute,” The Providence Evening Bulletin, January 13, 1972, 1.
} 
While major events were taking place regarding policy and safety, the union also had to band together on other labor issues at the end of 1971. Officers began to band together to challenge suspensions. They threatened job action over the suspension of John Kiley, who was suspended for taking too much sick leave. ${ }^{210}$ Unfortunately, Mr. Kiley was suffering from acute diabetes and was given a physician's certificate which stated that he was unable to work due to illness. ${ }^{211}$ While this is a smaller incident, it is crucial in demonstrating that, within a year, the Brotherhood was now bringing issues to the table that were sure to be ignored by a larger bargaining unit. Safety and policy were issues that benefited from an independently organized union, but other issues regarding employment and benefits could also be given the individual attention that they deserved. ${ }^{212}$ Overall, the year of 1971 served to bring unity through job action and strength under the strong leadership of John Galligan. The union survived its first tests of cohesiveness. As the union entered 1972, its members continued to adhere to the growing inclination towards “union militancy."213

\section{2: Responses to Attica}

The year of 1972 began with more measured goals which were all achieved throughout the year. The union advocated for five laws that would benefit the

\footnotetext{
“ACI Prisoner Groups Urge Support for Warden,” The Providence Sunday Journal, January 15, 1972, 12.

" $4^{\text {th }}$ Meeting Is Set About ACI Situation,” The Providence Evening Bulletin, January 19, 1972, 35. “ACI Warden, Official 'Resolve’ Dispute,” The Providence Journal, January 22, 1972, 13. 210 “ACI Guard Suspension Is Protested by Union,” The Providence Journal, December 7, 1971, 30. ${ }^{211}$ Ibid.

${ }^{212}$ Unfortunately Mr. Kiley made the issue null by not showing up for negotiations on his behalf. However, they officers were able to make the point that it should not be the amount of days taken, but the illness in question that should be considered in these matters.

“ACI Labor Dispute Apparently Resolved,” The Providence Journal, December 10, 1971, 25.

${ }^{213}$ Michael Harrington, “Union Militancy On the Rise,” The Providence Journal, January 29, 1972, 15.
} 
officers, and lobbied the legislature effectively to pass this legislation. Union leaders pushed for increased pre-service training as well as professional development incentives for those who were already employed by the ACI. They also sought to improve the contract by increasing their pay and gaining more benefits, at a level equitable with their counterparts in other states. Lastly, officer safety was always a priority, however the union did not need to argue as publicly for increased safety measures as the general public vociferously clamored for change in response to escapes and a hostage situation.

Many reformist-minded professionals, administrators, and legislators proposed multiple directions for change within the ACI, at the beginning of $1972 .{ }^{214}$ Three bills were pending in the General Assembly: one would allow prisoners who were serving life sentences to participate in a work-release program, one would create a three member African-American advisory committee, and one would allow unescorted furloughs. ${ }^{215}$ However, a very small article acknowledged the testimony given to a personnel subcommittee of the Governor's Citizens’ Action Council for the Adult Correctional Institutions by RIBCO president John Galligan. In this testimony, Galligan again stressed the overtime work that was actually needed to maintain an "equitable salary". ${ }^{216}$ He argued that officers were overworked and the quality of their work suffered as a result. Even more interesting was a meeting that was arranged by

\footnotetext{
${ }^{214}$ Robert Baldwin, “R.I. Prison System Assailed by Officials,” The Providence Sunday Journal, February 6, 1972, 1. Robert Baldwin, "Prison Reform Approaches Differ,” The Providence Journal, February 7, 1972, 1. ${ }^{215}$ Robert Baldwin, “ACI Warden Backs Prison Reform Bills,” The Providence Journal, February 15, 1972, 23.

216 "Union Head: Staff at ACI is Overworked, Underpaid,” The Providence Journal, February 15, 1972, 23.
} 
the union to lobby for five other bills that would benefit the correctional officers. ${ }^{217}$ In meeting with the state legislators, the officers were also asked their opinion on the other pending legislation regarding the reform bills. The officers gently expressed their displeasure with the work release plan for those serving life sentences, based on security factors. ${ }^{218}$ The five bills that were proposed for the benefit of the correctional officers involved: increasing the amount of retirement allowance, the inclusion of superiors officers and counselors in the retirement plan, providing incentive pay for those who continue their education in correctional work, providing pay for time lost due to an assault, and making it a crime to incite a riot or encourage violence that would lead to a riot. ${ }^{219}$ The work release bill was delayed so that a hearing could be held to weigh the pros and cons regarding the proposed legislation, subsequent to the discussion with the union. ${ }^{220}$ It was then returned to committee. ${ }^{221}$ John Galligan was also asked his opinion on the furloughs bill, in which he stated that the officers felt it should be restricted to minimum security inmates only. ${ }^{222}$ As a direct result of Attica, officers now had some sympathy among the legislators.

Officers were now also given a voice in hearings, such as the seminar conducted by an educational consulting firm under the Law Enforcement Assistance Administration. ${ }^{223}$ Workers now had a venue to voice their complaints and concerns regarding their lack of training and lack of professional development. They also gained an opportunity to discuss the inconsistencies that resulted from the lack of

\footnotetext{
217 “Work Release Plan for Lifers Opposed,” The Providence Journal, February 25, 1972, 23.

218 Ibid.

${ }^{219}$ Ibid.

220 “Work-Release Bill Delayed for Hearing,” The Providence Journal, February 26, 1972, 14.

221 “Work-Release Bill Returned to Committee,” The Providence Journal, March 2, 1972, 20.

${ }^{222}$ Robert Baldwin, “Little Support Given to ACI Furloughs Bill,” The Providence Journal, April 25, 1972, 30.

223 “Seminar for Guards at ACI Ends,” The Providence Evening Bulletin, May 8, 1972, 38.
} 
training and lack of a clear policy. ${ }^{224}$ Many explained that good workers left because of the discrepancies between what was taught in school and the reality of the conditions within the prison itself. ${ }^{225}$ After this, a report was generated and distributed to prison officials and reviewed by a ten man board. ${ }^{226}$ This served to raise the morale of the officers as workers, and also served to bring more attention to the hazards and confusion of the shop-floor environment. It also served to bring about immediate action. On June 12, the ACI began in-service training. ${ }^{227}$

Meanwhile, the administration proposed building a new prison complex, fashioned after the ideas of John Sharkey (with a good number of smaller buildings). ${ }^{228}$ They put forth halfway houses and probation as effective solutions to the ACI's growing list of problems. ${ }^{229}$ However, this was not enough. In the beginning of July 1972, The Citizens’ Action Council on the Adult Correctional Institutions received a harsh report condemning the ACI administration as being “weak and indecisive”, which was destroying chances of rehabilitation. ${ }^{230}$ It complained that the staff needed a central direction to follow so that they will know “exactly what the policies and programs are.”,231

With the mass criticism, the Department of Corrections opened its doors, under the new leadership of Anthony Travisano. Travisano announced his agreement with the philosophy of the report and stated: "We intend to develop a correctional

\footnotetext{
224 Ibid.

${ }^{225}$ Ibid.

${ }^{226}$ Ibid.

227 “ACI Starts In-Service Training,” The Providence Journal, June 13, 1972, 29.

${ }^{228}$ Robert Baldwin, "Proposed Prison Complex Too Big?,” The Providence Sunday Journal, May 14, 1972, C8.

${ }^{229}$ Ibid.

${ }^{230}$ Paul Kelly, “'State’s Correctional Systems Do Not Correct,” The Providence Evening Bulletin, July 5, 1972, 1.

${ }^{231}$ Ibid.
} 
philosophy which will take into account many of the positive recommendations.”232

The editors of the Providence Journal hailed Travisano as being the welcome breath of fresh air that the tired old ACI prison system desperately needed; the one who would fill the leadership void. ${ }^{233}$

In addition to the creation of the Department of Corrections, several new reforms in the operations of the ACI were put forth in an attempt to resolve some of the growing issues within the system. The most important policy changes and plans were that women would be back into the prison system of Rhode Island (and would reside in the Training School for Girls, where there was now room for them), the cottages at the Boys Training School would be renovated, the transfer of minimum security to the women's reformatory building, the transfer of the Youth Correctional Center, moving the awaiting trial inmates from maximum to the medium-minimum security building, the establishment of a special program for first time offenders, the expansion of an in-service training program, and citizen participation in programs. ${ }^{234}$

Meanwhile, fourteen officers began taking a college level course in corrections brought to the ACI by Salve Regina College (now University). ${ }^{235}$ Francis Foley, deputy warden of the medium-minimum security unit at the ACI, hailed this as the beginning of a "new era” for correctional officers in Rhode Island. ${ }^{236}$ Foley explained that more officers would take part in the program if they were offered the pay incentives similar to police officers. ${ }^{237}$ These officers completed the course on August

\footnotetext{
232 "Travisano Agrees With Philosophy of Report," The Providence Evening Bulletin, July 5, 1972, 60.

233 "Leadership at ACI," The Providence Evening Bulletin, July 7, 1972, 22.

${ }^{234}$ Paul Kelly, "Changes at ACI," The Providence Evening Bulletin, July 26, 1972, 1.

235 "14 ACI Guards Taking Course in Corrections," The Providence Journal, July 12, 1972, 13.

${ }^{236}$ Ibid.

${ }^{237}$ Ibid.
} 
12, and the course was so successful that the course would be expanded. ${ }^{238}$ This helped to increase professionalism within the workplace and also helped officers to be equipped to handle all of the demands that a "correctional officer" must deal with, in addition to security.

September of 1972 brought a manhunt for four escapees, three of which were convicted killers. $^{239}$ The inmates broke out through the chapel and slid down the downspouts on the side of the building to get to get away cars that were awaiting them. ${ }^{240}$ At the time, the general public could just drive right up to the building and this was an instance of a great lapse in the security of the building. ${ }^{241}$ This sparked an all-out manhunt to capture the prisoners and helped to foster fears within the community of Cranston in particular. Sadly, officials had been warned of the escape in advance by a select group of inmates and the state police had a stake-out outside the prison. ${ }^{242}$ They were still unable to thwart the plot.

A majority of the problem regarding the escape was that the officers were not warned that a plot was in the works. ${ }^{243}$ There was no system in place to brief a new shift coming in to work, and the administration saw no need to warn the officers in any case. John Galligan made an effort to correct earlier statements by prison personnel that insinuated that they had been kept in the loop. The entire incident also served to make a mockery of the entire system and bring further despair to those who were

\footnotetext{
238 “14 Complete Corrections Course,” The Providence Journal, August 12, 1972, 11.

239 “Officials Believe 4 Escapees Armed,” The Providence Journal, September 21, 1972, 1. “3 Killers Hunted in Break at ACI,” The Providence Journal, September 21, 1972, 1.

${ }^{240}$ Ken Rivard, Interview with the author, March 29, 2011.

${ }^{241}$ Ibid.

${ }^{242}$ David Donnelly, “ACI Alerted, but 4 Flee,” The Providence Evening Bulletin, September 21, 1972, 1.

${ }^{243}$ David Donnelly, “Guards: Not Alerted on Flight Plot,” The Providence Evening Bulletin, September 22, 1972, 1.
} 
making an honest effort for change, and those who were working within the system. ${ }^{244}$ A report that was published by a special investigating committee blasted both the state police officials and administrators within the ACI who were in charge, calling their path of action "astonishingly lax and unprofessional". ${ }^{245}$ ACI officers outside of the prison on normal patrol, who were not notified of the plot, noticed some oddities but failed to report them due to their lack of knowledge. ${ }^{246}$ The committee noted the lack of portable communications equipment, metal detecting equipment, written reports regarding unusual activity, secure parking, proper lighting, prison uniforms, regular visits by the warden or the deputies within the maximum security section, and a mandatory training program which would include training regarding "preparation of reports, prisoner control, riot training, small arms proficiency, and self-defense.”247 The report also demonstrates that the administration put the life of one of the officers at risk by not informing him of the situation at hand. ${ }^{248}$ This was not unusual. ${ }^{249}$ In responding to this report, Deputy Warden Roland Remillard explained that he was given ninety nine officer positions and yet he really needed one hundred and forty four to maintain security. ${ }^{250}$ While the training program was instituted fully in the next year, the rest of the recommendations regarding the physical conditions of the facilities would take another decade to be followed, due to lack of funds.

\footnotetext{
${ }^{244}$ A cartoon within the editorial section of the Providence Journal depicts a figure (either a prison or state police official) with his foot caught in his own trap that he laid for the escapees.

"Embarrassed," The Providence Journal, September 24, 1972, 62.

Also depicting the mockery is an editorial:

"Bungling at ACI," The Providence Journal, September 24, 1972, 62.

${ }^{245}$ Joel Sekeres, "Report Hits Warden, State Police Officer," The Providence Journal, November 3, $1972,1$.

${ }^{246}$ Ibid.

247 "Proposals Made by Probe Group,” The Providence Journal, November 3, 1972, 7.

${ }^{248}$ David Donnelly, “ACI Endangered Guard,” The Providence Evening Bulletin, November 6, 1972, 1.

${ }^{249}$ Ronald Brodeur, Interview with the author, March 17, 2011.

250 “More Guards Seen ACI Need,” The Providence Evening Bulletin, November 4, 1972, 23.
} 
It was under this state of increased scrutiny and increasing frustration that RIBCO entered into contract negotiations. This was extremely significant as the officers "had no contract for several years" and came forth with a set of demands. ${ }^{251}$ In a demonstration of solidarity, one hundred workers reported to a meeting in protest of the long delays in their contract negotiation process. ${ }^{252}$ Eugene Fagnant, grievance chair at that time, explained that the union was looking for pay increases to make their salaries equal to that of officers in Massachusetts and Connecticut. ${ }^{253}$ They were also looking for "seniority provisions" and "other benefits" ${ }^{254}$ Officers were being paid $\$ 8,500$ and were looking to increase their pay scale to $\$ 12,000{ }^{255}$ An increase in pay and benefits would help to attract better workers.

On November 19, the night shift called out sick in response to a lack of a contract. ${ }^{256}$ State troopers had to be called in to fill some of the positions. ${ }^{257}$ Civilian employees in the shops also stayed out of work in a show of support. RIBCO attorney Gerard Cobleigh met with Joeseph Murray (of the state personnel division) to iron out details involving full pay for officers who had been attacked on the job, state payment of funeral expenses, and paying double overtime on holiday Mondays (as consistent with the "long weekend" law) ${ }^{258}$ The officers returned to work with the reopening of salary negotiations by the governor. ${ }^{259}$ They received an agreement on their pay increase on November 29, a mere week after entering into negotiations regarding the

\footnotetext{
251 “ACI Guards Hold A Protest Meeting,” The Providence Evening Bulletin, October 18, 1972, 2.

${ }^{252}$ Ibid.

${ }^{253}$ Ibid.

${ }^{254}$ Ibid.

255 “ACI Officers, Licht Discuss New Contract,” The Providence Journal, October 27, 1972, 8.

256 "Guard Shift at ACI Out 'Sick'," The Providence Journal, November 20, 1972, 1.

257 “Troopers on Duty in ACI Sickout,” The Providence Evening Bulletin, November 20, 1972, 1.

${ }^{258}$ Ibid.

259 “Guards Back, Licht Slates Talks Today,” The Providence Journal, November 21, 1972, 1.
} 
wage increases. ${ }^{260}$ After this, the sick out was viewed to be one of the strongest weapons that RIBCO had within its arsenal. While they did not use it frequently, as to not be charged with irresponsibility, it was used in a manner which was effective and ended labor negotiations fairly quickly and favorably for the union.

Sickouts were typically used as tactics at the time because full-out strikes were forbidden by state employees. ${ }^{261}$ An officer at the time, Ronald Brodeur (who would become RIBCO president in the later part of the decade), explained that the Brotherhood was needed to ensure equitable pay for their officers. ${ }^{262}$ Officer safety and equitable wages were two points that the union always fought on and often would engage in job action for. This was not one battle, but a "long, hard fight", which was just beginning in the early 1970's. ${ }^{263}$ Ken Rivard, also an officer at the time, concurs with this and states that: "We had to bond together."264 They became very "vocal and strong" out of necessity, they needed to fill the "void" in leadership that existed and protect their fellow officers. ${ }^{265}$

The need for protection was clear, as the situation at the prison had only become more tumultuous. On November 26, in the midst of contract negotiations, Officer Robert Picard was taken hostage. ${ }^{266}$ John Galligan stated that this situation demonstrated the need for more officers. ${ }^{267}$ Cranston Mayor James Taft, responding to this situation and the earlier breakout of four convicts, disturbed by the possible

\footnotetext{
260 “ACI Guards Get Pay Increase,” The Providence Journal, November 30,1972, 1.

"Licht Signs Pact Giving Pay Hikes to Guards at ACI,” The Providence Journal, December 7, $1972,8$. ${ }^{261}$ Ibid.

262 Ronald Brodeur, Interview with the author, March 17, 2011.

263 Ibid.

${ }^{264}$ Ken Rivard, Interview with the author, March 29, 2011.

265 Ibid.

${ }^{266}$ Paul Giacobbe and Dante Ionata, “Armed ACI Inmates Seize Guard; Officials Argue on 'No repraisals',” The Providence Journal, November 26, 1972, A1.

${ }^{267}$ Ibid.
} 
danger this brought to his town, stated: "I'm tired of the studies and no action." "I think we should act now before a tragedy occurs in the city of Cranston., ${ }^{268}$ As more disruptions were predicted, it appeared that all of the public officials were concerned about the turmoil spilling out into the surrounding communities. ${ }^{269}$ While this was a valid concern to have, not one official appeared to be concerned for the safety and well-being of the workers within the prison. Officers were held responsible for the chaos as many used them as scapegoats, claiming that they were just not working hard enough to regain control. While this event may have worked to support the officers in their requests for a pay increase, the officers appeared to be viewed as a nuisance to the general public. Other state unions began demanding pay increases proportional to that of the officers and Governor Licht was put into the position of having to defend his support for increasing the pay of the officers. ${ }^{270}$

The year did end on a high note for the officers with their new contract and with the establishment of a required six-week training course. ${ }^{271}$ This course was meant to "instruct the men in their dual roles as security guards and rehabilitative officers". ${ }^{272}$ This would serve to clear up some of the confusion that had been voice by the officers with regard to policy directives. However, it would have been more constructive to institute this course before a separate panel issued a very public report,

\footnotetext{
${ }^{268}$ Dante Ionata, “Licht Statement on ACI: Won't 'Second-Guess', 'The Providence Journal, November 28, 1972, 1.

269 “Warden Predicts ACI Disruptions,”The Providence Evening Bulletin, November 28, 1972, 1. Another breakout was thwarted by an officer. “Guard Averts ACI Breakout,” The Providence Evening Bulletin, December 20, 1972, 1. Also, an inmate escaped, three prisoners fled work detail, and an officer was assaulted. “Inmate Escapes from State Prison,” The Providence Journal, December 28, 1972, 10. “2 ACI Prisoners Flee Work Detail, $3{ }^{\text {rd }}$ Recaptured,” The Providence Journal, December 29, 1972, 4. "Inmate Strikes ACI Guard,” The Providence Journal Bulletin, December 30, 1972, 6, 270 "Licht Defends ACI Pact," The Providence Journal, December 2, 1972, 10.

271 “Course Set for ACI Guards,” The Providence Evening Bulletin, December 21, 1972, 36. ${ }^{272}$ Ibid.
} 
condemning them for not already doing so. If they had listened to the officers grievances initially, perhaps a good deal of disturbances and public embarrassment could have been avoided. Overall, 1972 was instrumental in refining union tactics as well as making some hard won gains. The officers now had a new and improved contract, greater educational and training opportunities, legislation which made their jobs and lives a little better, and also had begun to flex their muscle within the realm of state politics. However, one thing of great concern to the officers still largely remained: constant threats to their safety and well-being.

\section{3: A Year of Violence}

Violence was the defining characteristic of 1973. Throughout the year, the ACI experienced several disturbances. Officers instituted lockups, on their own initiative (and without administrative support), in an attempt to maintain some semblance of order. One disturbance turned into a full-scale riot, in April, which damaged the infrastructure of the maximum security building and severely hampered operations. Most importantly for the Brotherhood was the killing of Officer Donald Price in June. This was a critical turning point for the officers as they realized the severity of their situation and banded together to ensure that this could never happen again.

The union worked throughout the year to gain allies within the administration and to protect those superior officers who supported the interests of the officers. Women also became crucial players (both as prisoners and workers), and began to take a greater role in shaping the direction of the reform process. The union also made great overtures to make the public aware of the precarious situation they were placed 
in during the reform process. As violence escalated, it became clearer that the reforms that were instituted were not done so properly and the prison system was in constant danger of descending into complete chaos.

The union had very few allies, particularly within the prison system itself. Inmates typically sought the transfer or reassignment of superior officers who attempted to instill order and supported the common officers. The inmates would inevitably clash with the officers over staffing policies and one such case involved the reassignment of superior officer Roland Remilliard. A brief sickout was staged by the union in response to the reassignment. ${ }^{273}$ The union believed the administration was engaging in "poor personnel practices” and believed that, in many cases promotion had been based on "patronage" rather than merit. ${ }^{274}$ This shows that the union was now beginning to take on the internal politics of the prison. This incident was indicative of the growing struggle for control between officers and the inmates.

The power balance between the inmates and the officers also began to change in the public sphere. In a blatant turning of the tide, prisoners held their annual legislative forum and yet, only one senator attended. ${ }^{275}$ Perhaps this was due to the officers making a case in the public forum, or due to the fact that the prisoners had dug their own grave with the public in instigating disturbances and inciting violence. Either way, this depicts a clear shift in the power structure from just a couple of years previously. Inmate organizations were clearly losing their influence over legislators.

\footnotetext{
273 Ibid.

274 “Guards Hold ‘Sickout', Relent,” The Providence Journal, January 17, 1973, 1. Interestingly, the Fraternal Order of Police, Lodge 24 also protested in a sympathy sickout. ${ }^{275}$ Duane Steele, “One Senator Attends ACI Legislation Forum,” The Providence Journal, February 20, 1972, 27.
} 
Changes in political offices and the administration had many implications for the ACI. Warden Howard would officially resign on April $18^{\text {th }} .{ }^{276}$ This post would be filled by James Mullen. The newly elected governor, Philip Noel, promised change for the prison system of Rhode Island. He stated that he believed the warden had moved too fast in instituting reforms and stated: “'I don't think you can move into some of these reforms unless you have the full confidence' of the deputy wardens, prison guards, and other prison administrators. ${ }^{277}$ Governor Noel appeared to be supportive of the correctional officers in discussing the philosophies of the warden. He stated that he believes the officers and the warden had a "basic conflict" in that the warden believes prisons are solely for rehabilitation where the officers understand it is for rehabilitation and punishment. ${ }^{278}$ He also stated: "You have to select a pace of change that makes sense, and you have to work with your corrections officers so that they'll understand and accept the kind of change you're going to implement...,279 The governor clearly understood the fundamental gap between the administration and its workers. He also brought attention to the fact that the administration had not been working in sync with its workers, which led to confusion.

President Galligan fought vehemently throughout 1973 to make the public aware of the precarious situation the officers found themselves in when balancing the need for reform with safety. He argued that there was an "in-between” between reform and security and pushed for what he termed as "the establishment of some

\footnotetext{
276 "Warden of ACI Resigns,” The Providence Evening Bulletin, April 18, 1973, 1.

277 "Noel Will Decide Changes at ACI," The Providence Evening Bulletin, April 5, 1973, 1.

${ }^{278}$ Ibid.

${ }^{279}$ Ibid.
} 
definite policies and procedures to be followed by the prison personnel."280 Anthony Travisano, director of the Department of Corrections, implied that the officers had been a roadblock in the way of implementing reforms. ${ }^{281}$ President Galligan, in an exasperated and angry response, explained to the Providence Journal reporters that a major failing of Travisano’s administration had been “a lack of clearly defined policies for the guards”. ${ }^{282}$ They felt the administrative officials consistently made decisions with an apparent lack of regard for security considerations. One example given was the decision to let numerous visitors into the prison at night, where they were short-shifted. This "severely taxed” an already over-worked group of officers and created some security concerns. ${ }^{283}$ Galligan further retorted that this was part of their negotiations in the previous year and that they were still waiting for the distribution of these procedural rules. ${ }^{284}$ He reiterated that the officers were not against reform, yet needed to have some safeguards in that they needed more staff to implement the programs safely. ${ }^{285}$ Retired Captain Ronald Brodeur, in recalling situations like these, stated: “If it weren’t for the union, management would make decisions that would definitely jeopardize the safety of the staff that work here”. ${ }^{286}$ Officers had to band together to keep from being consistently placed in compromising situations.

\footnotetext{
${ }^{280}$ David Donnelly, “Travisano Answered by Guards,” The Providence Evening Bulletin, April 6, 1973, 1.

${ }^{281}$ Robert Baldwin, "Reform at ACI Still Favored by Travisano,” The Providence Journal, April 6, 1973, 1.

${ }^{282}$ David Donnelly, “Travisano Answered by Guards,” The Providence Evening Bulletin, April 6, 1973, 1.

${ }^{283}$ Ibid.

284 Ibid.

285 Ibid.

${ }^{286}$ Ronald Brodeur, interview with the author, March 17, 2011.
} 
The ACI underwent a fairly extensive grand jury probe regarding the four escapees of the previous year. In this probe, various suggestions were made for security. ${ }^{287}$ Mr. Travisano acknowledged that a good deal of clerical work and physical labor was being done by officers, when the tasks could be performed by civilian workers. ${ }^{288}$ In adding staff that could alleviate the duties of the officers, Travisano was hoping to cut down on the amount of money being spent on overtime. $^{289}$

Also, the women's facility was growing and developing and gaining greater attention in the local media. ${ }^{290}$ This meant that there would be greater opportunities for females looking to work in the field of corrections. At this time, only male officers were allowed to work in male prisons. The facility, reestablished the previous year, housed twenty one inmates. Deputy Warden Gloria McDonald attributed the growing population of sentenced women to the fact that there was actually a facility within the state to hold them, as previously judges did not want to send these women away from their families. She also came out in favor of the new "trend" in reform policies and explained that, in the women's facility, they were able to try things with the prisoners that they were not able to in a larger facility. ${ }^{291}$

Despite the growing discourse regarding security and new ideas for reform, violence ran rampant as the struggle for control between the inmates and officers intensified. On April 2, 1973, the ACI underwent a riot in which four guards were

\footnotetext{
287 "16 Inmates, ACI Guard Indicted in Escape of 4,” The Providence Evening Bulletin, February 27, $1973,1$.

${ }^{288}$ Robert Baldwin “More Hiring Eyed to Cut Overtime,” The Providence Journal, March 8, 1973, 2.

${ }^{289}$ Ibid.

290 “R.I. Prison Official Says Reforms Not Lax,” The Providence Evening Bulletin, March 26, 1973, 20.

${ }^{291}$ Ibid.
} 
injured and many fires were set. ${ }^{292}$ In the earliest hours it was rumored that inmates were holding hostages and battling "hand-to-hand” with officers and police. ${ }^{293}$ Officers characterized it is a full-scale riot and announced that the inmates had "taken over the place". ${ }^{294}$ All of the industrial shops were destroyed. ${ }^{295}$ Violence had been escalating over a ten day period including five stabbings and a fight between two groups of African American inmates. ${ }^{296}$ The surrounding community was upset by the disturbance and Mayor Taft was extremely agitated with his lack of information, particularly since his town's emergency vehicles were responding to the situation. Later reports explain that two hundred inmates were involved in the riot and it went on for about three hours. ${ }^{297}$ Aides to the governor forecasted the damage would cost millions of dollars. ${ }^{298}$ It was confirmed that officers were held hostage, yet were luckily let go. ${ }^{299}$ It appeared to the officials that it was a spontaneous riot. ${ }^{300}$ A segment in the Providence Journal, titled "Day the ACI 'Exploded,"” featured a series of pictures of the riot, the prisoners (all looking fierce and wild), a weary Warden Howard, and the damage. ${ }^{301}$ Inmates blamed Roland Remilliard, deputy warden, for the escalation of tension, as they were clearly unhappy with his attempts to regain control of the facility. ${ }^{302}$ However, the level of violence that resulted shows just how

\footnotetext{
292 “4 Guards Hurt, Fires Set in ACI Melee,” The Providence Evening Bulletin, April 2, 1973, 1.

${ }^{293}$ Ibid.

${ }^{294}$ Ibid.

${ }^{295}$ Ibid.

${ }^{296}$ Ibid.

${ }^{297}$ Edward Wood, “Rampage Leaves ACI in Shambles,” The Providence Journal, April 3, 1973, 1.

${ }^{298}$ Ibid.

${ }^{299}$ Ibid.

${ }^{300}$ Ibid.

${ }^{301}$ George Rooney and Jack Spratt, “Day the ACI ‘Exploded,”’ The Providence Journal, April 3, 1973, 7.

302 "Inmates Cite Buildup of Tension and Blame ACI Deputy Warden,” The Providence Journal, April 3, 1973, 6.
} 
extreme the situation was becoming and how united and firm the officers remained in the wake of violence.

The women's facility which was also enduring a good deal of turmoil, experienced a separate disturbance of their own on April $6{ }^{\text {th }} \cdot{ }^{303}$ Female inmates were displeased when a woman, who refused to return to her cell, was brought back to her cell by means of physical force. The other women refused to return to their cells at first, but eventually complied with requests. The women believed that the programs at the ACI were inferior when compared to other facilities (such as Framingham, where they were all previously held). ${ }^{304}$ One of the causes of this particular incident was that it was two male officers who brought the female to her cell. While the women's facility did employ some female officers, males worked there as well. This did not work the other way around for years to come. This unrest would serve to increase the similarities between female and male officers within the union.

The maximum security complex was severely damaged by fire during the rioting and was already overcrowded. ${ }^{305}$ The administration and officers now faced the problem regarding the destruction of the industrial buildings. While there were not any rehabilitation programs to speak of, there were jobs that occupied many of the inmates' time. Now, with the destruction of the shops, inmates would be idle and more likely to engage in more rebellion. Officers were also subjected to a good degree of verbal abuse and were the targets for many who were throwing objects from

\footnotetext{
303 “Women," The Providence Evening Bulletin, April 6, 1973, 1. “Women’s Prison Has Disturbance,” The Providence Journal, April 7, 1973, 10. ${ }^{304}$ Ibid.

${ }^{305}$ David Donnelly, “Overcrowding Strains ACI Top-Security Unit,” The Providence Evening Bulletin, April 10, 1973, 1.
} 
their cells during the lockup that followed the riot. ${ }^{306}$ Yet the officers remained in fairly good spirits despite the overtime work in cleaning up the prison and the abuse. $^{307}$ It appeared as though the public may finally take the issues that they were facing seriously and provide them with the resources they needed.

However, the Rhode Island House Finance Committee apparently did not take the monetary needs of the prison as seriously as other segments of Rhode Island were beginning to. They voted to cut $\$ 100,000$ from the funding available to hire more officers for the squad who handled prisoners in transit. ${ }^{308}$ Attorney General Israel stated that he felt there was a “'deep-seated' tendency 'not to spend more on the criminal justice system.’”309

In the midst of all of this, Captain James W. Mullen was appointed to be the new warden. ${ }^{310}$ He promised the staff “strong support” but also demanded that everyone recognize that he was in charge. ${ }^{311}$ He had a good deal of experience within the Rhode Island state police force. He also stated that he was concerned with the "performance of the correctional officers" and elaborated that they had been without leadership for the previous three or four months. ${ }^{312}$ He explained that the channels of communication were open with the Brotherhood. ${ }^{313}$ He also specified that he was first concerned with security and discipline” and that "everything else follows that.”314 Editorialists, while looking upon the warden’s tough approach favorably, were

\footnotetext{
${ }^{306}$ Ibid.

${ }^{307}$ Ibid.

308 "Prison Guard Fund Cut Questioned," The Providence Journal, April 27, 1973, 14.

${ }^{309}$ Ibid.

${ }^{310}$ Paul Kelly, “Capt. Mullen Appointed ACI Warden,” The Providence Evening Bulletin, May 7, 1973, 1.

${ }^{311}$ Ibid.

312 Ibid.

313 Ibid.

${ }^{314}$ Ibid.
} 
concerned that he was working too hard to appease the public, and was not properly emphasizing the need for funding for change. ${ }^{315}$

Within his first ten days, the warden issued several directives regarding policy both for the inmates and for the officers, much to the satisfaction of the union. ${ }^{316}$ He also directed the officers to maintain a “'spit and polish’ image” and to refer to inmates as with proper titles (i.e. “Mr.”). ${ }^{317}$ In response, inmates were expected to show the same respect by referring to the correctional officers as "officer". ${ }^{118}$ If inmates were to strike an officer, they would receive thirty days in segregation and restricted visitation. $^{319}$ These directives also served to reestablish a chain of command. He also maintained that he would be the "official spokesperson" for the prison, in an effort to cut down the very public nature of the feuds within the prison environment. $^{320}$ It is clear that Warden Mullen valued the safety of his workers and it was a foremost concern for his administration. Also, by attempting to cut down the statements to the press, this policy would also work to improve labor relations between the administrators/managers and the workers. This was a marked change from policy in the past.

The inmates of maximum were placed in lockup in May, by the request of the officers. $^{321}$ This was in response to threats and bad behavior. The union voted to reinstitute a lockup themselves “as long as necessary until the administration put

\footnotetext{
315 “A New Warden,” The Providence Evening Bulletin, May 14, 1973, 26.

316 "Sources at ACI Report New Warden Cracking Down,” The Providence Evening Bulletin, May 16, $1973,47$.

${ }^{317}$ Ibid.

${ }^{318}$ Ibid.

${ }^{319}$ Ibid.

${ }^{320}$ Ibid.

321 “ACI Guards Win on Lockup Issue,” The Providence Evening Bulletin, May 31, 1973, 1.
} 
together some type of program that brings about a degree of order”. ${ }^{322}$ Confrontations were escalating between officers and inmates. Two specific instances prompted direct action on the part of the union. The first involved an inmate threatening an officer with a baseball bat. The second involved inmates forcing the officer to open up a door to a section of the prison, using threats of force. They had begun to use their numbers to force officers into certain actions or keep officers from performing their duties. ${ }^{323}$ President Galligan stated: "It had become absolutely impossible for the officers to function.”324 Galligan cited problems with smuggled contraband in the form of weapons, drugs, and alcohol, in addition to the inmates’ ability to essentially roam about freely and idly. ${ }^{325}$ The union believed that privileges should be gained based on good behavior. ${ }^{326}$

Instituting a lockup (on their own initiative) was an action that had no precedence. While the writers of the Providence Journal did not appear to support the demands of the officers, it was clear that the union had taken the stance that it would act on behalf of its members' safety in the workplace. ${ }^{327}$ The newspaper described the officers as being more "militant" in their labor actions in the past few years. ${ }^{328}$ The union was described as generally “seeking a voice in prison operations”. 329

This was the equivalent of a union "sit-in". "Sit-ins" are used by labor organizations for various reasons. The first reason is that the workers could not be

\footnotetext{
322 Ibid.

323 Ibid.

324 “Management Say for Guards,” The Providence Evening Bulletin, June 1, 1973, 1.

325 Ibid.

${ }^{326}$ Ibid.

327 “ACI Guards Win on Lockup Issue,” The Providence Evening Bulletin, May 31, 1973, 1.

"Management Say for Guards," The Providence Evening Bulletin, June 1, 1973, 1.

${ }^{328}$ Ibid.

${ }^{329}$ Ibid.
} 
merely replaced with more workers, in this case, the state police. It severely disrupts the mode of "production". The technique became popular in 1936 and 1937 and was wildly effective, and was first widely publicized with the strike of the United Auto Workers in Flint Michigan, the Works Progress Administration artists’ strike at the WPA headquarters, and the strike at Firestone Tire Plant No. 1 in Akron, Ohio. ${ }^{330}$ This kind of a strike protected workers from the elements and from police forces looking to engage them. ${ }^{331}$ The workers could use their workplace (usually a factory) as a kind of fort. ${ }^{332}$ Management was much more willing to negotiate to get "production” going again and to maintain their resources within the building. Galligan justified the action by saying: “We’re not going to walk out on a situation. We’ve got a job to do and we're going to do it right.”333 However, as a labor tactic, this was one that elicited an immediate response.

The very next day, Governor Noel announced some major changes that would be instituted to "improve security," which would in turn make the working conditions of the officers easier. ${ }^{334}$ The plan would hire additional correctional officers, eliminate overtime, install a new guard tower, and move awaiting trial prisoners from maximum security to medium security. Also, the governor announced the beginning of a \$195,000 federally funded inmate training program, created a “Director of Education” job, and also established a psychological treatment program.

\footnotetext{
${ }^{330}$ Richard Boyer and Herbert Morais, Labor's Untold Story, United Electrical, Radio \& Machine Workers of America, Cameron Associates, New York, N.Y., 1955, 293.

${ }^{331}$ Ibid.

332 Ibid.

333 Ibid.

334 “Noel Sets Tighter Security at ACI,” The Providence Evening Bulletin, June 1, 1973, 1.
} 
June of 1973 proved that things would become more difficult for the officers before they got any easier. Officers were constantly under siege as the violence escalated further. While inmates in maximum were under lockup, inmates in the medium security facility became more psychically aggressive with the officers. On June $1^{\text {st }}$, one officer was assaulted an injured and another locked in a cell after being threatened at knifepoint. ${ }^{335}$ On June $3^{\text {rd }}$, three officers (Donald Price, James Nagy, and Reginald Wilcox) were seized and held at knifepoint for a half an hour while inmates negotiated conditions in the prison. ${ }^{336}$ Two more officers (Lt. Edward McKenna and Leo Duffy) were held hostage for a half an hour on June $10^{\text {th }} .{ }^{337}$ At this point, Governor Noel realized that some action needed to be taken. He angrily ordered officials at the ACI use "whatever means are necessary" to control the prison. ${ }^{338} \mathrm{He}$ also made sure to infer that the court decisions of Judge Pettine had constrained both Warden Howard and the present administration, but his order was meant to provide for the safety of the staff and surrounding community even if it came into direct conflict with the decisions of Judge Pettine. ${ }^{339}$ In other words, if the orders of Judge Pettine were putting lives at risk, they were to be disregarded. ${ }^{340}$ He ended statements in saying: "'We're going to protect those prison guards and we'll take whatever measures we have to do that. ${ }^{341}$

\footnotetext{
335 “Trouble Continues Despite the Lockup,” The Providence Evening Bulletin, June 1, 1973, 10.

${ }^{336}$ Franklin Prosnitz, "3 Guards Seized By Inmates in New Disturbance at ACI," The Providence Journal, June 3, 1973, 1.

${ }^{337}$ Franklin Prosnitz, "2 ACI Guards Held Hostage for Half-Hour," The Providence Journal, June 11, 1973, 1.

${ }^{338}$ Charles Bakst, “Noel: Use Any Means To Control Prison,” The Providence Journal, June 12, 1973, 1.

339 Ibid.

${ }^{340}$ David Donnelly, “Hard Line Policy for ACI,” The Providence Evening Bulletin, June 12, 1973, 1.

${ }^{341}$ Ibid.
} 
Yet, all of this was to no avail. On June 22, 1973, Officer Donald Price was stabbed to death in the medium security section, at the age of $24 .{ }^{342}$ Officer Price was new on the job, only having been there a few weeks. ${ }^{343}$ Lt. Ken Rivard refers to this as a pivotal moment for the ACI and for the union. ${ }^{344}$ After this, officials and the public began to take the daily problems and conditions facing the officers much more seriously. ${ }^{345}$ Retired Captain Ronald Brodeur was hired just after the death of Officer Price. He says that Rhode Island has been "lucky" since the death of Officer Price in 1973, as they have not had to experience this again. He attributes this to the "efforts of the Brotherhood" who "fought tooth and nail" to protect its officers. ${ }^{346}$ It is clear that each officer knew that it could have been them who was murdered. Those who knew Officer Price felt the loss and anger toward this tragedy and were certain to make sure that this did not happen again.

This murder brought about, what the Providence Journal would term, a "backlash” ${ }^{347}$ Governor Noel asked for the General Assembly to pass legislation making the murder of a correctional officer or any person within the prison punishable by the death penalty. ${ }^{348}$ Officers were defined as being "angry, bitter, and most of all, united”. ${ }^{349}$ One officer explained: "I just don’t see how any officer could go back in with the feeling that nothing has happened.”350 Many questioned why Officer Price was targeted, and most just seemed to believe that it was just because he was an

\footnotetext{
342 “Guard Stabbed to Death at ACI,” The Providence Journal, June 22, 1973, 1.

343 Ibid.

${ }^{344}$ Kenneth Rivard, Interview with the author, March 29, 2011.

345 Ibid.

${ }^{346}$ Ronald Brodeur, Interview with the author, March 17, 2011.

347 “Killing Stirs Backlash,” The Providence Journal, June 23, 1973, 1.

${ }^{348}$ Ibid.

${ }^{349}$ James Rosenthal and Don Abood, “Stunned ACI Guards angry, bitter, and determined,” The Providence Evening Bulletin, June 23, 1973, 8.

${ }^{350}$ Ibid.
} 
officer, nothing more. ${ }^{351}$ John Galligan made it clear that every officer who was offduty would be at the officer's funeral on the following Monday, in uniform. ${ }^{352}$

Unfortunately, at the same time, training for officers was cut from six weeks down to two, in an attempt to bolster the forces at the prison. ${ }^{353}$ The legislature was now moved to act to hire twenty-five more officers. ${ }^{354}$ Legislation that mandated death by hanging for anyone who committed a murder "while committed to confinement” at the ACI made its way through the General Assembly. ${ }^{355}$ This was changed to death by the gas chamber and was passed on June $26^{\text {th }}$ (four days after the murder). ${ }^{356}$ Guards showed up in support of the legislation, and were shown in the paper looking solemn in uniform in the Senate chambers. ${ }^{357}$

Governor Noel then, in a rather startling move, approved a plan to hire seventy seven more officers and five more kitchen and hospital workers. ${ }^{358}$ This fell in line with his original plan to cut overtime, although it is likely that the number of officers hired may have increased since the death of Officer Price. As for the financing, Noel said that he would defer the cost by proposing a deficiency appropriation bill in the 1974 legislative session. ${ }^{359}$

\footnotetext{
${ }^{351}$ Ibid.

${ }^{352}$ Ibid.

353 "Guards training period cut from six weeks to two," The Providence Journal, June 23, 1973, 8.

354 "Garabedian Intends to File Bill for 25 More ACI Guards," The Providence Journal, June 25, 1973, 25.

${ }^{355}$ John Hacket, “Death Penalty Bill Prepared for Assembly,” The Providence Journal, June 26, 1973, 1.

356 “Assembly Oks Death Bill, Revamped Regents Board,” The Providence Journal, June 27, 1973, 1. ${ }^{357}$ Ibid.

358 Joel Sekers, “Noel Approves Plan to Hire 77 ACI Guards,” The Providence Journal, June 27, 1973, 19.

${ }^{359}$ Ibid.
} 
Meanwhile, pandemonium continued at the ACI when an escape tunnel, dug by ten inmates, was found. ${ }^{360}$ This tunnel had been suspected for months but now a more vigorous search was conducted by the state police since the murder a week earlier. $^{361}$ Thirty inmates who were consistently inciting trouble and violence were placed in a "special cellblock," to keep them from interacting with the other prisoners. ${ }^{362}$ Director of corrections, Anthony Travisano, was quoted as saying: "Some of them may never see the light of day again, and you can quote me on that."363 It was his intention to make sure that the entire prison population did not pay for the sins of the others. ${ }^{364}$

In response to this violence, administrators and politicians both took immediate action to remedy some of the most pressing security concerns the officers brought forth. Management attempted to gain improve the communications systems fairly quickly by making attempts to obtain radio communications devices for the officers. ${ }^{365}$ They required federal funding and, unfortunately, bureaucracy hindered the progress of obtaining these devices. This was not just for riots, but also for every day usage. ${ }^{366}$ $\$ 90,000$ of federal funds were approved for a new communications system at the ACI in October. ${ }^{367}$ It was also clear that state troopers would be needed at posts for a few

\footnotetext{
${ }^{360}$ David Donnelly, “Escape Tunnel Dug by 10 is Found,” The Providence Evening Bulletin, June 29, 1973, 1.

${ }^{361}$ Ibid.

362 “Chronic ACI Troublemakers Placed in Special Cellblock,” The Providence Journal, July 1, 1973, B7.

363 Ibid.

364 Ibid.

${ }^{365}$ John Hackett, “U.S. Stalls ACI Radio Updating,” The Providence Evening Bulletin, July 9, $1973,1$.

${ }^{366}$ Ibid.

${ }^{367}$ Doane Hulick, “R.I. Crime bd. Okays \$90,000 for ACI,” The Providence Journal, October 5, 1973, 3.
} 
more months. ${ }^{368}$ Governor Noel also established a special force within the state police department to be ready to handle disturbances at the ACI at a moment's notice. ${ }^{369}$ The administration discovered that it was difficult to find new employees to fill the forty six vacant positions, as new officers kept quitting. ${ }^{370}$ The warden also began to back the privatization of various shops within the ACI (instead of being owned by the state). ${ }^{371}$ The year ended with the claim that the ACI had "gain[ed] new security" in that there were numerous physical improvements being made to the facilities as well as a good working relationship between the officers and the warden. ${ }^{372}$ The most positive development of the year was that officer safety gained its rightful place in the public discourse and was now a matter of public concern. However, not everything was positive as December saw yet another inmate disturbance in which fifty inmates had a giant brawl in the dining area. ${ }^{373}$ It was clear there was still a great deal of work to do.

Also at the end of 1973, RIBCO held an election. The union elected a new president, Eugene Fagnant. ${ }^{374}$ Also elected in 1973 were: Robert Mertz for vice president, Robert Jenckes as second vice president, Robert Blanchard as secretary, Albert Gardner as financial secretary, and Joseph Montecalvo as recording

\footnotetext{
${ }^{368}$ Doane Hulick, “Troopers May Stay at ACI Posts for 3-4 More Months,” The Providence Journal, July 24, 1973, 38.

369 Paul Kelly, “Governor Noel: Special Force to Handle ACI Strife,” The Providence Evening Bulletin, September 5, 1973, 1.

${ }^{370}$ John Hackett, “New Guards Jobs at ACI Unfilled,” The Providence Journal, November 16, 1973, 27.

371 “ACI Warden Backs Jobs Inside Prison,” The Providence Journal, December 4, 1973, 11.

372 David Donnelly, “ACI Gains New Security,” The Providence Evening Bulletin, October 9, $1973,1$.

373 “50 Inmates in Brief Brawl in Dining Area,” The Providence Evening Journal, December 6, 1973, 1. 374 “Union Guards at ACI Elect a New President,” The Providence Evening Bulletin, October 16, 1973, 17.
} 
secretary. ${ }^{375}$ The union closed out 1973 with the rejection a two-year contract offer due to an insufficient salary being offered. ${ }^{376}$ The union also argued for improvements to the state retirement system, for financial protection against lawsuits against officers, and for the "liberalizing" of pay benefits offered to injured officers (including improved medical coverage). ${ }^{377}$ New RIBCO president, Gene Fagnant explained that the pay and benefits need to be better in order to attract and keep new officers. ${ }^{378}$ These were concerns that would continue throughout 1974.

\section{4: Protecting Officers At All Costs}

1974 was characterized by contract negotiations, work stoppages by officers in response to assaults, more discussions over prisoners' rights and prison reform, and more schemes for how to best reorganize the ACI so that it would function without disruption. Overall, this year showed a weakening of the administration's resolve to protect its workers and not give in to the demands of the inmates. Officers now had an established procedure put into place to protect their interests, yet they needed to make sure that it worked as it was intended to work. It was very clear throughout this year that the priority of the union was the safety of the officers above all else. For the first half of the year, RIBCO demonstrated its strength and militancy through threats of job actions or job actions themselves. In the second half of the year, RIBCO promised the governor that they would give up work stoppages, if their procedure was properly implemented and their officers were protected. This was a large concession for the union to make, particularly as the administration's resolve appeared to be breaking

\footnotetext{
${ }^{375}$ Ibid.

376 “ACI Guards Reject Pact; Call Pay Inadequate,” The Providence Evening Bulletin, December 28, 1973, 2.

${ }^{377}$ Ibid.

${ }^{378}$ Ibid.
} 
down. However, it was the only option for the union as it was the most responsible route for the safety of the prison and the governor had taken a stricter stance against work stoppages. The union, in an attempt to fix the problems with maximum security, requested a study which would investigate why medium security ran productively and securely while maximum was in such a state of chaos. Union officials hoped that an outside committee would find that tension between the administration and officers was to blame. Overall, the union demonstrated throughout the year that they were willing to work with management and state officials until their safety was disregarded.

The year began on a tumultuous note as fifty-five inmates refused to go back to their cells, demanding more recreation time. ${ }^{379}$ All of these inmates were awaiting trial, none of them were serving sentences. ${ }^{380}$ The state police responded quickly and the incident appeared to have been solved by the warden agreeing to make “adjustments" to recreation times on the following day. ${ }^{381}$ This set precedence for more inmate action, as the inmates found that this tactic would get them concessions from the administration.

New officers, just out of training, described the ACI as a "mess"382 The new officers blamed this mess partially on the rulings by Judge Pettine and partially on the unwillingness of officers because there was no one willing to start a "one-man crusade for uniformity of regulations of enforcement”. ${ }^{383}$ Officers, in response to this, defend their lack of action by explaining that their administrators do not support them when

\footnotetext{
379 “ACI Inmates Balk at Going to Cells,” The Providence Journal, January 2, 1974, 9.

${ }^{380}$ Ibid.

${ }^{381}$ Ibid.

${ }^{382}$ David Narsavage, “New Guards See Discipline 'Mess,'” The Providence Evening Bulletin, January 3, 1974, 1,

${ }^{383}$ Ibid.
} 
they do try to report on an inmate because it is "almost too involved to be worth the trouble” due to Pettine’s regulations. ${ }^{384}$ Travisano, head of corrections, expected to solve this by printing up a new book of regulations within that same week. ${ }^{385}$ This would not solve the fact that the administrators within the prison were unwilling to support the officers in confrontations. Inactivity and loitering were the two major problems that remained unsolved, according to a Providence Journal writer who toured with the new officers. ${ }^{386}$ As David Narsavage, Providence Journal writer put it: "What he’s spending six weeks to prepare himself for is to go behind bars, armed with only a whistle, grossly outnumbered by inmates, to work for about $\$ 3.70$ an hour.” What this article did not bring to light was that the officers had to be prepared to do this and not be supported by the administration when trying to follow their guidelines. This would be a source of major contention for the rest of the year.

Taking into consideration the lack of good relations between the workers and management, it was unsurprising that negotiations for the new contract for the upcoming year were not going well. The executive board threatened to refuse all overtime due to the fact that negotiations were dead-locked. ${ }^{387}$ This action was condemned as “irresponsible” by the governor, however it was effective in gaining them a meeting for the following day. ${ }^{388}$ The governor, in an effort to break the dead-

\footnotetext{
${ }^{384}$ Ibid.

385 Ibid.

${ }^{386}$ Ibid. In addition to this, the National Prison Reform Association (NPRA) set up a take-out food service. Robert Baldwin, “ACI Inmates Start 'Take-out' Food Service,” The Providence Journal, January 5, 1974, 7.

Many would view this, in the future, as a nuisance and a cause of disruption. William Laurie, Interview with the author, May 3, 2011

387 “ACI Guards Threaten to Refuse Overtime in Dispute Over Contract,” The Providence Evening Bulletin, January 7, 1974, 21.

${ }^{388}$ Ibid.
} 
lock in negotiations then offered to change the contract from two years to one year, giving the union an opportunity to renegotiate the following year. ${ }^{389}$ The one year contract would contain an increase of eleven percent. ${ }^{390}$ The governor essentially ignored all of the pension plan requests and requests regarding incentives for those with college training. ${ }^{391}$ The union ultimately rejected this plan and produced a counter-proposal in which they had a two-year contract with options for renegotiating after the first year was done. ${ }^{392}$ They still had qualms with the wages and the retirement plan put forth. ${ }^{393}$ Governor Noel was then, in a later article in the Providence Journal, quoted as saying that he was confident that the officers would not hold a slow-down in the prison. ${ }^{394}$ This then prompted an immediate slow-down of the officers, who clearly did not appreciate the statement. Fifty-three officers turned down an extra shift (stating they were ill), and state troopers as well as new recruits were assigned to their posts. ${ }^{395}$ Travisano stated that if necessary, he would "order" the men to work and produce evidence of illness, if necessary. ${ }^{396}$ Officers displayed their frustration in informing the press that they had been negotiating for three months, to no avail. ${ }^{397}$ The union offered up yet another contract proposal, which was then rejected by Governor Noel. ${ }^{398}$ Officers then accepted overtime shifts in an attempt to

\footnotetext{
389 John Kiffney, “ACI Offer Made By Noel,” The Providence Journal, January 15, 1974, A1.

${ }^{390}$ Ibid.

${ }^{391}$ Ibid.

${ }^{392}$ Wayne Worcester, “ACI Union Rejects Noel Plan,” The Providence Journal, January 16, 1974, A11.

${ }^{393}$ Ibid.

${ }^{394}$ John Hackett, “Noel Confident ACI Guards Won’t Hold Slowdown,” The Providence Evening Bulletin, January 17, 1974, 27.

395 Joel Sekeres, “53 Guards Veto Extra Shift,” The Providence Journal, January 22, 1974, A1.

${ }^{396}$ Ibid.

${ }^{397}$ Ibid.

398 “New Contract Proposal Offered By ACI Guards,” The Providence Journal, January 23, 1974, B3.

"Proposal rejected by Noel," The Providence Journal, January 24, 1974, B1.
} 
persuade the governor to reconsider. ${ }^{399}$ It seemed that attempts to strong arm Governor Noel into discussing matters with them would not be effective. After five months of negotiating and still no contract, RIBCO president Fagnant explained that his members could not accept the governor's rejection of their overtures at a compromise and that job action should be expected as a result. ${ }^{400}$ This prompted some response from the governor's office. They finally reached an agreement on February 13 which did not provide for a wage reopener at the end of the year, however they were given additional money at the end of the year to compensate. ${ }^{401}$ Both sides pushed as far as they could and total job action was not something that either side wanted to risk, as it would jeopardize any progress made in the prison.

In the meantime, there were many proposals as to what path of action would be best for the ACI to undertake for progress to occur. Some rumors of plans to relocate the ACI were circulating. ${ }^{402}$ Corrections director, Travisono, stated that there was a team of consultants from Illinois who were devising ten to fifteen different approaches for bringing change to the ACI. ${ }^{403}$ About ten days later, Travisono stated that institutions would remain in Cranston, even if they had to build a new facility, much to the dismay of Cranston mayor Taft. ${ }^{404}$ In the following months, Travisano was quite indecisive on the exact direction of the development of the ACI. All of these directions implied major policy changes and also implied a change in the working environments of all officers. Eventually the consultants recommended a plan that

\footnotetext{
${ }^{399}$ Terry Shwardron, “Guards Set to Accept Overtime,” The Providence Journal, January 25, 1974, A15.

400 "Guard Chief Hints at Action on Contract," The Providence Journal, February 8, 1974, B4.

401 "ACI Guards and State Reach Tentative Accord,” The Providence Evening Bulletin, February 13, 1974, C4.

402 Don Abood, “Early Decision Held Unlikely On ACI,” The Providence Journal, January 8, 1974, 25.

${ }^{403}$ Ibid.

${ }^{404}$ Terry Schardron, “ACI Seen Staying in Cranston,” The Providence Journal, January 18, 1974, B1.
} 
focused on community involvement, a focus on rehabilitation, and an expanded use of probation and called for the establishment of four community-oriented centers. ${ }^{405}$ The report also gave options for renovating or rebuilding the facilities yet argued that $\$ 7.5$ million that was authorized by voters would not be enough to cover this kind of a plan. ${ }^{406}$ While these plans were admirable in their idealistic nature, many questioned the feasible nature of such a plan. This would have meant extreme change in a very short period of time, something that had not proven to work well in the past. Retired Captain and former RIBCO President, Ron Brodeur explains the pattern of the Department of Corrections regarding consultants. Outside consultants were brought in and attempt to create plans and cut staff and, in the meantime, millions of dollars were wasted in trying to come up with these ideas, as they were not feasible. ${ }^{407}$ This was a pattern that continued through the 1970's and into the 1980's.

Corrections director Travisano also had a significant problem with the amount of overtime that was still occurring, despite the governor's ban on overtime in the previous year. ${ }^{408}$ This amount of overtime amounted to $\$ 800,000 .^{409}$ In response President Fagnant charged the "mismanagement” of the state Department of Corrections as being the reason for such a high amount of overtime, not officers who take "unneeded sick leave". ${ }^{410}$ This is a debate that will carry on through the decades despite numerous attempts to remedy the situation.

\footnotetext{
${ }^{405}$ Don Abood, “ACI Study Suggests Reforms,” The Providence Journal, May 8, 1974, A1.

${ }^{406}$ Ibid.

${ }^{407}$ Ronald Brodeur, Interview with the author, March 17, 2011.

${ }^{408}$ Hamilton Allen, “ACI Guard’s Overtime \$800,000 Despite Overtime Ban,” The Providence Evening Bulletin, June 4, 1974, A1.

${ }^{409}$ Ibid.

${ }^{410}$ Hamilton Allen, “ACI Guards Blame State on Overtime,” The Providence Journal, June 7, 1974, B2.
} 
The administration had also failed its officers by not adequately reinforcing established procedure that was in place to protect the officers. The administration did not view the safety of the officers as its major priority and this resulted in job action. On July 16, officers refused to report to work because an inmate who fought with an officer (Officer Louis Ward) was not dealt with in a manner consistent with the established procedure. ${ }^{411}$ Originally, the strike was not a union action, yet later in the day the union voted to support it. ${ }^{412}$ The decision not to place the inmate in segregation came from the fact that no other officer was around to witness the fight. ${ }^{413}$ President Fagnant stated: "The question is the safety of the employees. If they (superiors) don’t look out for our welfare, we will have to look out for our own." ${ }^{414}$ Some officers argued that Warden Mullen had broken his promise and also believed that some inmates got preferential treatment and that the officers were receiving less support from their administrators. ${ }^{415}$ The officers refused to go to work even though they had a contract, and thus Governor Noel fired them. ${ }^{416}$ Noel called Fagnant and said to him that they ought to settle the matter quickly or they would be "looking for other jobs" ${ }^{417}$ This was the first time Guardsmen had been called to the ACI, and they were called to supplement the state police who were already at their limits. ${ }^{418}$ In a phone call with the governor, Fagnant explained: “They'd rather be out of a job than

\footnotetext{
411 “ACI Guards Fired After Inmate Incident,” The Providence Evening Bulletin, July 16, 1974, A1.

${ }^{412}$ Ibid.

${ }^{413}$ Ibid.

${ }^{414}$ Ibid.

${ }^{415}$ Ibid.

${ }^{416}$ Ibid.

417 “ACI Guards Fired; Guardsmen Move In,” The Providence Journal, July 17, 1974, 1.

${ }^{418}$ Ibid.
} 
be killed or see a fellow officer hurt or killed in the line of duty."419 One officer stated: "What would have happened if he (Ward) had died?" 420 With the murder of Officer Price still fresh in their minds, they took their vow to make sure they protected each other to heart, as a true Brotherhood would do.

This was settled on the evening of July 17, as officers agreed to call off work stoppages "as a labor tactic" and Noel stated that he would rehire all of the officers that he fired the previous day. ${ }^{421}$ The governor reiterated the fact that inmates are entitled to a hearing before being placed into segregation, unless they are deemed dangerous. (This particular inmate was fighting with the officer in order to maintain possession of hacksaw blades, which many found to be reason enough to deem him dangerous.) The inmate was to be charged by the state police. ${ }^{422}$ While union officials had to accept this as a form of protection for the officers, rank and file officers were quite angry by the turn of events stating: “That's what you get for backing up a man who was assaulted-canned.” And "Inmates have all the rights and the officers have none."423 The union merely had to survive to fight another day and needed to accept the state police investigation as the only protection they would have in this kind of a situation. Many were concerned because the problems the union had still remained and they had made some serious concessions in the process. Work stoppages were a major tool to gain attention and action when nothing else would. In the end, the inmate who was charged did receive thirty days on the end of his

\footnotetext{
${ }^{419}$ Don Abood, “'They'd rather be out of a job than see an officer killed,'” The Providence Journal, July 17, 1974, A1.

${ }^{420}$ Ibid.

421 “ACI Accord Reached; Rehiring of Guards Set,” The Providence Evening Bulletin, July 17, 1974, 1.

${ }^{422}$ Ibid.

${ }^{423}$ Ibid.
} 
sentence, as mandated by the law. ${ }^{424}$ But now, the union would need to follow union grievance procedure instead of their more powerful tactics, militant tactics to make progress. $^{425}$

The next time an inmate assaulted an officer (in this particular case, two officers), he threatened to kill an officer and there were witnesses to see the event. ${ }^{426}$ Therefore, the administration acted with swiftness and placed the inmate in segregation pending a hearing, deeming him dangerous. Gene Fagnant was pleased with the administrative actions. ${ }^{427}$ The inmate (Salvatore Ventre) was sentenced to two years on the charges of kidnapping and assault with a dangerous weapon. ${ }^{428}$ It was still unclear what would occur if an officer was in the unlucky predicament of not having witnesses to corroborate their story.

The administration appeared to be making more concessions by allowing the NPRA to hold a Family Day on August $11^{\text {th }}$, with plans to hold one on the following month. ${ }^{429}$ Six hundred guests came into the prison to visit two hundred inmates. ${ }^{430}$ Officers were openly skeptical, feeling that the inmates had just been on their best behavior right before the picnic so that it would not be cancelled, like the previous year. $^{431}$ Even the inmates referred to the event as a "pacifier". ${ }^{432}$ Officers and administrators were extremely against such events due to the chaotic nature of them

\footnotetext{
${ }^{424}$ David Kobb, “Inmate Gets 30 Days for Assault,” The Providence Journal, July 19, 1974, A7.

425 "Guards Saw A Simple Issue, and Noel Had A Simple Answer," The Providence Journal, July 21, 1974, F1.

${ }^{426}$ Don Abood, “ACI Called Tense After 3 Guards Are Assaulted By a Young Inmate,” The Providence Evening Bulletin, August 8, 1974, A2.

${ }^{427}$ Ibid.

428 "ACI Inmate Sentenced to 2 Years," The Providence Journal, August 9, 1974, B10.

${ }^{429}$ David Korb, "It was just like a day at the beach but participants were in prison," The Providence Journal, August 11, 1974, B1.

${ }^{430}$ Ibid.

${ }^{431}$ Ibid.

${ }^{432}$ Ibid.
} 
and the complete lack of security or decorum that ensued. ${ }^{433}$ While the administration appeared to be taken a tough stance, it seemed as though they were still catering to the inmate groups (like the NPRA) as a means of maintaining control. That kind of control was not long lasting. It also put officers at risk with contraband being brought in. It was impossible for such a small officer staff to be able to supervise all activities and provide adequate security when eight hundred people are gathered in mass and six hundred of them have come in from the outside. This would pose a problem for officers right up through the administration of William Laurie (Assistant Director of Adult Services), who understood the problems that major events like this caused, and worked to shut them down. ${ }^{434}$

Violence continued to escalate after the Family Day, as predicted, and charges of brutality against the officers were brought to court. ${ }^{435}$ Warden Mullen attempted to regain control by ordering a general lock-up of all of the inmates. ${ }^{436}$ However, this did nothing to quell tensions as then four officers were attacked, most notably, one was stabbed and one scalded with hot coffee. ${ }^{437}$ This angered the inmates and they became more physically aggressive toward the officers. Largely, the lack of consistency in administrative response led to the increase in frustration among the inmates (in

\footnotetext{
${ }^{433}$ William Laurie, Interview with the author, May 3, 2011. Kenneth Rivard, interview with the author, March 29, 2011. ${ }^{434}$ Ibid.

435 “3 Guards Injured in Fight at ACI,” The Providence Evening Bulletin, August 15, 1974, A1. “ACI Prisoners Brutality Case Ruling is Near,” The Providence Evening Bulletin, August 15, 1974, B6. ${ }^{436}$ David Korb, "Mullen orders lock-up at ACI after stabbing, assault cases,” The Providence Journal, August 16, 1974, A1.

${ }^{437}$ Paul Giacobbe, “4 Guards Assaulted at State Prison,” The Providence Journal, August 20, 1974, B1. One of the inmates that was involved in the new assault was none other than Mr. Salvatore Ventre, the inmate who had already received two years for kidnapping and assault with a dangerous weapon. Ibid.
} 
addition to the officers). It was clear that this new way of dealing with violence would not work.

Administrative policy became even more haphazard as the year progressed. On September 15, in maximum security, an officer was assaulted and had his life threatened after a fight between two inmates. ${ }^{438}$ The officer involved quit directly after. The administration "spent several hours pleading with him [the inmate]" to go into a cell in the segregation unit. He was then allowed to wander back to his original cell. Inmates were locked up and correctional officers were ready for any impending trouble and were suited up in riot gear. The inmate involved then denied assaulting the officer, despite witnesses. Officials said that they would administer a lie detector test the following day. The officer who quit stated on his way out: "The brass are not sufficiently aware of the institution's problems." ${ }^{439}$ This demonstrated a true breakdown in the tough stance of the administration from the year before. It appeared to be inevitable that the officers would be thrust right back into the chaos that had previously existed, and now had promised to refrain from job actions to bring about change. It appeared as though their hard won gains, which were few and far between, were falling by the wayside.

In response to all of these threats and violent attacks on officers, RIBCO began a statewide drive for a union health and welfare fund. ${ }^{440}$ This was a great way to gain public support and also monetary strength as a union. In the earliest years, such fundraising was necessary to cover what the members were not receiving in benefits,

\footnotetext{
${ }^{438}$ David Korb, “Assault of ACI Official Leads to Confrontation, Lockup,” The Providence Journal, September 15, 1974, B13.

${ }^{439}$ Ibid.

${ }^{440}$ Don Abood, “ACI Guards Launch Health Fund Drive,” The Providence Journal, August 21, 1974, B1.
} 
particularly with regard to injury on the job. ${ }^{441}$ The officers were also determined to set up a fund for the family of Officer Price, in the form of a trust fund for his son. ${ }^{442}$ The officers, in a very noble gesture, explained to the public that: "We don't feel Mrs. Price got what she should have gotten.”443 They were extremely loyal to his memory and realized that they would need to remain united and vigilant on all fronts, both on an everyday scale and also with regard to the bigger picture to remain safe and secure. They realized that the Brotherhood also encompassed the families who sent their loved ones into literal battle every single day, and they worked to also protect these families.

Officers were also finding that charges by the inmates were now gaining validity within the court system. U.S. District Court Raymond Judge Pettine, who often ruled in ACI cases, determined that three officers had in fact committed brutality. ${ }^{444}$ President Fagnant replied that he believed this opened the doors to more inmate "harassment" of the officers within the realm of the courts. ${ }^{445}$ A probe that was ordered by the governor returned which stated that there was no "widespread brutality” within the ACI, despite the various claims of the inmates. ${ }^{446}$

The union who felt they had no other alternative requested a study regarding maximum security, suggesting that they were "so engrossed in [their] own problems [they were] not running the institution." ${ }^{447}$ All of the litigation, legislative committees, and studies prevented officers and the administration from working to

\footnotetext{
${ }^{441}$ Ibid.

${ }^{442}$ Ibid.

${ }^{443}$ Ibid.

${ }^{444}$ Duane Steele, “ACI Guards Expect More Charges,” The Providence Evening Bulletin, November 29, 1974, B3.

${ }^{445}$ Ibid.

${ }^{446}$ David Korb, "Brutality Probers Give Report to ACI Officials,” The Providence Journal, November 30, 1974, 8.

${ }^{447}$ David Korb, “ACI Guards Ask Study of High Security Unit,” The Providence Journal, December 1, 1974, B14.
} 
solve problems within the ACI. Also, it harmed labor relations between the workers and the employees. The officers of the union felt they were not supported by their administration. In asking for the report, they asked that the committee look into reasons why relations and security at medium security were significantly better while maximum security struggled and officers were seriously assaulted on a regular basis. The union hoped that the committee would discover that the problems were a result of "friction between administrators of maximum security and prison guards". ${ }^{448}$ Fagnant argued that procedure in maximum changed "day to day" while in medium, procedure was uniformly enforced. ${ }^{449}$ The union was angry due to the fact that disciplinary reports "often disappear[ed]" and the administration often reversed the decisions of the officers. ${ }^{450}$ Fagnant argued that this was causing "low morale" among the workers. ${ }^{451}$ In addition to this, it was argued that this lack of uniform enforcement of the rules was leading to the numerous assaults. ${ }^{452}$ Something needed to be done to remedy the impending disaster, and the union reverted back to some of its previous tactics to try to force action from the administration.

The year ended with a plan to transfer seventy two inmates out of maximum to the medium security building, while awaiting trial inmates would be moved back to maximum. ${ }^{453}$ This was proposed by the administration to remedy the chaos within maximum security. It seemed like a reasonable solution, however, the awaiting trial inmates did not agree. They refused to leave the building, in fear of vicious assaults

\footnotetext{
${ }^{448}$ Ibid.

${ }^{449}$ Ibid.

${ }^{450}$ David Korb, “Guards Union to Request a Probe of 'Chaos' at ACI," The Providence Evening Bulletin, December 7, 1974, D4.

${ }^{451}$ Ibid.

452 Ibid.

${ }^{453}$ David Korb, “72 Inmates Will be Transferred to Medium Security Unit,” The Providence Journal, December 16, 1974, B3.
} 
that would likely take place by maximum security inmates, and engaged in a hunger strike. $^{454}$ The year of 1975 began with a lawsuit on behalf of the awaiting trial inmates. The impending suit by these inmates was, after three days of testimony, dismissed due to the fact that the state did not have the funds to carry out the transfer of prisoners. $^{455}$

\section{5: Increasing Cooperation as the Path to Success}

Throughout the year of 1975, the union focused on working with the administration, as the administration made officer safety a higher priority. The officers and the administration had to work together to comply with court orders and to regain control. The year saw a dramatic increase in the amount of litigation and legislation regarding the inmates’ rights. The governor looked to institute a shorter work week for state employees to cut costs during the recession, which would be challenged and won by the union. The improvement in communication between the officers and the administration (both middle management and within the Department of Corrections) was crucial to progress throughout this year. Modified lockups were put into place with the assistance of armed state troopers, which helped to ensure the safety of the officers. Also, contract negotiations went well when compared with negotiations of the past. The union demands centered on benefits and the protection of the seniority clause. The administration seemed to gain a clearer sense of what direction they wished to take, which helped to make working conditions and labor negotiations better for all.

\footnotetext{
454 David Korb, “ACI Inmates Won’t Leave Building,” The Providence Journal, December 19, 1974, B1. "Hunger Strike At ACI,” The Providence Journal, December 22, 1974, B6.

${ }^{455}$ Hamilton Allen, “ACI Suit Moot - No Money,” The Providence Journal, January 30, 1975, A1.
} 
This was a year of economic downturn for the state of Rhode Island and the effects of this downturn were being felt on multiple levels of the state prison system. February 1975, was a month of a lot of action on a couple of fronts, in which a lack of state funds was demonstrated to be at the root of many of the problems at the ACI . The first front involved a lawsuit that was being filed against the governor and the Department of Corrections by the inmates, who believed that they were not provided with medical treatment or vocational and educational training. ${ }^{456}$ Secondly, the governor had also been considering a shorter work week and harsher penalties regarding overtime. ${ }^{457}$ This incited the rage of the union, and union officials argued that the cutback would hamper already limited operations within the prisons. ${ }^{458}$ One lieutenant that was interviewed argued that officers had to work overtime to keep the facility, which was understaffed, secure. They did not feel it was a luxury, but a burden. The union viewed the governor's order as unrealistic. ${ }^{459}$ The captains and lieutenants did not report to work in protest of the new orders from the governor's office. ${ }^{460}$ With a short-staffed institution now under even greater work constraints, the conditions for the inmates deteriorated and they rebelled. On February 27, 1975, inmates took over two areas of maximum security and officers had to lock themselves, and the civilian staff into a separate area of the prison to be safe. ${ }^{461}$ One control was regained, the administration tried to continue with normal routine. However, they

\footnotetext{
456 “ACI Inmates Sue State for Improvements,” The Providence Journal, February 8, 1975, 5.

457 "State Considers Short Work Week," The Providence Journal, February 1, 1975, 7.

${ }^{458}$ Paul Giacobbe, “After High Overtime, a Shorter ACI Work Week,” The Providence Journal, February 16, 1975, 11.

${ }^{459}$ Ibid.

${ }^{460}$ Paul Giacobbe, “Absences at ACI Called an Attempt to 'Break' Noel’s Austerity Program,” The Providence Evening Bulletin, February 25, 1975, B4.

${ }^{461}$ Paul Giacobbe and Dan Abood, "Disorders At ACI Flare Twice in Day,” The Providence Journal, February 28, 1975, A1.
} 
inmates then took over areas of the prison again. One hundred state and local police came into the prison in response, in both instances. A general lockup was ordered directly after the second incident. ${ }^{462}$ This proves that when funding was cut for these institutions, both the inmates and the officers suffered.

Officers brought the Noel order to court, asking that the court declare it void. ${ }^{463}$ They argued that it violated the collective bargaining agreement between the state and the union. They also argued that the order violated the constitutional rights of the officers with regard to due process and equal protection. In August, an arbitrator ruled that Governor Noel violated the terms of the correctional officers’ contract when setting the overtime rules, and thus ruled in favor of the union. ${ }^{464}$ The union was vindicated, although this would not solve all of the problems that existed before the order was put into place. Noel said that he would appeal the decision in the Supreme Court stating that "people out there think they can take a day off when they want and come back when they want”. 465 President Fagnant charged the governor with completely "distort[ing] the issues" and stated that "abuse of sick leave” should be punished, not "use of sick leave". ${ }^{466}$ Fagnant then stated: "Noel was elected Governor, not God...” “...If he wants a responsible labor organization, then the state must have responsible management."467

The governor's office and the Department of Corrections began to gain a clearer sense of direction throughout 1975. In April, Governor Noel submitted three

\footnotetext{
${ }^{462}$ Ibid.

463 "Void Noel Order, Six Petition in Court,” The Providence Journal, March 26, 1975, B1.

${ }^{464}$ Robert Stickler, “Prison Guards Win Fight for Overtime,” The Providence Journal, August 14, 1975, A1.

465 “Noel’s Governor, Not God, Fagnant Says,” The Providence Journal, September 5, 1975, A4.

${ }^{466}$ Ibid.

${ }^{467}$ Ibid.
} 
bills for ACI reform. One would offer opportunities for vocational training for inmates. Another would grant employment opportunities through private industries working within the ACI. Lastly, the third would grant furloughs up to fourteen days, for various reasons. ${ }^{468}$ While some of these reforms would bring in needed activity and productivity to the prison system, they also created some security hazards with regard to the lack of security that could result from private industries coming into and leaving the prison facilities each day as well as the issues furloughs created with regard to officer supervision.

At this point, the ACI entered into an era in which a great debate regarding the opening of new facilities ensued. The idea of a "Supermaximum" security prison was brought forth by Senator Joeseph W. Walsh, which would be funded by $\$ 7.5$ million in bond money. ${ }^{469}$ This idea was supported by RIBCO, which acknowledged that the "incorrigible" inmates of maximum needed to be brought under control before the prison could be reformed. ${ }^{470}$ Other plans were also proceeding forward with the development of an intake and diagnostic area as well as a separate space for awaiting trial inmates. ${ }^{471}$ In November, the ACI subcommittee to the Governor's Advisory Commission on Correctional Services recommended to the full commission that first priority be given to the construction of the intake/diagnostic center. ${ }^{472}$ These plans would require the public's approval (as they required a great deal of money), which would prove to be problematic in the following year.

\footnotetext{
${ }^{468}$ Paul Kelly, "Noel Submits 3 Bills on ACI Reform,” The Providence Evening Bulletin, April 2, 1975, A1.

469 “'Supermaximum’ Prison Backed by ACI Union,” The Providence Journal, September 18, 1975, A14.

${ }^{470}$ Ibid.

${ }^{471}$ Ibid.

472 “Priority Urged for Intake Center,” The Providence Journal, November 20, 1975, A26.
} 
Relations between Warden Mullen and the officers appeared to have greatly improved. Mullen, had recently instituted a series of lockup in response to violence (involving stabbings and assaults among inmates), and the union supported his actions thoroughly and publicly. ${ }^{473}$ Mullen advocated a partial lockup plan in which only a segment of the three hundred and fifty inmates would be allowed out of their cells at any one time. ${ }^{474}$ Fagnant argued that, for the situation to improve, the officers needed to support the warden, who had now taken a firmer stance. He was quoted as saying that the officers supported the warden in "his attempt to take control of the prison out of the hands of the inmate population and return it to the people responsible for running the prison. ${ }^{475}$

As the administration began to discuss plans for a further modified lockup plan (in response to the orders of Judge Pettine), the union threatened a walkout. ${ }^{476}$ The union felt the inmates were still not ready for a further modified lockup. Also, union officials felt the need to assert more control on the shop-floor and wanted to take back some control from the court system. Administrators met with officers and offered to them a chance to submit their own plans for ending the lockup. The lockup had been going on for two weeks, and thus was pushing the boundaries allowed by Judge Pettine. Some officers were unhappy with the lockup because, as inmates were fed in

\footnotetext{
${ }^{473}$ Paul Giacobbe, “Guards’ Union Head Back Warden’s Acts,” The Providence Evening Bulletin, November 5, 1975, 22.

${ }^{474}$ Ibid.

${ }^{475}$ Ibid.

${ }^{476}$ Paul Giacobbe, “ACI Guards In Near Walkout,” The Providence Evening Bulletin, November 12, 1975, D5.
} 
their cells, they threw trash, food, and other "debris" at the officers. ${ }^{477}$ The lockup was modified on November 13, with some of the suggestions put forth by the union. ${ }^{478}$

It appeared as though the administrators within the Department of Corrections began to realize the need to regain control before reforms could be implemented. As the modified lockup was put into place, fifty additional state troopers were on hand to assist with maintaining control. ${ }^{479}$ The troopers were armed. Donald Taylor, now acting director of the Department of Corrections, explained that the "archaic prison structure" was to blame for many of the problems within the prison. ${ }^{480}$ He stated:

“Those people who have been crying for rehabilitative programs - and I include myself among them - will have to realize that we must begin at the bottom and regain control first."

This shows a departure from the policies of the past and an understanding that reform and security do not necessarily go hand in hand. Security must be established before reform programs can be effective.

However, to do this, officials had to first demonstrate to the court (namely Judge Pettine), that the lockup was following his previous orders regarding prisoners’ rights and the conditions of the prison. ${ }^{482}$ In response to the correctional officials' bid to maintain the lockup, Judge Pettine warned that he would close the state prisons if they would not comply with his rulings. ${ }^{483}$ Acting corrections director Taylor,

\footnotetext{
${ }^{477}$ Ibid.

478 “ACI Lockup to be Modified,” The Providence Evening Bulletin, November 13, 1975, A1.

${ }^{479}$ Paul Giacobbe, “Modified ACI Lockup Calm; 100 Troopers, Guards Hover,” The Providence Journal, November 15, 1975, 1.

${ }^{480}$ Ibid.

${ }^{481}$ Ibid.

482 "Court Hearing Today on New Lockup at ACI," The Providence Journal, December 2, 1975, A6.

${ }^{483}$ Hamilton Allen, “Judge Warns He May Close State Prison,” The Providence Journal, December 3, 1975, A1.
} 
consistently stated that the antiquated facilities made it impossible to run "proper prisoner programs". ${ }^{484}$ He also argued that the staff did not have the "luxury" of being able to separate the instigators from the other inmates, and thus, the conditions had to be imposed on the entire population. ${ }^{485}$ More importantly, this shows that the union would not shy away from challenging the courts.

RIBCO held an election in November, for another two year term. Running unopposed were Gene Fagnant for president, Albert Gardiner for first vice president, Alan Silverman for treasurer, and Kenneth Rivard for financial secretary. Louis Ward was elected second vice president and Edward Petrarca was elected recording secretary. ${ }^{486}$ The fact that four of these men ran for positions unopposed suggests a high degree of satisfaction with the leadership on the part of the membership.

The union, up to this point, had greatly increased the pay scale of the officers. Now the union officials began to work on increasing the benefits of the officers. RIBCO had been in contract negotiations since June, to no avail. In December, union officials walked out of a meeting with state negotiators, when the negotiators withdrew an offer that had previously been agreed upon. ${ }^{487}$ Three major items were included within this: a fifteen minute briefing before the start of the shift (on overtime pay), a shift differential increase, and three paid personal days. ${ }^{488}$ Again, talks between the union and state officials failed on the $19^{\text {th }}$ of December. ${ }^{489}$ This time, negotiators for both sides were stuck on the seniority clause, which the state argued

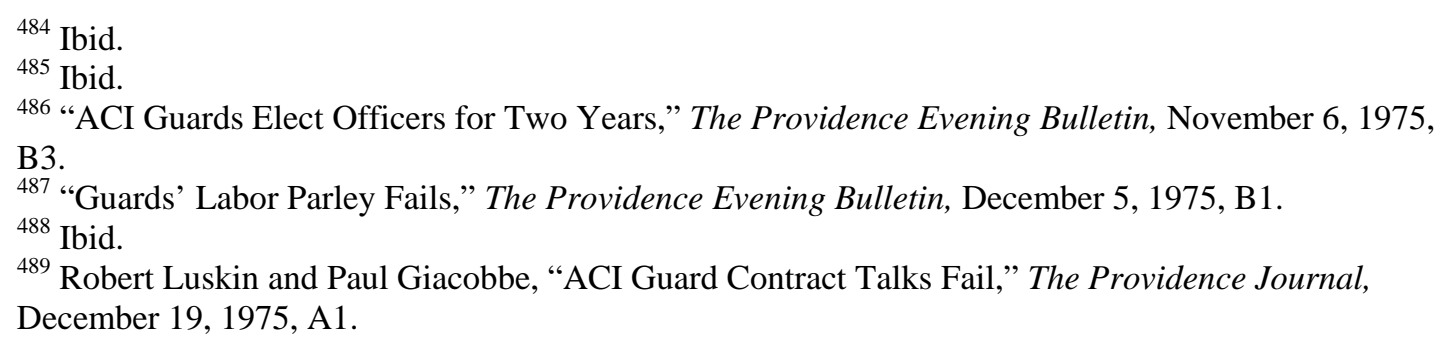


that the clause must be eliminated. Attorney for the union, Gerard Cobleigh argued that the state should show specifically how the clause would affect the operation of the prison. ${ }^{490}$ This clause was the basis for all union rules regarding bidding for jobs, bidding for shifts, and anything else that could be chosen by the worker. Union members stood firmly behind this principle as being the fairest way to conduct business within the prison. Eventually the union and the state came to an agreement which increased the benefits of the officers and left the seniority clause intact, which was a victory for the union. ${ }^{491}$

\section{6: Perseverance in the Face of Adversity}

The year of 1976 saw a continuation of many of the same financial dilemmas and racial tensions of the past. As racial tensions escalated within the prison, confrontations between officers and inmates were inevitable (if only because most of the staff was white). Officers were caught in the middle of battles between prisoners and often caught the brunt of the violence. The public, during this economic recession, refused to offer any means of economic support and voted against various bond issues that would improve the infrastructure of the institutions. Until the public got on board with the administration and the officers' union, the system remained in a state of controlled chaos.

As with every other public sector union during times of fiscal crisis, state legislators began to launch more frequent attacks regarding extra money being spent on the workers. The union came under fire again on sick leave, as legislators argued

\footnotetext{
${ }^{490}$ Ibid.

${ }^{491}$ Paul Giacobbe, “ACI Guard Pact Insures Overtime,” The Providence Evening Bulletin, March 25, 1976.
} 
that private industry did not have nearly the same amount of sick time being taken. ${ }^{492}$ The union, in response, attacked these legislators as "ill-informed people who make irrational statements” about prisons and what goes on in the ACI. ${ }^{493}$ He also argued that Temporary Disability Insurance (TDI) was not available to state employees, because they did not pay into the state insurance system. ${ }^{494}$ It should also be noted that the high degree of assaults does not occur in any other job atmosphere due to the nature of the work.

A special legislative committee was established to answer questions as to why there was still so much money being spent on overtime. ${ }^{495}$ Two years previously, ninety seven officer positions were created. However, one year previously, the administration had created thirty two posts beyond what was authorized. The overtime issue appeared to be an administrative problem. Also, officers were still undertaking tasks that were out of their skill set, such as delivering mail, reception work, working in the clothing room, working in the general store, or driving the trucks of materials. ${ }^{496}$ Also, studies on the effective use of officers were drawn up but then never used by the Department of Corrections. ${ }^{497}$ Strong union personality Hector Poulin, grievance chair for RIBCO at the time, argued that the high overtime was "not the result of games being played by correctional officers.”498 The legislative

\footnotetext{
${ }^{492}$ Paul Giacobbe, “ACI Sick Leave ‘Racket’ Charged,” The Providence Journal, February 12, 1976, B1.

493 “Union Defends Itself on Sick Leave,” The Providence Journal, February 13, 1976, A14.

${ }^{494}$ Ibid.

${ }^{495}$ Paul Giacobbe, “Tighter ACI Job Controls Urged,” The Providence Journal, March 4, 1976, A18. ${ }^{496}$ Ibid.

${ }^{497}$ Paul Giacobbe, “3 Overtime Studies on ACI Never Used” The Providence Journal, March 25, 1976, B4. ${ }^{498}$ Ibid.
} 
committee chair, Robert Sweeney, asked Poulin to make some recommendations to the committee as to modifications that could be made. ${ }^{499}$

Internally, the year of 1976 provided some structural changes for the union. In March, President Gene Fagnant left the ACI to go to work for Council 70 of the American Federation of State, Country, and Municipal Employees. ${ }^{500}$ Ironically, this is the same Council 70 that the Brotherhood had left to create an independent union. Albert Gardner took the place of acting president of the guards’ union.

Also in 1976, the issue of sex-bias between facilities became a hot-button topic. Gloria McDonald (a lieutenant) was first on the list for promotion to captain and informed her superiors that she would expect a promotion when a vacancy opened up, even if it was in the maximum security section. ${ }^{501}$ At that time, maximum security was an all-male facility and the staff was entirely male. Many feared that, with the checkered past of the facility, a female officer was at more risk within the facility (particularly with regard to sexual assault). Many, including those on the Equal Employment Opportunity Commission, argued that male nurses, instructors, counselors, and therapists were allowed to work in the women's facility and thus, females should be allowed to work in the all-male facility. ${ }^{502}$ Equal employment opportunities would be brought to fruition in 1979, when the union supported grievances on behalf of senior female officers (in accordance with the seniority principle).

\footnotetext{
499 Ibid.

500 “'Guards’ Union President Takes Council 70 Post,” The Providence Journal, March 19, 1976 , B4.

${ }^{501}$ Paul Giacobbe, “ACI Officials Worry About Sex-Bias Issue,” The Providence Evening Bulletin, May 10, 1976, B1.

502 Ibid.
} 
The unrest within the prison was far from dissipated. New members of middle management made a difference in how unrest was handled, however. In July of 1976, the union (under the leadership of Albert Gardner), requested a meeting with the Department of Corrections to discuss the growing unrest among inmates. ${ }^{503}$ Another lockup was imposed due to concern over inmates arming themselves with items such as swords and clubs. ${ }^{504}$ It is because of this that William Laurie, new assistant director of corrections for adult services at the time (with all of the rights and responsibilities of a warden), ordered the lockup and also had no qualms about calling the state police whenever there was an uprising. ${ }^{505}$ He argued that there were four hundred inmates, who were armed, up against twenty officers (if that) in an open area, armed merely with a whistle. ${ }^{506}$ He knew the officers would not stand a chance. ${ }^{507}$ In an attempt to gain the confidence of the officers and create a better working relationship with them, he would always go into a hazardous situation with them. ${ }^{508}$ This helped to further improve relations between management and the workers, as Laurie provided an example of an administrator who would not ask workers to do something that he was not willing to do. He was willing to literally stand with the officers in the face of

\footnotetext{
${ }^{503}$ Terry Schwadron, “Guards Ask Meeting Over ACI 'Unrest,”’ The Providence Evening Bulletin, July 19, 1976, A6.

${ }^{504}$ Paul Giacobbe, “Arms Alarm Causes ACI Inmate Lockup,” The Providence Journal, July 20, 1976, A1.

Pictures from the personal collection of William Laurie.

${ }^{505}$ William Laurie, interview with the author, May 3, 2011.

Laurie was appointed by Director Southworth and as it was termed by scholar Leo Carroll, "It was left to his [Southworth's] assistant Bill Laurie, to wrest power from the inmates and reinvest it in the officers."

Carroll, Lawful Order, 111.

${ }^{506}$ Ibid.

${ }^{507}$ Ibid.

${ }^{508}$ Ibid.

He also, when talking with correctional experts, would bring officers with him (such as Hector Poulin), who knew their own system intimately and could assess the positives and negatives that various recommendations had to offer.
} 
conflict, which was rare and yet created a great deal of respect between middle management and the workers.

Conflict was inevitable without any major structural change. A melee broke out in August, across racial lines. ${ }^{509}$ African American inmates accused white inmates and white officers of setting up the situation. Seven inmates were confined to segregation following the fighting. The American Civil Liberties Union argued for a full, public investigation of the incident. ${ }^{510}$ Governor Noel appointed a commission involving all outside members, due to the charge that the officers themselves were involved. ${ }^{511}$ The claims of racial conspiracy were later ruled to be unfounded. ${ }^{512}$ As a result of the explosive situation, a minor riot occurred on August $8^{\text {th }}$, in which eleven inmates and three officers were injured. ${ }^{513}$ In addition to the racial tensions (both between officers and inmates and between inmate groups), overcrowding was also becoming a factor in the escalating tensions. ${ }^{514}$ As racial tensions died down in later years, overcrowding provided the cause for inmate rebellion. Though the rebellions would not be as frequent, they were still major, violent, and destructive. The only way to fix this was with money to provide a better infrastructure and badly needed programs.

October and November were important months as the upcoming elections decided major bond issues for the ACI. A\$13.9 million bond issue was put up for the

\footnotetext{
${ }^{509}$ Thomas Morgan, “Black Inmates See White Plot in Racial Row,” The Providence Journal, August 4, 1976, B1.

${ }^{510}$ Ibid.

${ }^{511}$ John Hackett and Ron Winslow, “Action Vowed Today In Racial Brawl at ACI,” The Providence Journal, August 6, 1976, B1.

${ }^{512}$ Terry Schwardron, “'No White Conspiracy’ Uncovered in Probe of Racial Brawl at ACI,” The Providence Journal, August 7, 1976, 32.

513 “ACI Prisoners, Guards Injured in 'Minor Riot,'” The Providence Journal, August 8, 1976, A1.

${ }^{514}$ Pail Giacobbe, “ACI Inmates Score Crowded Conditions,” The Providence Journal, September 11, 1976, 5.
} 
voters' decision and would provide improvements to the facilities as well as better treatment of inmates awaiting trial. ${ }^{515}$ Many argued that a newly instituted lockup was linked to the impending referendum vote. ${ }^{516}$ The bond did not pass. ${ }^{517}$ In addition, jobs within the ACI for inmates were hurt by federal statutes that prohibited goods produced by inmates from being shipped out of state, which hurt local industries. ${ }^{518}$ Any gains that were made were being hindered by bonds not passing or federal statutes. The year ended in a state of disillusionment and dismay on the part of the officers and the administration alike.

\section{7: The Beginning of Change}

The year of 1977 was the last in the series of formative years. The Department of Corrections, the governor, the middle managers, and the union appeared to be largely coming together on major issues and found that the only way that change would come about was through a significant increase in the resources available to the prison. The public appeared to recognize this unity and organization and began to trust that their money would be well-spent by those in charge of the ACI.

The year was characterized by the new gubernatorial leadership of Joseph Garrahy. Governor Garrahy promised, as a key position within his inaugural address, that "rehabilitation is the key objective of our correctional efforts". 519 The federal Treatment Alternatives to Street Crime threatened to withdraw money for the four drug counselors it was funding at the ACI if the administration did not make some

\footnotetext{
515 “Bond Issue for ACI Backed by Chiefs,” The Providence Journal, October 10, 1976, A7. “\$13,9 Million Bond Sought for ACI,” The Providence Evening Bulletin, October 27, 1976, A2.

${ }^{516}$ Paul Giacobbe, “Lockup Linked to Referendum?,” The Providence Evening Bulletin, October 27, 1976, D4.

517 "Where does long range planning for the ACI go from here?," The Providence Journal, November 11, 1976, A30.

518 “ACI Job Efforts Hurt By Statute,” The Providence Journal, December 13, 1976, A5.

519 "Policy Test at ACI”, The Providence Journal, December 7, 1977, A14.
} 
serious headway with regard to a decent drug program by the beginning of March. ${ }^{520}$ While they had the space for such a program, it was argued that they needed additional officers to staff the unit. Garrahy, however, felt that they could meet the TASC demands without hiring new personnel. ${ }^{521}$ Also, directly after taking office, Governor Garrahy approved a \$300,000 appropriation for a permanent maintenance unit for the ACI (including plumbers, carpenters, and electricians). ${ }^{522}$ Garrahy was also trying to hold onto a \$60,000 grant from the Law Enforcement Assistance Association, which also threatened to withdraw its money if they did not meet federal guidelines regarding drug treatment. ${ }^{523}$

A majority of the problem facing Governor Garrahy was the public’s lack of faith in the correctional system. In an interesting article by Bob Wyss (of April 1977), Wyss summed up the confusion in the following paradox: "The ACI a 'Country club' or a hellhole?"524 This captured the essence of the arguments on both the officers' side and the prisoners' side. On one side, state police Sergeants were testifying that prisoners had hot plates and were cooking lobster tails regularly. They also had small refrigerators, coffee urns, radios, and television sets. In addition to this, they used the NPRA telephones to create a bookmaking operation. On the other side, inmates claimed that conditions were appalling and they were beaten and gassed. They believed their punishments constituted "cruel and unusual punishments" under the law. Courts mandated that inmates have a life that was comparable to what it would

\footnotetext{
520 “Don't Need New Guards to Get Funds,” The Providence Journal, February 4, 1977, A4.

${ }^{521}$ Ibid.

522 "Policy Test at ACI,” The Providence Journal, December 7, 1977, A14.

${ }^{523}$ Ibid.

${ }^{524}$ Bob Wyss, “The ACI: A ‘Country club’ or a Hellhole?,” The Providence Journal, April 10, 1977, C1.
} 
be like outside of the walls. ${ }^{525}$ The public was left genuinely confused by all of the mixed messages they were receiving from the inmate organizations, the administration, politicians, and the officers. The officers would suffer if they could not all gain the public as allies in their struggle because of this confusion.

In response to all of the misperceptions, RIBCO asked that house legislators actually visit the ACI. ${ }^{526}$ This invitation was extended by the union to members of the House Finance Committee who questioned overtime payments for staff briefings. These meetings, as explained by Kenneth Rivard (vice president and spokesperson for RIBCO at the time), were crucial to the ongoing daily operations within the prison. They kept the officers updated on any unrest or disturbances and helped significantly with officer safety. Rivard explained that between 8 am and 9 pm the South State Wing, which contains four cellblocks and three hundred and twenty four inmates, was manned by only six officers (and some nights only four). He felt that legislators clearly had inaccurate information, based on some of the "misleading” statements that they had made, and he felt they should be offered an opportunity to obtain some accurate information. ${ }^{527}$

At the same time, Theodore Gordon (a specialist in institutional hygiene from Washington D.C.) found the prisons to be unfit for human habitation. ${ }^{528}$ Judge Pettine then went to the facilities himself and agreed with this assessment. Gordon explained that the major problem lay in the "age and design of the institution". ${ }^{529}$ Inmates

\footnotetext{
${ }^{525}$ Ibid.

526 "Guards Ask House Unit to Visit ACI,” The Providence Journal, April 12, 1977, A6.

${ }^{527}$ Ibid.

${ }^{528}$ Hamilton Allen, "Prison Expert Says ACI Unfit for Human Habitation,” The Providence Journal, April 14, 1977, B1.

${ }^{529}$ Ibid.
} 
claimed they lacked supplies for cleaning. William Laurie, while testifying before the judge, explained that he was in favor of replacing maximum security. ${ }^{530}$

Governor Garrahy, in a press conference, blasted the courts by stating that his workers spend more time within the courthouse than at work. ${ }^{531}$ He explained that he found ways to provide money for the system and that they were beginning to "turn the corner."532 Directly following this, the officers quit the panel established by Pettine, arguing that they had their own grievances with the Department of Corrections and did not have the time to be able to participate in such a panel. ${ }^{533}$

Apparently those grievances pertained to cutbacks. The Department of Corrections announced, on May $19^{\text {th }}$, its intention to reduce the number of officers assigned to each shift. ${ }^{534}$ In response to this, inmates and the union united to protest the reduction in staff. ${ }^{535}$ Officers argued that this would leave them open to attacks and explained that if they wished to cut costs, they should begin with administrative costs. ${ }^{536}$ The union filed a complaint of unfair labor practices against their employer for failing to abide by the binding arbitration within their recent contracts. This may have served to prove to the public that the Department of Corrections was fiscally responsible. Also, it is important to note that the union kept the confrontation from turning to job action, by filing the complaint of unfair labor practices instead of

\footnotetext{
${ }^{530}$ Hamilton Allen, “ACI Chief Would Replace Maximum Security Unit,” The Providence Journal, April 20, 1977, B4.

${ }^{531}$ Paul Kelly, "Garrahy Hits Time in Court," The Providence Evening Bulletin, May 12, 1977, B1. ${ }^{532}$ Ibid.

${ }^{533}$ Hamilton Allen, “Guards at ACI Quit Panel Appointed By Pettine to Study Prisoners' Suits,” The Providence Evening Bulletin, May 18, 1977, D1.

${ }^{534}$ Thomas Morgan, “ACI Guard Cutback Planned; Saving Set at \$7,000 a Week,” The Providence Journal, May 19, 1977, B1.

${ }^{535}$ Terry Schwardron, “ACI Inmates, Guards Join Forces In Opposing Reduction of Staff,” The Providence Journal, May 21, 1977, 22.

${ }^{536}$ Ibid.
} 
turning to more extreme action. This created a sense of stability and a better working relationship between the union and management.

Voters responded to the conditions within the ACI and the new working relationship of the administration and the officers and approved \$6 million for an intake service center. ${ }^{537}$ Also, on June 27, construction for a Supermax facility began. ${ }^{538}$ Finally the ACI was receiving the critical help it needed. Despite the positive developments, there was another three hour revolt at the ACI in August. ${ }^{539}$ The armed response to the revolt was termed by many politicians as an "overreaction”, which was also played up by the media. ${ }^{540}$ In response to the probe, William Laurie walked out on the Senate probe led by Senator Fortunato, and was cheered on by thirty correctional officers who went to support him. ${ }^{541}$ What was not released to the general public was that William Laurie was directed to walk out on the probers by the governor's office. ${ }^{542}$ This incident was projected by the media as a demonstration of the irresponsibility of the prison personnel. ${ }^{543}$

This was also a time of internal strife for the Brotherhood. Michael Solitro, who had previously run for second vice president in November of 1975, was now running for the presidency of the officer union. ${ }^{544}$ Solitro was a controversial figure

\footnotetext{
537 Joel Sekers, "Voters OK bonds for roads, prisons," The Providence Journal, June 29, 1977, A1.

538 "Ground Broken for Construction of Supermax," The Providence Evening Bulletin, June 27, 1977, A20.

539 “4 Are Injured In Three-hour Revolt at ACI,” The Providence Journal, August 27, 1977, A1.

${ }^{540}$ Robert Stickler, “Garrahy Asks Probe of ACI 'Overreaction,”’ The Providence Journal, August 29, 1977, A3.

${ }^{541}$ Stephen Morin and John Kiffney, "Laurie Walks Out On ACI Probers,” The Providence Journal, August 31, 1977.

${ }^{542}$ William Laurie, interview with the author, August 3, 2011.

${ }^{543}$ Stephen Morin and John Kiffney, "Laurie Walks Out On ACI Probers,” The Providence Journal, August 31, 1977.

544 “ACI Guards Elect Officers for 2 Years,” The Providence Evening Bulletin, November 6, 1975, B3. Tom Gariepy, “Solitro Seeks Presidency of Guards' Union At ACI,” The Providence Journal, August 2, 1977, A8.
} 
within the union. A week prior to seeking the candidacy of the union, Solitro delivered a letter to the governor himself, protesting the conditions within the prison. ${ }^{545}$ This letter stated: "We [the guards] cannot accept the unnecessary burden of our lives being put in jeopardy by sheer incompetence on the part of the current administration of the Department of Corrections..546 During this same time, new Corrections Director Southworth had admitted that the inmates still exercised a great deal of control over the facility. ${ }^{547}$ Solitro argued that some members were "dissatisfied" with the way that the union had dealt with the problems in the prison. ${ }^{548}$ He argued that officers were being threatened by inmates (threats regarding themselves and their families) and put in compromising situation, which forced them to comply with inmates demands for favors. ${ }^{549}$ It is unclear what exactly Solitro would change upon assuming the presidency of the union. In the meantime, the union (under the presidency of Kenneth Rivard), had recently submitted a request to meet with Southworth to discuss the issues still facing officers’ safety within the facilities and the conditions within the facility at that time. ${ }^{550}$ In response to Solitro’s charge that officers were coerced into granting the favors of inmates, Rivard explained that: “The guards' have nothing to give." ${ }^{, 551}$ He argued that if prison rules were being

\footnotetext{
545 Thomas Walsh, “ACI Guard Brings Letter to Governor: Warns Jail 'could explode any time,”” The Providence Journal, July 30, 1977, 1.

${ }^{546}$ Ibid.

${ }^{547}$ Ron Winslow and Gina Macris, “Prisons Head Acknowledges Inmates’ Sway,” The Providence Journal, August 1, 1977, A1.

${ }^{548}$ Tom Gariepy, “Solitro Seeks Presidency of Guards’ Union At ACI,” The Providence Journal, August 2, 1977, A8.

549 Ibid.

${ }^{550}$ Tom Gariepy, “Officials of ACI Guards Union Will Meet With Southworth,” The Providence Journal, August 3, 1977, A8.

${ }^{551}$ Ibid.
} 
broken and inmates were receiving favors, such as furloughs, the favors had to come from the administration and not the officers themselves. ${ }^{552}$

Concurrently, Rivard also launched an attack on the rulings of Judge Pettine. ${ }^{553}$ Pettine had issued an extensive order to correct the conditions within the prisons on August 10, 1977. ${ }^{554}$ Rivard spoke out against four major points: the charge that officers were a major source of the drug problem at the ACI, the criticisms of the medium security building, the proposal of a human rights commission that would be allowed to transfer personnel, and the time limits set on the state for accomplishing the various reforms put forth. ${ }^{555}$ Pettine also ordered that no contract between the ACI and the union be signed until he had a chance to review it and make some changes. ${ }^{556}$ While the rulings of Judge Pettine ultimately helped to change the conditions at the ACI, many criticized him for insinuating himself in areas that the judiciary should not be involved in, such as labor negotiations.

In 1979 and 1980, the short-lived presidency of Michael Solitro caused the union a lot of grief and discord. Solitro fired factions of the union who did not agree with his philosophies. In addition to this, he ignored the union's request that he not meet with administrators alone regarding contract negotiations, on his own personal time. The union felt that compromised the integrity of the Brotherhood and their bargaining unit. He continued to have administrators over to his home for dinner. The

\footnotetext{
552 Ibid.

${ }^{553}$ Tom Gariepy, “ACI Guard Union Head Attacks Pettine Ruling,” The Providence Journal, August 12, 1977, A29.

${ }^{554}$ Leo Carroll, Lawful Order : A Case Study of Correctional Crisis and Reform, New York : Garland Pub., 1998, 3.

${ }^{555}$ Tom Gariepy, “ACI Guard Union Head Attacks Pettine Ruling,” The Providence Journal, August 12, 1977, A29.

${ }^{556}$ Stephen Morin, “Pettine to Oversee Pact Between ACI and Guards' Union,” The Providence Journal, November 16, 1977, A1.
} 
union was informed of this and decided to hold a trial board in October of 1980 regarding these new developments. The board voted to oust Mr. Solitro from the presidency of the union. ${ }^{557}$ At this point, Ronald Brodeur was brought in as the union president for seven years, from 1980-1987.

In addition to these big developments regarding new construction, court mandates, and the internal strife of the union, Corrections Director Southworth was directed (by a special Senate committee that was investigating the ACI) to establish more stringent rules with regard to press access to the ACI. ${ }^{558}$ This would lead to a huge crackdown on press access to the prisons and ultimately would ease tensions between different factions of the correctional system of Rhode Island. The crackdown would be continued throughout for the decades to come.

This entire formative era unified the officer's union and solidified the priorities of the officers. RIBCO made officer safety its top priority, and brought this to the forefront of the concerns of the administrators. During a time in which violence was escalating in prisons throughout the nation, the officers learned that they needed to band together (despite internal differences) and present a united front to accomplish their goals. The union, sometimes successfully and sometimes not, appealed to the public and managed to make itself a visible facet of the ACI machinery and a strong faction to contend with. Union leadership maintained a sense of union militancy, yet not to the detriment of relations between the administration and the workers. The end

\footnotetext{
${ }^{557}$ Kenneth Rivard, Phone interview with the author, March 6, 2012.

“ACI Guards Vote to Suspend Union Head Pending Hearing,” The Providence Journal, September 26, 1980, C7.

“Guard Union Trial Board Fires Suspended President Michael Solitro,”The Providence Evening Bulletin October 3, 1980, A9.

${ }^{558}$ Bob Wyss, “Southworth Must Make Plan for Press at ACI,” The Providence Journal, June 28, 1977, A1.

“Keeping a Gag on the ACI,” The Providence Journal, October 29, 1977, A22.
} 
of this era saw a great improvement in communication with the administration, which would help in bringing about change. 


\section{CHAPTER 5}

\section{Path to Order}

\section{0's: The Age of Conservatism}

The themes of the 1980's were apparent as early as 1978 for the Rhode Island Brotherhood of Correctional Officers. This time period was characterized by two specific movements. The first was the wave of conservatism that was sweeping the nation. This led to a severe crackdown on the labor front and many unions did not survive this era successfully. In addition to this, in the State of Rhode Island, this was an era of extreme judicial involvement in prison reform. This would mean attacks on the Rhode Island Brotherhood of Correctional Officers, both with regard to the political climate of the times and the difficulties that prison reform held for the officers. However, it was through this judicial intervention that conditions within the prisons improved, as did the working environment for the officers involved. This led to a fundamentally better relationship between the officers and their administration. Despite the challenges on the political front and with regard to implementing reforms, RIBCO maintained the progress that it had made throughout the 1970's and built upon them throughout this new age of conservatism. The union did this through maintaining a public presence, growing in size, consistently improving contracts, and maintaining solidarity through internal communication.

The 1980’s under the Republican presidency of Ronald Reagan, ushered in a wave of conservatism and a sentiment of anti-labor and a crackdown within the War on Drugs. Poor and working class voters all but disappeared on the political scene, 
disillusioned with the direction of government since the Vietnam War and Watergate. This left only conservative voters making all of the decisions for the nation. With the rise of the so called "New Right," there was a staunch revolt against taxation. This would only serve to harm those working in the public sector. What would later be termed "Reaganomics," cut taxes, government regulations, and social spending. This widened the gap between the rich and the poor and made it difficult to fund federal programs which were needed in state prisons. The labor movement was attacked throughout this conservative backlash. Layoffs and plant closings within "heavily unionized industries” and traditionally blue-collar manufacturing strong-holds depleted the labor movement of its stauncher elements. ${ }^{559}$ Unions became "weak" and leaders became reluctant to take on any major battles. ${ }^{560}$ Also, employers, in the latter half of the 1970s became much more aggressive in their union busting techniques. Wages were consistently cut across industries in response to the economic recessions of the late 1970s. As the labor movement entered the 1980s, it lost all of the fervor and momentum that it had once contained in the early part of the 1970s. In addition to this, President Reagan made it is personal mission to take on the public sector unions, as evidenced by his union-busting actions during the PATCO (Professional Air Traffic Controllers Organization) strike. This helped to set a national tone for the public with regard to public sector unions. Unions entered a period of "concession bargaining," just attempting to survive this conservative era. ${ }^{561}$ The labor movement retreated and had fractured, in large part due to its unwillingness to back minorities and its failure to merge with the civil rights movement.

\footnotetext{
${ }^{559}$ Who Built America, 724.

${ }^{560}$ Ibid.

${ }^{561}$ Who Built America, 698.
} 
At the same time, this was a time of judicial intervention within the prisons and it was a success overall. The legal basis of intervention comes from the Eighth Amendment (which makes it illegal to institute cruel and unusual punishments), in which a "totality of conditions" warrants judicial intervention. ${ }^{562}$ The basis for intervention in the state of Rhode Island came from the case Palmigiano v. Garrahy (1974), which resulted in a class-action suit. The suit claimed that the state was denying adequate medical care and failed to classify inmates properly. Conditions, that were difficult for the officers who worked within the facilities, were intolerable for those who lived within them. These horrid conditions were the cause of many of the escalating tensions and disturbances throughout the late 1970's and 1980's. In 1977, Judge Pettine issued a decree with standards and deadlines for instituting proper recreation, education, and treatment programs. It specified areas of concern with regard to physical conditions and mandated that inmates be reclassified. Allen Breed was then appointed "special master”, in place of the human rights committee established by Pettine. ${ }^{563}$ It was decided that, since the High Security Center (Supermax) and the Intake center would take a long time to be completed, the Department of Corrections should make every effort to make maximum security habitable. $^{564}$

The Department of Corrections still needed to decide how to best approach security while the buildings were being built and updated. The fight for control of the facilities was still a daily struggle. Also crucial to this decade was the strong leadership of new Corrections Director, John Moran. John Moran, who replaced

\footnotetext{
${ }^{562}$ Carroll, Lawful Order, 127.

${ }^{563}$ Carroll, Lawful Order, 128-138.

${ }^{564}$ Carroll, Lawful Order, 186-187.
} 
Southworth as Corrections Director in the beginning of February 1978, helped to lead the charge in securing the prison and instituting reforms. ${ }^{565}$ With his strong leadership, Breed became less directly involved as "special master" and became a monitor of the situation at hand. ${ }^{566}$

Moran, having been heavily involved in corrections himself for many years, understood the changes that needed to be made. On Febuary 22, 1978, Moran came out publically against inmate organizations, such as the NPRA ${ }^{567}$ During this time, a lockup had been instituted. ${ }^{568}$ In April 1978, the officers and inmates engaged what is known as the "Garbage Wars". ${ }^{569}$ As inmates were locked up, they continued to create a mess by throwing trash and other debris from their cells in protest. ${ }^{570}$ Officers and private contractors came in to clean up the two to three feet of trash that had accumulated. ${ }^{571}$ This was an extremely critical turning point for the officers and the inmates, according to retired captain Ronald Brodeur. ${ }^{572}$ It helped to establish the fact that the officers were taking back control from the inmates. ${ }^{573}$ These "Garbage Wars" lost the NPRA any support that it had. ${ }^{574}$ Also critical to this period was that the

\footnotetext{
${ }^{565}$ Stephen Morin, "The New Prison Boss is No Stranger to the Toughest Job in Town,” The Providence Journal, February 5, 1978, A1.

${ }^{566}$ Carroll, Lawful Order, 153.

567 “Moran Opposes NPRA at ACI; Discloses Drunk Driving Arrest,” The Providence Journal, February 22, 1978, A4.

${ }^{568}$ Carroll, Lawful Order, 154-155.

${ }^{569}$ Ronald Brodeur, interview with the author, March 17, 2011; and Photos from the personal archives of William Laurie, Rhode Island Brotherhood of Correctional Officers..; and Photos from the personal archives of Ronald Brodeur, Rhode Island Brotherhood of Correctional Officers.; and Carroll, Lawful Order,156; and "3 Inmates Tell About 'Garbage War,'” The Providence Evening Bulletin, August 1, 1980, A5.

${ }^{570}$ Ibid.

${ }^{571}$ Ibid.

${ }^{572}$ Ronald Brodeur, Interview with the author, March 17, 2011.

${ }^{573}$ Ibid.

${ }^{574}$ Carroll, Lawful Order, 156.
} 
governor declared the prison to be under a "state of emergency," which allowed a few of the more "hardcore" inmates to be transferred out of state. ${ }^{575}$

John Brown was appointed warden at this time. He was a recently retired corrections veteran appointed by Moran. Also, he had spent a good deal of time working as a security consultant. Brown was in charge of the operations within the prison on a day to day basis (while Moran devoted his time to finding resources, planning, and overseeing new facilities). The first thing Brown did was to put into place an established chain of command for grievance proceedings. He also published a manual of rules and regulations for the inmates and instituted an extended preservice training for the officers. He made it a point to work closely with the officers themselves. This change in middle management was extremely helpful to the officers and the union who were looking for experts who had worked within the prison conditions themselves and understood the internal dynamics of working within a prison. $^{576}$

Also, in 1979, the Brotherhood brought grievances on behalf of female officers denied positions in an all-male facility, to protect the seniority principle which governed all union activities. They were extremely successful in winning each of the cases they defended. By 1981, the facilities were no longer divided along gendered lines. ${ }^{577}$ Female officers were now allowed to work in all male-facilities, and vice versa. Also in the early 1980's, the union maintained a deep commitment to the principle of seniority. In the summer of 1980, the administration hired one hundred and thirteen new officers (three of which were new captains and six were lieutenants)

\footnotetext{
${ }^{575}$ Carroll, Lawful Order,156-157.

${ }^{576}$ Carroll, Lawful Order, 162-163.

${ }^{577}$ Carroll, Lawful Order, 166.
} 
to staff the new High Security Center. They believed that this bidding process for these new positions violated the contract that they had with the ACI, as other more senior officers did not have an opportunity to bid into these positions. The administration redid the bidding, at the request of the union, without any job action or arbitration. ${ }^{578}$

At this point, six programs were brought into effect without any major problems. The number of inmates in protective custody and the riots and violence decreased significantly, despite and eighty-three percent rise in the population between the years of 1980 and 1985. New construction and renovation helped to fix what was lacking in the infrastructure of the institution in the previous decade. ${ }^{579}$ The High Security Center (“Supermax”) was opened in January of $1981 .{ }^{580}$ The Intake Service Center opened in July of $1982 .^{581}$ Middle management was strengthened, new policies and procedures were instituted, and officers were retrained. ${ }^{582}$ However, there were still some major setbacks. In November of 1982, voters rejected a bond issue that would help to finance some of the renovations of the older buildings, renovations deemed mandatory by judicial decision. ${ }^{583}$ This left Moran wondering how exactly he was going to meet the judicial mandates for improved conditions without being fined additional money, as yet again there was a fundamental conflict between what was

\footnotetext{
${ }^{578}$ Carroll, Lawful Order, 166.

${ }^{579}$ Carroll, Lawful Order, 158-159.

580 “State Finally Opens Supermax," The Providence Evening Bulletin, January 29, 1981, A1.

${ }^{581}$ Carroll, Lawful Order, 193.

${ }^{582}$ Carroll, Lawful Order, 158-159.

583 “ACI Bond Issue Rejected,” The Providence Journal, November 3, 1982, A12.
} 
"mandatory" and what the voters wished to fund. ${ }^{584}$ Finally in November of 1983, voters approved $\$ 4.9$ million to bring old Maximum security up to standards. ${ }^{585}$

The judiciary helped to bring in crucial programs that the ACI needed to truly be rehabilitative. This included medical and mental health services and drug treatment (both physical and addiction treatment). Also programs for job training and education were instituted. Much of this money was obtained through federal grants, like the Department of Education grant through the Title 1 program, the Law Enforcement Alliance of America, or the National Institute of Corrections. However, as the grants expired in the latter half of the 1980's, it became harder to develop the programs further. Other funding was gained from bonds that passed or through emergency appropriations. All of this funding, however, was necessary for conditions to change for everyone involved. Change would not have occurred nearly as quickly without the intervention of the court. ${ }^{586}$

Despite all of the major gains for the institution, the union found itself battling on various fronts, and at times found it difficult to survive. Judge Pettine had previously insinuated the judiciary's powers into contract negotiations between the employer and employee. In February of 1981, Pettine banned strikes (also in the form of sick-outs) and the union, in an attempt to keep afloat and not become defunct, had to bow to the orders from Pettine. ${ }^{587}$ In other time periods, this judicial interference in

\footnotetext{
584 “Moran Faces Task of ACI Revamp Without Help of RI Voters,” The Providence Journal, November 5, 1982, A3.

${ }^{585}$ Carroll, Lawful Order, 194.

${ }^{586}$ Carroll, Lawful Order, 195-206.

Overcrowding would also create a continuous pattern of "eroding the state's efforts to comply with court orders”. (Carroll, Lawful Order, 217)

587 "Guards call in sick job action,” The Providence Journal, February 19, 1981, A3.

"State of Emergency: Guards 'Sick,”' The Providence Evening Bulletin, February 19, 1981, A1.

“ACI Guards Bow to Judges Order to Work,” The Providence Journal, February 20, 1981, A3.
} 
labor would have been unthinkable. However, this age of conservatism provided support for Pettine’s anti-union actions.

However, the Brotherhood fought to stay united. One of the ways it maintained its sense of solidarity was through internal memorandums that kept union members abreast of ongoing arbitrations, committees, political discussions, and legislation. The function of these memos was to keep everyone on the same page and to educate members about the issues facing them. They also helped to elicit dialogue and keep members invested in their union.

While the newsletters covered a good deal of external events, they also spent a great deal of time on internal affairs, attempting to maintain the solidarity that a brotherhood should have. They instituted a stress management course. ${ }^{588}$ Also, the union put together a funeral detail to attend any funerals of former officers, present officers, and immediate family members of officers. ${ }^{589}$ This remains in effect today. They had holiday parties, sports leagues, and also competed in various competitions. ${ }^{590}$ In addition to this, they often publicized happy events, such as weddings and babies within their monthly newsletters. ${ }^{591}$ Often, they would recognize new correctional officers and welcome them to the Brotherhood. ${ }^{592}$

“Judge Stiffens Ban on Strikes By Guards at ACI,” The Providence Evening Bulletin, February 26, 1981, A14.

Ronald Brodeur, Interview with the author, March 7, 2011.

${ }^{588}$ Rhode Island Brotherhood of Correctional Officers, Newsletter Regarding Union Business, October 1985, Laurie collection.

${ }^{589}$ Ibid.

${ }^{590}$ Rhode Island Brotherhood of Correctional Officers, Memo Regarding Union Business, December 1984, Laurie collection.

${ }^{591}$ Ibid.

Rhode Island Brotherhood of Correctional Officers, Newsletter Regarding Union Business, April 1985, Laurie collection.

${ }^{592}$ Rhode Island Brotherhood of Correctional Officers, Memo Regarding Union Business, February 1985, Laurie collection. 
The Brotherhood held elections in November of 1981 and elected Ronald Brodeur as president, Michael Bonneau as first vice president, Ernest Battey as second vice president, Alan Silverman as secretary treasurer, Lee Sillivan as financial secretary, and Patricia O’Brien as recording secretary. ${ }^{593}$ In a memo to all RIBCO members, the major "pending" issues that the union was concerned with were: Seniority lists, super officers' contract, vacation "buy back", and uniforms. ${ }^{594}$ This suggests that the union was moving towards involvement in areas of professionalism (regarding unions) as well as looking to work on gaining more benefits. Seniority had become a clearly established principle for the union. The memorandum also solicited the involvement of new members and informed the newer officers that they were welcome to "drop a note or stop by the office in person” to discuss any issues they had or ways they wished to become involved. ${ }^{595}$ The memo urged all union members to: “PARTICIPATE and SUPPORT YOUR UNION!"596

The Brotherhood worked to establish committees to "effectively canvass" legislators on issues regarding health care benefits, sick time, and union representation. ${ }^{597}$ They also worked to make their views known on public radio shows and tried to counter public officials or administrator who took positions contrary to their views. One particularly inflammatory memo blasted John Moran for his remarks regarding the idea that "correctional officers are more concerned with working overtime than they are with their own safety”. Mr. Moran apparently called into the

\footnotetext{
${ }^{593}$ Rhode Island Brotherhood of Correctional Officers, Memo Regarding Union Business, November 27, 1981, Laurie collection.

${ }^{594}$ Ibid.

${ }^{595}$ Ibid.

${ }^{596}$ Ibid.

${ }^{597}$ Rhode Island Brotherhood of Correctional Officers, Memo Regarding Union Business, January 6, 1982, Laurie collection.
} 
WHJJ radio show which was hosting Ronald Brodeur (the president at the time) and Ken Rivard (grievance chair) to debate some of the issues. The memo sarcastically suggested: "Perhaps he should tour some of our facilities when the inmate population is not locked up.” It also stated: "Is Moran concerned with the safety of our staff here at the A.C.I? After his remarks on this program, I say emphatically, No way!!”598 After this particularly aggressive encounter, the radio programs were left clamoring for more and the union made arrangements for two other shows (one on the radio and one television program). ${ }^{599}$

Overcrowding was also a major issue for officers to battle as the War on Drugs was fully underway, and prison populations skyrocketed. ${ }^{600}$ Meanwhile, the administration consistently found themselves speaking to the press, asking the public to provide them with sufficient funds to meet their increasing list of demands. ${ }^{601}$ The administration felt that it would be best to double up inmates in their cells to fix the overcrowding and proposed laying off about fifty members of the staff in order to remedy their budget dilemma. ${ }^{602}$ Ronald Brodeur, was president of the Brotherhood at this time of overcrowding and a tough economy, which affected the budget of the prisons. ${ }^{603}$ He noted how the union defended against staff cutbacks in testifying before committees and at hearings. Management, trying to meet the economic and administrative demands of the prison, "had, in some occasions, not had the safety of

\footnotetext{
598 Ibid.

${ }^{599}$ Ibid.

600 “ACI Overcrowded Despite Supermax,”The Providence Evening Bulletin, March 3, 1981, A1. "Mandatory Jailing and Prison Overcrowding,” The Providence Journal, March 17, 1981, A22.

601 “New Warden’s Worries: 'Budget, Budget, Budget,” The Providence Evening Bulletin, November 6, 1981, A3.

602 “ACI Doubling Up Inmates in Cells, May Lay Off 50 Members of Staff,” The Providence Journal, October 1, 1981, A1.

${ }^{603}$ Ronald Brodeur, Interview with the author, March 17, 2011.
} 
the officers as their priority", ${ }^{604}$ The union protected the staff "to the best of [their] ability and fought to keep critical positions. ${ }^{605}$ The age of conservatism was one that affected the officers on multiple fronts: with regard to an unfriendly attitude toward labor in general as well as a drastic rise in the prison population.

In the contract negotiations of 1982-1983, the state negotiators worked to try to reduce seniority rights. Attorney for the Brotherhood, Gerard Cobleigh views seniority rights as the "backbone" for a lot of the decisions made by the union. ${ }^{606}$ Every rule for the union regarding posts, shifts, vacation, and days off was and still is based on seniority rights. ${ }^{607}$ For eighteen months, contract negotiations hit an impasse. ${ }^{608}$ The union called a meeting with the governor to discuss several issues of concern regarding how state money was being spent and why the state allowed its chief negotiator to be absent from negotiations for two months, on vacation. ${ }^{609}$ They hoped to bring his representatives back to the table to "engage in 'good faith bargaining., ",610 A memo reiterated the stance of the union in stating: "STATE EMPLOYEES ARE NOT RESPONSIBLE FOR THE STATE'S FINANCIAL WOES."611

Upon meeting with the RIBCO officials, the governor reiterated the mantra of the times. He "painted a very bleak picture for state employees" and stated that there

\footnotetext{
604 Ibid.

605 Ibid.

${ }^{606}$ Gerard Cobleigh, interview with the author, October 29, 2011.

${ }^{607}$ Ibid.

${ }^{608}$ Carroll, Lawful Order, 167.

${ }^{609}$ Rhode Island Brotherhood of Correctional Officers, Memo Regarding Union Business, March 22, 1983, Laurie collection.

${ }^{610}$ Ibid.

${ }^{611}$ Ibid.
} 
were "painful" times ahead. ${ }^{612}$ He continued to blame the legislature and argue that his hands were often tied. However, he promised to continue meeting with union officials in an attempt to solve their problems. ${ }^{613}$

In March of 1983, elections for RIBCO were held again. The executive board stayed relatively the same: Ronald Brodeur as president, Michael Bonneau as first vice president, Ernest Battey as second vice president, Alan Silverman as secretary treasuer, Lee Sillivan as financial secretary, and Ronald Quaglieri as recording secretary (as Patricia O’Brien vacated her previous position) ${ }^{614}$ This signifies a high degree of confidence and satisfaction with the union among the rank and file.

The later part of 1983 led to a couple of job actions that were quickly squashed. Ronald Broule was reassigned to medium security as deputy warden. Many were against this and in August of 1983, the officers engaged in a sick-out in protest of his policies. John Moran got a court order to force them back to work. ${ }^{615}$ Two months later, there was another incident in which a shift of officers who were at a union meeting (regarding contract negotiations), were a half an hour late to work. The administration then charged that they were in civil contempt for violating the 1981 injunction on job actions placed on them by Judge Pettine. This was a case where the state found that the union was in contempt. ${ }^{616}$ These two incidents effectively worked to persuade the union to not engage in any more job actions. Again, in this age of

\footnotetext{
${ }^{612}$ Rhode Island Brotherhood of Correctional Officers, Memo Regarding Union Business, April 4, 1983, Laurie collection.

${ }^{613}$ Ibid.

${ }^{614}$ Rhode Island Brotherhood of Correctional Officers, Newsletter Regarding Union Business, March 14, 1983, Laurie collection.

${ }^{615}$ Carroll, Lawful Order, 168.

“Judge Grande Orders Guards to End Sickout,” The Providence Journal, August 30, 1983, A1.

${ }^{616}$ Carroll, Lawful Order,168.

“ACI Seeks to Penalize Late Guards,” The Providence Journal, November 10, 1983, A3.

"Prison Guards Found in Contempt,” The Providence Journal, December 17, 1983, A5.
} 
conservatism, the public fully supported Moran and the courts in cracking down on any job actions by public sector unions.

In December of 1983, the union and the state worked out a new contract. ${ }^{617}$ Although fighting vociferously against the implementation of a new sick leave bill, relations with administrators seemed to be in a cooling down period ${ }^{618}$ However, the officers now had to refocus as tensions among the inmate population soared with the increasing number of inmates. ${ }^{619}$ The year of 1984 kicked off with another significant disturbance in which one hundred inmates rioted. ${ }^{620}$ Also, fires were running rampant as inmates continuously (from the early 1980s), would set their mattresses on fire in protest. ${ }^{621}$ This was until fireproof mattresses were brought into the facilities. ${ }^{622}$ After this, inmates began setting fires to the industrial shops. ${ }^{623}$ It was clear that the conditions, while better, were not nearly up to par in regards to safety.

The sick leave bill, intended to crackdown on abuse of sick leave, did pass through the Rhode Island legislature but did not work out in practice. One RIBCO newsletter explained the reasons why the sick bill did not work, as the union had predicted. In a state of frustration, they exclaimed: “... Correctional officers are still getting sick, and correctional officers are still being assaulted by inmates, and don't forget those nasty little buggers who take their vacations." ${ }^{\text {624 }}$ This sums up a great

\footnotetext{
617 “Guards and State Strike Tentative Accord,” The Providence Journal, December 22, 1983, B10.

${ }^{618}$ Rhode Island Brotherhood of Correctional Officers, Memo Regarding Union Business, February 3, 1984, Laurie collection.

619 “ACI's Population is Highest Ever,” The Providence Journal, February 14, 1984, A3.

620620 “100 Join Melee at ACI: 4 Are Hurt,” The Providence Journal, February 20, 1984, A1.

${ }^{621}$ William Laurie, Interview with the author, August 3, 2011.

622 Ibid.

623 “Blazes Damages Shop Building in Maximum Security Unit,” The Providence Journal, April 4, 1985, D4.

${ }^{624}$ Rhode Island Brotherhood of Correctional Officers, Memo Regarding Union Business, June 1984, Laurie collection.
} 
deal of frustration that these workers felt at being caught in the middle of conservative legislation and their working conditions.

The officers continued to place personal profiles in the paper. One particularly moving personal profile was written on David Thornton, an officer who returned to the job, after having his throat slashed. ${ }^{625}$ While these personal profiles were less frequent than in the 1970's, when there were less press restrictions, they still served to make the public aware of the dangers the officers faced and the fact that the facilities were still not safe.

Publicized disturbances and personal profiles in the press in 1985 did help the officers in contract negotiations. Negotiations were "easier" during this time period, than in future years, because the state was willing to pay the officers to keep them working and on the job. ${ }^{626}$ As inmates continued to protest their conditions, officers had to continue to remain strong as the state struggled to work out the reforms at a snail’s pace. ${ }^{627}$ In 1985 , officers received a five and a half percent pay increase. ${ }^{628}$ Officers also won the battle regarding compensation for working through their scheduled break times. ${ }^{629}$

In 1987, RIBCO elected a slate of officers. John Sabalewski became president (succeeding Ronald Brodeur). In addition to this, was James Dardeen who was

625 “Tough Stuff,: Back on the Job After Facing the Worst,” The Providence Journal, April 14, 1985, E1.

${ }^{626}$ Kenneth Rivard, Interview with the author, March 29, 2011.

627 “ACI Orders Lockup After 90 Minute Protest," The Providence Journal, September 27, 1985, A1. "180 Prisoners Have Standoff With Guards: Officials Say Cause Was Inmate Fight," The Providence Evening Bulletin, September 27, 1985, C6.

"Inmates Stand Off Police for 2 and a half Hours Before Giving In,” The Providence Journal, October 1, 1985, A1.

628 “ACI Guards Will Get 5.5\% Raises in New Contract, Moran Says,” The Providence Journal, November 16, 1985.

629 "Guards Win Compensation for Work on Break Time,” The Providence Evening Bulletin, November 21, 1985, A22. 
elected first vice president, Steven McCaffrey as second vice president, Alan Silverman as treasurer, Gail Kuras as financial secretary, and Richard Loud as recording secretary. ${ }^{630}$

1987 and 1988 were years in which RIBCO took a more public stand on some of the major issues facing the ACI. They came out against the privatization of the industries within the ACI (an issue that would haunt the union through the 1990's). ${ }^{631}$ It was felt that privatization harmed the security of the institution because many of the activities and vehicles brought in by private companies were not under the control of the officers and were, thus, subject to a greater possibility of contraband. ${ }^{632}$

In July 1988, officers took a strong public stance regarding being called to work overtime over the July $4^{\text {th }}$ weekend, saying that this breeched their contract (especially since the officers were still occasionally blamed for abusing overtime, as consistent with public sentiment during this age of conservatism). ${ }^{633}$ Also in July, the union cast a no confidence vote regarding new assistant director Don Ventetuolo. ${ }^{634}$ The officers felt that his approach was increasing resentment which would lead to more grievances being filed. They called on the governor to appoint an independent mediator to avoid arbitrations. The union felt that there were not a sufficient number of captains or lieutenants. They also felt that the seniority system was hurting staff development. The officers would not agree to in-service training without being paid for it. Also, Ventetuolo was promoting younger officers in a manner that violated the

630 "Prison Guards Elect Union Slate at ACI,” The Providence Journal, December 3, 1987, A28.

631 “ACLU Opposes 'Privatization' of State Prisons, Corrections Officers Union Also Questions Option,” The Providence Journal, January 1, 1988, A3.

${ }^{632}$ Ronald Brodeur, Interview with the author, March 17, 2011.

633 "Union Says Prison Broke Contract, Forced Guards to Work Overtime Over $4^{\text {th }}$ of July Weekend," The Providence Journal, July 7, 1988,B18.

${ }^{634}$ Carroll, Lawful Order, 230. 
collective bargaining agreement the officers had with the state and also violated civil service regulations. ${ }^{635}$ More importantly, the union began to protest the conditions caused by the overcrowding in the public sphere, bringing more public attention to their working conditions and the compulsory overtime. The union organized a demonstration in front of the State House, involving an impressive two hundred and fifty officers, to bring public attention to their grievances, without requiring job action. ${ }^{636}$

In 1989, RIBCO (and the ACLU) came out against the proposition of a home confinement bill. ${ }^{637}$ They felt this was not a proper way to deal with the skyrocketing prison population problem and would not lead to proper rehabilitation. Judge Pettine continued to impose fines on the state, whenever they went over his established quotas. ${ }^{638}$ It was ordered that an Emergency Overcrowding Relief Fund be established, which provided the state with $\$ 164,250$. Yet this merely offset the increases over the past couple of years and did little to stem the tide of increasing population. ${ }^{639}$ However, despite these clear problems, Judge Pettine, in May of 1989, found that he had to bow out of the prisoners' rights case, at the age of seventy seven. ${ }^{640}$

While Judge Pettine brought about many reforms for the prison system of Rhode Island, some of his more hardline tactics held back the flow of progress. As the

\footnotetext{
${ }^{635}$ Carroll, Lawful Order, 230.

636 “ACI Guards Protest Over Crowding, Cite Mismanagement,” The Providence Journal, September 16, 1988, A3. "250 Guards Demonstrate at State House to Protest ACI Working Conditions," The Providence Journal, September 21, 1988, G1.

637 “ACLU, Guards Criticize Home Confinement Bill,” The Providence Journal, June 20, 1989, A6.

${ }^{638}$ Carroll, Lawful Order, 243.

${ }^{639}$ Carroll, Lawful Order, 244.

${ }^{640}$ Judy Rakowsky, "With a Heavy Heart, Judge Pettine Leaves ACI, Brown Cases," The Providence Journal, May 3, 1989, A1.
} 
prison system kept growing and expanding, it was unfair to expect the Department of Corrections to keep up with the growth without providing an economic means of making these expectations a reality. The burden of the unrealistic goals would fall on the officers, and thus a whole new cycle of frustration would begin. With new judicial leadership also came a refreshing of relations between the judiciary, the Department of Corrections, and the officer's union.

Also in 1989, the union received a new contract. While negotiations were not nearly as intense as previous years, the major sticking point during these negotiations were questions regarding as to whether the administration had right to post officers throughout the ACI as they wished. Officers contended that this infringed on the seniority rights that allowed workers with a greater number of years in the system to choose where they work. ${ }^{641}$ In the end, the state and the union negotiated a two year agreement. This agreement included a compromise with regard to the number of consecutive eight-hour shifts the officers could work; they were granted five in the first year of the contract and four shifts in the second year of the contract. This helped with regard to cutting overtime and the kept the officers from becoming exhausted on the job. Officers received a 9.4\% wage increase, an increase in workers' compensation benefits, and a reduction in how long guards had to wait for longevity pay increases. Officers now had the right to have electronic belt alarms (tasers) for dangerous situations, which could also signal the guard's position when activated. These negotiations went well, when compared to other state workers, and the rank and file ratified the agreement (by a four to one ratio) despite some misgivings. Many officers

${ }^{641}$ Tom Mooney, “ACI Guards, State Agree on a Contract,” The Providence Journal, October 18, 1989, A1. 
were still not content regarding "state's unsympathetic attitude toward working conditions at the ACI. ${ }^{642}$

In 1988 and 1989, Rhode Island surpassed all other states in the percentage of population growth within the prison system and this took a serious toll on the reforms that were put into place and the working atmosphere of the officers. ${ }^{643}$ Drug offenses were increasingly treated as felonies, which meant that penalties were harsher and ended in more incarcerations. ${ }^{644}$ Prisons that were operated by a state were harder hit than those that operated in a county system due to the extreme demands placed on states with a central facility. These demands could not be spread out among facilities. ${ }^{645}$ While a large portion of this overcrowding resulted from the War on Drugs, the mental health and substance abuse programs available were far outstripped by the increasing population. ${ }^{646}$ In an interesting paradox, Judge Pettine established a precedence in which fines could be used to reduce crowding within the prisons. ${ }^{647}$ Judges were applying stricter sentences were placing prisoners into incarceration, while other members of the judiciary fine the prisons for overcrowding and not being able to keep pace. The ACI depended on money to be flowing in from the legislature and the federal government, yet was placed at fault when the sentencing far outpaced the resources available. Both administration and officers were placed in a bind. While they both realized that they were fighting the same battle, union president at that time, Ron Brodeur, explains that there "should have been a partnership between

\footnotetext{
${ }^{642}$ Tom Mooney, "Prison Guards Ratify 2-year Deal With State; Pact Fails to Please Everybody, but Union Chief Claims Victory,” The Providence Journal, October 25, 1989, A3.

${ }^{643}$ Carroll, Lawful Order, 213.

${ }^{644}$ Carroll, Lawful Order, 216.

${ }^{645}$ Carroll, Lawful Order, 216.

${ }^{646}$ Carroll, Lawful Order,225.

647 "Pettine Weights Fines as Means to Reduce Crowding at Prison,” The Providence Journal, May 24, 1987, A3.
} 
management and the union," and yet, this never came about. ${ }^{648}$ At the same time, within the ACI in particular, many of those who held middle management positions resigned or were replaced. This did not help the system progress in the way of continuity. ${ }^{649}$

However, the Brotherhood maintained a sense of continuity through strong leadership. Throughout the 1980's, the union leadership did not change much. Ronald Brodeur held the spot of president for seven years and, even after his presidency, still maintained a strong presence as second vice president (after a small break). ${ }^{650}$ Attorney for the union, Gerard Cobleigh, explains that he finds the consistency in "strong and effective" union leadership to be crucial to the growth and development of the union. ${ }^{651}$ He explains that Ken Rivard has been extremely essential to this strong leadership, having been involved in the union for thirty seven years. He believes that Mr. Rivard and people like Mr. Rivard are "helpful in advancing the interests of the organization" because they "know all the history," and, in Mr. Rivard's case, are “involved in every arbitration and every negotiation and every court case., ${ }^{652}$

Throughout this age of conservatism, it can be seen that RIBCO not only survived, but actually became stronger. Not only did it manage a pattern of consistently improved contract negotiations and contracts, but it also managed to maintain the solidarity that it had started with in 1970. This was no minor

\footnotetext{
${ }^{648}$ Ronald Brodeur, interview with the author, March 17, 2011.

${ }^{649}$ Carroll, Lawful Order, 227.

${ }^{650}$ Ronald Brodeur, Interview with the author, March 17, 2011.

“Ronald Brodeur, Again Leader of ACI Guards' Union,” The Providence Journal, December 4, 1985, A14.

${ }^{651}$ Gerard Cobleigh, Interview with the author, October 29, 2011.

${ }^{652}$ Ibid.
} 
achievement, as public sector unions had the worst conditions. Their working conditions were not being funded by the American public and they were attacked for their unionization efforts.

The Brotherhood managed to maintain a public presence even though there were stringent guidelines regarding interactions with the press. They presented themselves in such a way to illicit sympathy from a public who, despite the conservative conditions, became aware that funding for the prison needed to increase for the situation to change for the better. Also, they developed a working relationship with the administration that was much more positive than it had been in the 1970s, and was much less confrontational. Officers were presented as valued workers, and now the administrators and the press treated them as such.

RIBCO had grown considerably in size. They now represented seven hundred and fifty officers and nearly eighty other state workers. ${ }^{653}$ In the beginning of the 1970s, they represented only one hundred and sixteen workers. ${ }^{654}$ This was startling considering the great decrease in union membership that was harming the labor movement in every sector. Much of this was due to the great increase in funding brought in by bonds and the judiciary. However, it was RIBCO that made it clear, in defending officer safety, that more officers were needed to maintain security within the facilities. This stance on officer safety and the unity of the Brotherhood had never quelled in the wake of conservatism. This was part of the genius of organizing as an independent union.

\footnotetext{
653 Tom Mooney, "Prison Guards Ratify 2-year Deal With State; Pact Fails to Please Everybody, but Union Chief Claims Victory,” The Providence Journal, October 25, 1989, A3.

654 “ACI Guards Eye New Labor Union,” The Providence Journal Bulletin, December 18, 1970, 29.
} 


\section{The 1990's: Regaining Control}

With all of the pieces in place, the administration and the officers were ready to unite to fundamentally change the prison system of Rhode Island forever. The 1990's were a time period where there was a realization of the goals of the union. Safety was brought to the facilities and maximum was secured once in for all, following a riot in 1991. They had safer, more dignified conditions. The officers were paid better with benefits. They had clearer directives, and an administration that valued them. The officers were treated as professionals by the administration, Department of Corrections, the legislature, the press, and the public. The job description changed from being "guards” to being “correctional officers”. They established a pre-service training system and pay incentives for those continuing their education. There was a clear rehabilitative program in place which helped to solve some of the issues that the officers were dealing with previously, in terms of drug use and violence. The union became a true brotherhood, made up of officers who protect one another and value one another. Work was no longer a prison for the officers.

There were two goals of the union during the 1990's: the first was to "take back maximum security” and the second was to achieve binding arbitration. The priority of the officers was to place control of the facilities back into the hands of the officers and management. Only in taking control of maximum security, would the goals of the 1970's be truly realized. The officers needed to ensure that they would be safer and not always in a constant state of turmoil. This was made possible by an increase in the amount of available resources, shifts in policy, and one final riot which ended the showdown between the officers and the inmates. 
Retired captain Ronald Brodeur credits the shift in policy with a change in management. Management began to shift its position with the hiring of George Vose as director of the ACI and Joe Pont, and the promotions of Walt Whitman and Tommy Partridge. They made it their mission to tighten up security at maximum, through policy and through various decisions made about discipline boards. ${ }^{655}$

Most of the issues regarding the frustrations of the officers remained the same. Most officers were concerned with budget problems, staff shortages, post cuts, wage reductions, pay deferrals, and layoffs. ${ }^{656}$ Members were concerned that they were working shifts alone, in potentially dangerous situations. In the coming contract negotiations, the union leadership promised to address issues of the "health, safety, and welfare” of their officers. ${ }^{657}$

It turns out that they had quite a reason to be fearful. On September 30, 1991, there was a riot involving three hundred inmates that went on for five hours. They were protesting the recent change in the leadership at Maximum security. ${ }^{658}$ Officers recognized it as "a turning point for maximum security”. ${ }^{659}$ It seemed as though inmates finally realized they they were "no longer going to be a part of the management of maximum security”. ${ }^{660}$ Management appeared to be on the side of the officers, implementing many of the changes suggested by officers over the past two decades. ${ }^{661}$

\footnotetext{
${ }^{655}$ Ron Brodeur, Interview with the author, March 17, 2011.

${ }^{656}$ Rhode Island Brotherhood of Correctional Officers, Newsletter Regarding Union Business, August 1991.

${ }^{657}$ Ibid.

${ }^{658}$ Tom Mooney, “300 inmates in 5-hour standoff with ACI guards, state troopers,” The Providence Journal, October 1, 1991, A1.

${ }^{659}$ Rhode Island Brotherhood of Correctional Officers, The Communicator, October 1991.

${ }^{660}$ Ibid.

${ }^{661}$ Ibid.
} 
Mr. Ronald Brodeur has a unique point of view as he was the only officer to be present for the start of the riot on September 30, 1991. As day shift commander, he was in charge of the other officers on duty. The officers and management had heard rumors about a possible riot and it became clear that it was going to occur when the inmates were in the yard and refused to go back to their cells. He says that the inmates were "pretty much determined to take it to another level." He told all of his officers to go back inside, to keep them safe. He then tried to reason with the inmates, through a runner. He asked them to go back to their cells and he would have one or two representatives to talk to management, but they were not willing to compromise. He said to them: “It's up to you guys. You're gonna end up going in one way or the other. ${ }^{, 662}$ Mr. Brodeur paints the picture:

"So it actually started around me. And all hell broke loose, ya know. They uh, as I said they destroyed the plate shop. They pretty much destroyed that industrial building. Um, they set fire, they were throwing rocks, they had weapons, uh. At one point the tag team went in through the crib and confronted them. ${ }^{, 663}[\mathrm{sic}]$

The confrontation did not result in any physical violence or force, it was an intimidation tactic by the officers and state police. In the meantime, Mr. Brodeur went inside and was told to report to the reception area and then was told to report back inside. An added complication that needed to be dealt with was the fact that there were other inmates who were not in the same area and were not part of the riot. These inmates needed to be taken out to protect them and to keep them from joining in. Mr.

\footnotetext{
${ }^{662}$ Ibid.

${ }^{663}$ Ibid.
} 
Brodeur was put in charge of this task. He was given several buses and then had to find a way to get these inmates over to the intake center. He describes it as such:

"But I was able to uh get my way through a series of gates on the outside and I actually had to break a window to get into the control center. Once I got in, we got that building evacuated, transferred all the inmates over to intake., ${ }^{, 64}[\mathrm{sic}]$ Clearly, the atmosphere was chaotic. Eventually the riot ended when the inmates got tired and realized that they were not accomplishing anything. But Mr. Brodeur, just like Mr. Rivard, views this riot as a turning point. The officers began to show the inmates that they were running the prison. After the riot, the four hundred and forty four inmates were in lockdown until all weapons had been confiscated. ${ }^{665}$ Many were homemade and, often times, were hidden in the blocks of their cells. This meant that each cell needed to be individually searched. It became clear to the inmates that conditions had shifted. He explains:

"And that was a major, that was a major thing in changing the mindset from the inmates run things to now the officers run it. And we did you know...” “... And the inmates knew. The jig is up you know. I guess they [the officers] are gonna run it.”[sic] 666

The riot elicited the sympathy of the public and management. ${ }^{667}$ The riot helped to open up the labor discussion and make change possible. The public and management knew what the officers were going through and paid them what they wanted to keep

\footnotetext{
${ }^{664}$ Ibid.

${ }^{665}$ Peter E. Howard, "Damage assessed in ACI Riot Aftermath: Lockdown continues until all weapons are confiscated,” The Providence Journal, City Final edition, October 5, 1991, Sec A 3.

${ }^{666}$ Ron Brodeur, interview with the author, March 17, 2011.

667 “Who’s in Charge,” The Providence Journal, Metro-West edition, October 4, 1991, Sec A 14 (editorials).
} 
them around. ${ }^{668}$ It also changed the working environment for the officers within the prison. Groups of prisoners involved in the riot were separated and some were transferred out of Rhode Island, in a divide and conquer tactic. ${ }^{669}$ The public reaction and the change in administrative policy demonstrated to the inmates that they were no longer in control of the prison. A new era had begun. An article in the Providence Journal titled “ACI riot backfired, inmates discover” captures the mood, one in which a strict new era was applauded by all. The article states:

“'The officers have been given their authority back,” said one maximum security guard. 'Morale is two thousand percent better than it was. Officers are working together, doing their jobs. The harmony of the whole place is unbelievable.’”, 670

As Ron Brodeur illustrates it, twenty years later: “And things just happened for the better, you know. After that riot we took, we really took back control.” 671

Not only did the officers take back control of their most challenging work environment, but they did it with the blessing and the assistance of their administrators. The riot came about as a last attempt on the part of the inmates to persuade the administration to falter in their enforcement of the correctional officers requests. Now the administration and the workers developed a constructive relationship by which they could achieve many great things.

\footnotetext{
${ }^{668}$ Ken Rivard interview with the author, March 10, 2011.

${ }^{669}$ Laura Meade, "Prisoners at ACI transferred out of R.I.," The Providence Journal, City Final Edition, October 6, 1991, Sec B 1.

${ }^{670}$ Tom Mooney, “ACI Riot backfired, inmates discover,” The Providence Journal, City Final edition, November 2, 1991, Sec A 3.

${ }^{671}$ Ron Brodeur, personal interview by author, held in the RIBCO offices located in the Maximum security facility of the Adult Correctional Institution, March 17, 2011.
} 
After this, the most important change for the union was in achieving binding arbitration. Attorney for the union, Gerard Cobleigh, believes that this has given a great degree of leverage to the union regarding contract negotiations. ${ }^{672}$ Typically, public sector unions have not fared well without binding arbitration. Unions require money and resources to bring cases to arbitration and, if the arbitration can later be ignored by the state, the money and the resources would have been wasted. The major player in achieving binding arbitration was Richard Ferruccio, who was president of RIBCO ${ }^{673}$ In defending binding arbitration, Ferruccio stated:

"Our members have lagged far behind other state employees in other comparable classifications, despite the fact that we work in one of the most challenging and dangerous environments in either the public or private service. ${ }^{674}$

In addition to this, binding arbitration does help to ensure that negotiations are enacted on a "good faith" basis and this helps to maintain positive relations between employer and employee.

Overall the 1990's (with the exception of the riot of 1991) were notable in their lack of turmoil and lack of tumultuous events. The union had established itself within the state as a necessary force to be reckoned with. The skills of the worker had become valued in the public sphere. The increased degree of communication between the union, the administration, and the public has worked to provide funding and proper

\footnotetext{
${ }^{672}$ Gerard Cobleigh, interview with the author, October 29, 2011.

${ }^{673}$ Ibid.

Bruce Landis, “Prison-guard contract bill vetoed,” The Providence Journal, June 18, 2004, B6.

Scott McKay, "Judge says arbitration is proper method," The Providence Journal, December 8, 2006, B1.

${ }^{674}$ Scott McKay, “Judge says arbitration is proper method,” The Providence Journal, December 8, 2006, B1.
} 
remedy to the many problems facing the ACI in the state of Rhode Island. These three have now achieved a harmony and have worked together to make the taking back of maximum security and the workplace possible. 


\section{CHAPTER 6}

\section{CONCLUSION}

In the works of Kenneth Rivard, the officers will "never let it go back to the way it was”. This is certainly true. This author has taken a tour of the maximum and intake facilities and both appeared to be safe, orderly, and part of a well-oiled machine. Every once and awhile, in the maximum security facility, there are still some remnants of the past, eerie reminders to the officers to never take the security for granted.

The Brotherhood has encompassed the families who sent their loved ones into literal battle every single day, and they worked to also protect these families. This union is unique in that it maintained its militant stance for such a long period of time. Most labor unions are able to carry this off for a short period and then obtain some level of success or fail. If labor activity is carried on for an extended period of time, activists become weary. ${ }^{675}$ This was not the case with RIBCO.

In the court system, which is where the battlefield for union action was transferred to over time, the union required funds to successfully defend their cases. While this is a major strength of larger labor organizations, RIBCO also had the strengths of public sympathy and press exposure. They could afford to remain independently organized and benefited greatly from it because their work environment

\footnotetext{
${ }^{675}$ As an example: The Homestead Strike of 1892 (in which workers battled the Pinkerton agents) (The battles only lasted a few months and ended in defeat.), The Western Federation of Miners in Paterson New Jersey in 1913 (in which local authorities acted in a harsh manner and ended in defeat), or the concessionary actions of the United Auto Workers in the wake of the riots in Detroit in the late 1960's and early 1970's and the purging of more militant factions in the Motown factories. Who Built America, The American Social History Project, Worth Publishers, New York, NY, 2000, 112-114, 229-230, 670.
} 
was so unique. Raising funds would require a good deal of effort to keep the union afloat and successful. Much of this fundraising now takes place at political gatherings, events, and inaugurals, where the politicians could be found. The hard work of union board members, particularly with regard to lobbying and fundraising, has been crucial to the success of the union both in the earlier years and in the present time. ${ }^{676}$

RIBCO has achieved its goals of the early 1970's regarding officer safety, wage increases, and dignity. They have established their workers as a needed or valued element of society. This union, in organizing independently, has achieved its previous goals and has gone far beyond what was originally perceived as possible and what was impossible for many other unions of its time.

In addition to this being an informative case study regarding public sector unions, this examines a group of workers that are not always visible to the public: correctional officers. This union formed out of necessity, as its workers were facing danger on a daily basis. Part of the success of this union was due to the great efforts made by the union leadership to make themselves easily accessible and more visible to the general public.

The history of the Rhode Island Brotherhood of Correctional Officers combines the fields of post-war labor, unionism within the field of corrections, as well as unionism within the public sector. This union found itself within a peculiar set of circumstances as its workers were part of a major growth industry (as the number of incarcerations skyrocketed due to the War on Drugs). At the same time the union had to battle the public's unwillingness to spend money to improve their conditions, during an age of fiscal conservatism. This union faced the tests of the latter portion of

\footnotetext{
${ }^{676}$ Ronald Brodeur, Interview with the author, March 17, 2011.
} 
the 1970's and the age of conservatism of the 1980's, and became stronger and more united while other unions of the same time period failed. It was able to achieve its goals due to consistent and strong leadership as well as the independent nature of its organization.

This union formed as an independent union, in response to a lack of proper representation and due to an urgent need to protect its workers from the dangers of daily life within the prison at this time. The independent nature of the union allowed the union leadership to respond directly to matters that required urgent attention, thus making the union a powerhouse that the administration and politicians both needed to contend with when making decisions that affected workers. Over time, a better working relationship between the middle management and the union evolved and this, combined with a great degree of communication with the public, made RIBCO one of the most powerful unions in the state of Rhode Island today, representing nearly 1,300 workers. ${ }^{677}$

This labor history has much to offer to the present-day discussion regarding public sector unions. Public sector unions always pay the price during tough economic times. Public sector employees currently find their candle burning at both ends: they are overworked, underpaid, and always under attack. While RIBCO certainly is a unique case, under a unique set of circumstances, is an example that for the rest of the labor movement to follow in its tenacity, innovativeness, and solidarity.

This union struggled with many of the same problems that public sector unions are facing at the present time. This too is an age of economic hardship. A resurgence

\footnotetext{
${ }^{677}$ Rhode Island Brotherhood of Correctional Officers, “About Us,” http://www.ribrotherhood.com/aboutus.php (accessed April 11, 2012).
} 
in conservative ideals are leading various factions to work against the labor sector, leaving many workers and unions questioning how to best deal with their own particular set of circumstances. This case study holds many implications for present day studies which examine the current direction of the labor movement. RIBCO is an example of a successful union organization that succeeded at a time when other unions could not. This case study proves that independent organizations, outside of the mainstream union bureaucracy, can find a good measure of success and can thrive in a climate that is unfriendly to labor. 


\section{BIBLIOGRAPHY}

\section{Primary Sources}

\section{$\underline{\text { Interviews }}$}

Brodeur, Ronald. Interview with the author. March 17, 2011.

Cobleigh, Gerard. Interview with the author. October 29, 2011.

Laurie, William. Interview with the author. August 3, 2011.

Rivard, Kenneth. Phone interview with the author. March 6, 2012.

Rivard, Kenneth. Interview with the author. March 29, 2011.

Archival

Ken Rivard to Richard C. Dujardin. August 2, 2010. Personal collection of Ken Rivard. Rhode Island Brotherhood of Correctional Officers.

Photos from the Personal Collection of William Laurie. Rhode Island Brotherhood of Correctional Officers.

Photos from the Personal Collection of Ronald Brodeur. Rhode Island Brotherhood of Correctional Officers.

Rhode Island Brotherhood of Correctional Officers. The Communicator. October 1991. Laurie collection.

Rhode Island Brotherhood of Correctional Officers. Memo Regarding Union Business. November 27, 1981. Laurie collection.

Rhode Island Brotherhood of Correctional Officers. Memo Regarding Union Business. January 6, 1982. Laurie collection.

Rhode Island Brotherhood of Correctional Officers. Memo Regarding Union Business. March 22, 1983. Laurie collection.

Rhode Island Brotherhood of Correctional Officers. Memo Regarding Union Business. April 4, 1983. Laurie collection.

Rhode Island Brotherhood of Correctional Officers. Memo Regarding Union Business. February 3, 1984. Laurie collection.

Rhode Island Brotherhood of Correctional Officers. Memo Regarding Union Business. June 1984. Laurie collection. 
Rhode Island Brotherhood of Correctional Officers. Memo Regarding Union Business. December 1984. Laurie collection.

Rhode Island Brotherhood of Correctional Officers. Memo Regarding Union Business. February 1985. Laurie collection.

Rhode Island Brotherhood of Correctional Officers. Newsletter Regarding Union Business. March 14, 1983. Laurie collection

Rhode Island Brotherhood of Correctional Officers. Newsletter Regarding Union Business. April 1985. Laurie collection.

Rhode Island Brotherhood of Correctional Officers. Newsletter Regarding Union Business. October 1985. Laurie collection.

Newspaper

“2 ACI Inmates Escape Detail.” The Providence Journal Bulletin. March 14, 1970, 2.

“2 ACI Prisoners Flee Work Detail. $3^{\text {rd }}$ Recaptured.” The Providence Journal. December 29, 1972, 4.

“2 ACI Prisoners Sought After They Disappear.” The Providence Journal. June 2, 1970, 13.

“3 Guards Injured in Fight at ACI.” The Providence Evening Bulletin. August 15, 1974, A1.

“3 Inmates Tell About 'Garbage War.” The Providence Evening Bulletin. August 1, 1980, A5.

“3 Inmates Tell of Beatings By Guards. Troopers at ACI.” The Providence Evening Bulletin. August 8, 1973, 33.

“3 Killers Hunted in Break at ACI.” The Providence Journal. September 21, 1972, 1.

“4 Are Injured In Three-hour Revolt at ACI.” The Providence Journal. August 27, 1977, A1.

“4 Guards Hurt. Fires Set in ACI Melee.” The Providence Evening Bulletin. April 2, 1973, 1.

“ $4^{\text {th }}$ Meeting Is Set About ACI Situation.” The Providence Evening Bulletin. January 19, 1972, 35. 
“11 Prisoners Moved to Avert ACI Riot.” The Providence Evening Bulletin. November 19, 1971, 1.

“\$13.9 Million Bond Sought for ACI.” The Providence Evening Bulletin. October 27, 1976, A2.

“14 Complete Corrections Course.” The Providence Journal. August 12, 1972, 11.

“14 ACI Guards Taking Course in Corrections.” The Providence Journal. July 12, 1972, 13.

"16 Inmates. ACI Guard Indicted in Escape of 4." The Providence Evening Bulletin. February 27, 1973. 1.

“50 Inmates in Brief Brawl in Dining Area.” The Providence Evening Journal. December 6. 1973, 1.

“100 Join Melee at ACI: 4 Are Hurt.” The Providence Journal. February 20, 1984, A1.

“180 Prisoners Have Standoff With Guards: Officials Say Cause Was Inmate Fight.” The Providence Evening Bulletin. September 27, 1985, C6.

“250 Guards Demonstrate at State House to Protest ACI Working Conditions.” The Providence Journal. September 21, 1988, G1.

“A New Warden.” The Providence Evening Bulletin. May 14, 1973, 26.

“ACI Accord Reached; Rehiring of Guards Set.” The Providence Evening Bulletin. July 17, 1974, 1.

“ACI Budget Up \$1.2 Million.” The Providence Journal Bulletin. November 12, 1970, 1.

“ACI Called ‘a Jungle’ by Correction Official.” The Providence Evening Bulletin. September 16, 1971, 27.

“ACI Doubling Up Inmates in Cells. May Lay Off 50 Members of Staff.” The Providence Journal. October 1, 1981, A1.

“ACI Guard Suspension Is Protested by Union.” The Providence Journal. December 7, 1971, 30.

"ACI Guards and State Reach Tentative Accord.” The Providence Evening Bulletin. February 13, 1974, C4. 
“ACI Guards Bow to Judges Order to Work.” The Providence Journal. February 20, 1981, A3.

"ACI Guards Demand Change in Interview with the Warden." The Providence Journal. August 18, 1970, 45.

“ACI Guards Elect Officers for Two Years.” The Providence Evening Bulletin. November 6, 1975, B3.

“ACI Guards Eye New Labor Union.” The Providence Journal Bulletin. December 18, 1970, 29.

“ACI Guards Fired After Inmate Incident.” The Providence Evening Bulletin. July 16, 1974, A1.

“ACI Guards Fired; Guardsmen Move In.” The Providence Journal. July 17, 1974, 1.

“ACI Guards Get Pay Increase.” The Providence Journal. November 30, 1972, 1.

“ACI Guards Hold A Protest Meeting.” Providence Evening Bulletin. October 18, 1972, 2.

“ACI Guards Protest Over Crowding. Cite Mismanagement.” The Providence Journal. September 16, 1988, A3.

“ACI Guards Reject Pact; Call Pay Inadequate.” The Providence Evening Bulletin. December 28, 1973, 2.

“ACI Guards Threaten to Refuse Overtime in Dispute Over Contract.” The Providence Evening Bulletin. January 7, 1974, 21.

"ACI Guards Vote to Suspend Union Head Pending Hearing." The Providence Journal. September 26, 1980, C7.

“ACI Guards Will Get 5.5\% Raises in New Contract. Moran Says.” The Providence Journal. November 16, 1985.

“ACI Guards Win on Lockup Issue.” The Providence Evening Bulletin. May 31, 1973, 1.

“ACI Inmates Balk at Going to Cells.” The Providence Journal. January 2, 1974, 9.

“ACI Inmates Claim Prison Violates Rights.” The Providence Evening Bulletin. June 29, 1970, 29. 
“ACI Inmates Propose 4 Bills to R.I. Senators.” The Providence Journal. February 16, 1971, 31.

“ACI Inmate Sentenced to 2 Years.” The Providence Journal. August 9, 1974, B10.

“ACI Inmates Sue State for Improvements.” The Providence Journal. February 8, 1975, 5.

“ACI Job Efforts Hurt By Statute.” The Providence Journal. December 13, 1976, A5.

“ACI Labor Dispute Apparently Resolved.” The Providence Journal. December 10, 1971, 25.

“ACI launching Full Vocational Program.” The Providence Journal Bulletin. January 2, 1970, 19.

“ACI Lockup to be Modified.” The Providence Evening Bulletin. November 13, 1975, A1.

“ACI Officers. Licht Discuss New Contract.” The Providence Journal. October 27, 1972, 8.

“ACI Officials Confer on Unrest.” The Providence Journal Bulletin. November 1, 1971, 1.

“ACI Officials Experiment with 'Family Day'.” The Providence Journal. August 10, 1970, 26.

“ACI Orders Lockup After 90 Minute Protest.” The Providence Journal. September 27, 1985, A1.

“ACI Overcrowded Despite Supermax.”The Providence Evening Bulletin. March 3, 1981, A1.

“ACI Prisoner Groups Urge Support for Warden.” The Providence Sunday Journal. January 15, 1972, 12.

“ACI Prisoners. Guards Injured in 'Minor Riot.”' The Providence Journal. August 8, 1976, A1.

“ACI Prisoners Brutality Case Ruling is Near.” The Providence Evening Bulletin. August 15, 1974, B6.

“ACI Repairs Windup Promised.” The Providence Journal Bulletin. January 10, 1970, 1. 
“ACI Seeks to Penalize Late Guards.” The Providence Journal. November 10, 1983, A3.

“ACI Starts In-Service Training.” The Providence Journal. June 13, 1972, 29.

“ACI Takeover Seizure of Guards Foiled.” The Providence Evening Bulletin. November 20, 1971, 1.

“ACI to Offer New Job-Training Courses.” Providence Evening Bulletin. June 12, 1970, 28.

“ACI Transfers Four Prisoners After Assault.” The Providence Journal. January 19, 1971, 1.

“ACI Uprising Tied to Rivalry Among Blacks.” The Providence Evening Bulletin. April 3, 1973, 24.

“ACI Warden Backs Jobs Inside Prison.” The Providence Journal. December 4, 1973, 11.

“ACI Warden Bans Parties of Inmate Organizations.” Providence Journal. January 20, 1971, 16.

“ACI Warden. Official ‘Resolve’ Dispute.” The Providence Journal. January 22, 1972, 13.

“ACI Worker Suggests Overtime Relief Proposal.” The Providence Evening Bulletin. March 8, 1973, 19.

“ACI’s Population is Highest Ever.” The Providence Journal. February 14, 1984, A3.

“ACLU Opposes ‘Privatization’ of State Prisons. Corrections Officers Union Also Questions Option.” The Providence Journal. January 1, 1988, A3

“ACLU. Guards Criticize Home Confinement Bill.” The Providence Journal. June 20, 1989, A6.

"Assembly Oks Death Bill. Revamped Regents Board.” The Providence Journal. June 27, 1973, 1.

“Attica Revolt.” The Providence Evening Bulletin. September 14, 1971, 28.

"Blazes Damages Shop Building in Maximum Security Unit.” The Providence Journal. April 4, 1985, D4. 
“Bond Issue for ACI Backed by Chiefs.” The Providence Journal. October 10, 1976, A7.

“Bulletin: Warden Resigns Post.” The Providence Evening Bulletin. April 4, 1973, 1.

“Bungling at ACI.” The Providence Journal. September 24, 1971, 62.

“Chronic ACI Troublemakers Placed in Special Cellblock.” The Providence Journal. July 1, 1973, B7.

“Conditions at ACI Likened to Those at Attica.” The Providence Evening Bulleting. October 1, 1971, 29.

“Court Hearing Today on New Lockup at ACI.” The Providence Journal. December 2, 1975, A6.

“Course Set for ACI Guards.” The Providence Evening Bulletin. December 21, 1972, 36.

"Disturbance Staged by 20 at the ACI.” The Providence Evening Bulletin. December 11, 1969, 1.

“Do People of R.I. Want 'Alcatraz-type’ Facility or Efforts to Rehabilitate?.” The Providence Journal Bulletin. November 16, 1971, 1.

“Don’t Need New Guards to Get Funds.” The Providence Journal. February 4, 1977, A4.

“Embarrassed.” The Providence Journal. September 24, 1971, 62.

"Garabedian Intends to File Bill for 25 More ACI Guards." The Providence Journal. June 25, 1973, 25.

“GOP criticizes Licht on Personnel at ACI.” The Providence Journal Bulletin. August 26, 1970, 43.

“Gov. Enters ACI Dispute.” The Providence Evening Bulletin. January 13, 1972, 1.

“Ground Broken for Construction of Supermax.” The Providence Evening Bulletin. June 27, 1977, A20.

“Guards Air Problems with Officials at the ACI.” The Providence Journal Bulletin. August 20, 1970, 30.

“Guard Averts ACI Breakout.” The Providence Evening Bulletin. December 20, 1972, 1. 
“Guard Chief Hints at Action on Contract.” The Providence Journal. February 8, 1974, B4.

“Guard Shift at ACI Out 'Sick'.” The Providence Journal. November 20, 1972, 1.

“Guard Stabbed to Death at ACI.” The Providence Journal. June 22, 1973, 1.

“Guard Union Trial Board Fires Suspended President Michael Solitro.”The Providence Evening Bulletin October 3, 1980, A9.

“Guards and State Strike Tentative Accord.” The Providence Journal. December 22, 1983, B10.

“Guards Ask House Unit to Visit ACI.” The Providence Journal. April 12, 1977, A6.

“Guards Back. Licht Slates Talks Today.” The Providence Journal. November 21, 1972, 1.

“Guards call in sick job action.” The Providence Journal. February 19, 1981, A3.

“Guards Hold 'Sickout’. Relent.” The Providence Journal. January 17, 1973, 1.

“Guards’ Labor Parley Fails.” The Providence Evening Bulletin. December 5, 1975, B1.

"Guards. Officials at ACI Agree to Daily Meetings.” The Providence Journal. August 21, 1970, 34.

“Guards’ Union President Takes Council 70 Post.” The Providence Journal. March 19, 1976, B4.

“Guards Saw A Simple Issue. and Noel Had A Simple Answer.” The Providence Journal. July 21, 1974, F1.

"Guards training period cut from six weeks to two.” The Providence Journal. June 23, 1973, 8.

“Guards Win Compensation for Work on Break Time.” The Providence Evening Bulletin. November 21, 1985, A22.

“Hunger Strike At ACI.” The Providence Journal. December 22, 1974, B6.

“Inmate Escapes from State Prison.” The Providence Journal. December 28, 1972, 10.

“Inmate Strikes ACI Guard.” The Providence Journal Bulletin. December 30, 1972, 6. 
"Inmate Strolled Off. Count at ACI Shows.” The Providence Journal. August 8, 1970, 18.

“Inmates Cite Buildup of Tension and Blame ACI Deputy Warden.” The Providence Journal. April 3, 1973, 6.

“Inmates Stand Off Police for 2 and a half Hours Before Giving In.” The Providence Journal. October 1, 1985, A1.

"Inmate Suit Mounts Broad Attack on ACI." The Providence Journal Bulletin. December 19, 1969, 41.

“Judge Grande Orders Guards to End Sickout.” The Providence Journal. August 30, 1983, A1.

"Judge Stiffens Ban on Strikes By Guards at ACI.” The Providence Evening Bulletin. February 26, 1981, A14.

“Keeping a Gag on the ACI.” The Providence Journal. October 29, 1977, A22.

“Killing Stirs Backlash.” The Providence Journal. June 23, 1973, 1.

“Leadership at ACI.” The Providence Evening Bulletin. July 7, 1972, 22.

"Licht Confirms Plot for Uprising. Hostages at ACI.” The Providence Evening Bulletin. November 24, 1971, 1.

“Licht Defends ACI Pact.” The Providence Journal. December 2, 1972, 10.

"Licht Signs Pact Giving Pay Hikes to Guards at ACI.” The Providence Journal. December 7, 1972, 8.

“Management Say for Guards.” The Providence Evening Bulletin. June 1, 1973, 1.

“Mandatory Jailing and Prison Overcrowding." The Providence Journal. March 17, 1981, A22.

"Mass. Lawyer is New ACI Warden.” The Providence Evening Bulletin. March 13, 1970, 1.

"Moran Faces Task of ACI Revamp Without Help of RI Voters.” The Providence Journal. November 5, 1982, A3.

"Moran Opposes NPRA at ACI; Discloses Drunk Driving Arrest.” The Providence Journal. February 22, 1978, A4. 
“More Guards Seen ACI Need.” The Providence Evening Bulletin. November 4, 1972, 23.

“New Contract Proposal Offered By ACI Guards.” The Providence Journal. January 23, 1974, B3.

“New Standards Urged for the ACI.” The Providence Journal. March 31, 1971, 24.

“New Warden’s Worries: ‘Budget. Budget. Budget.” The Providence Evening Bulletin. November 6, 1981, A3.

“Nine ACI Guards Deny Assaulting Prison Inmates.” The Providence Journal. August 10, 1973, 9.

“Noel Sets Tighter Security at ACI.” The Providence Evening Bulletin. June 1, 1973, 1.

“Noel Will Decide Changes at ACI.” The Providence Evening Bulletin. April 5, 1973, 1.

“Noel’s Governor. Not God. Fagnant Says.” The Providence Journal. September 5, 1975, A4.

“Officials Believe 4 Escapees Armed.” The Providence Journal. September 21, 1972, 1.

“Pettine Weights Fines as Means to Reduce Crowding at Prison.” The Providence Journal. May 24, 1987, A3.

“Police Fill in For Guards.” The Providence Evening Bulletin. April 9, 1973, 12.

“Policy Test at ACI.” The Providence Journal. December 7, 1977, A14.

“Priority Urged for Intake Center.” The Providence Journal. November 20, 1975, A26.

“Prison Guard Fund Cut Questioned.” The Providence Journal. April 27, 1973, 14.

"Prison Guards Elect Union Slate at ACI.” The Providence Journal. December 3, 1987, A28.

“Prison Guards Found in Contempt.” The Providence Journal. December 17, 1983, A5. 
"Prison Guards Refuse to Work. Receive Pledge.” The Providence Evening Bulletin. January 18, 1971, 1.

“Prison Guards Work Long. Tense Hours.” The Providence Sunday Journal. October 17, 1971, A1.

“Prison Reform.” The Providence Journal. November 13, 1971, 21.

“Prison Reform Delicate.” The Providence Journal Bulletin. November 10, 1971, 1.

“Prison Retaken; At Least 37 Die.” The Providence Journal. September 14, 1971, 1.

“Prisoner Walks Away from ACI While At Work.” The Providence Journal. July 28, 1970, 6.

"Prisoner Work Bill is Passed by the Senate.” The Providence Journal Bulletin. April 29, 1970, 37.

“Progress Made in ACI Repairs.” The Providence Journal. February 3, 1970, 17.

“Proposal rejected by Noel.” The Providence Journal. January 24, 1974, B1.

“Proposals Made by Probe Group.” The Providence Journal. November 3, 1972, 7.

“Protest Stalled Pension Bill.” The Providence Journal Bulletin. July 6, 1971, 1.

“Replacing ACI Building Urged.” The Providence Journal. November 17, 1971, 1.

“Report on Lost ACI Funds Due in Week.” The Providence Journal. July 7, 1972, 31.

“R.I. Prison Official Says Reforms Not Lax.”The Providence Evening Bulletin. March 26, 1973, 20.

“Ronald Brodeur. Again Leader of ACI Guards’ Union.” The Providence Journal. December 4. 1985. A14.

“Secrecy at the ACI.”The Providence Evening Bulletin. November 23, 1971, 22.

"Seminar for Guards at ACI Ends.” The Providence Evening Bulletin. May 8, 1972, 38.

“Senate Passes Furlough Bill for Prisoners.” The Providence Journal. May 20, 1971, 9.

"Sources at ACI Report New Warden Cracking Down.” The Providence Evening Bulletin. May 16, 1973, 47. 
“State Considers Short Work Week.” The Providence Journal. February 1, 1975, 7.

“State Finally Opens Supermax.” The Providence Evening Bulletin. January 29, 1981, A1.

"State of Emergency: Guards 'Sick.'” The Providence Evening Bulletin. February 19, 1981, A1.

“State Offers Education to ACI Inmates.” The Providence Journal. June 5, 1970, 10.

“'Supermaximum’ Prison Backed by ACI Union.” The Providence Journal. September 18, 1975, A14.

“Three ACI Bills Are Introduced.” The Providence Journal. March 6, 1970, 14.

“Three Convicts Flee Maximum Security at ACI.” The Providence Journal. October 26, 1970, 1.

“Top Security ACI Inmates Return Set.” The Providence Journal. February 25, 1970, 2.

“Top Security ACI Inmates to be Moved.” The Providence Journal. March 3, 1970, 17.

“Tough Stuff.: Back on the Job After Facing the Worst.” The Providence Journal. April 14, 1985, E1.

“Travisano Agrees With Philosophy of Report.” The Providence Evening Bulletin. July 5, 1972, 60.

“Troopers on Duty in ACI Sickout.” The Providence Evening Bulletin. November 20, 1972, 1.

“Trouble Continues Despite the Lockup.” The Providence Evening Bulletin. June 1, 1973, 10.

“Two Bills Aimed at Prison Riots.” The Providence Journal. April 7, 1973, 11.

“Union Defends Itself on Sick Leave.” The Providence Journal. February 13, 1976, A14.

“Union Guards at ACI Elect a New President.” The Providence Evening Bulletin. October 16, 1973, 17. 
"Union Head: Staff at ACI is Overworked. Underpaid.” The Providence Journal. February 15, 1972, 23.

"Union Says Prison Broke Contract. Forced Guards to Work Overtime Over $4{ }^{\text {th }}$ of July Weekend.” The Providence Journal. July 7, 1988, B18.

“Unrest at Attica Termed National.” The Providence Evening Bulletin. September 14, 1971, 25.

“Versions Differ on Saturday’s ACI Rebellion.” The Providence Journal. November 1, 1971, 1.

“Void Noel Order. Six Petition in Court.” The Providence Journal. March 26, 1975, B1.

“Warden Denies Resigning; Says He’s on Sick Leave.” The Providence Journal. April 5, 1975, 1.

“Warden Expects Unrest at ACI.” The Providence Journal. October 7, 1971, 3.

“Warden of ACI Resigns.” The Providence Evening Bulletin. April 18, 1973, 1.

"Warden Predicts ACI Disruptions.” The Providence Evening Bulletin. November 28, 1972, 1.

"Warden Scores GOP's 'Partisan Politics' in Attack on ACI.” The Providence Journal Bulletin. August 27, 1970, 33.

"Where does long range planning for the ACI go from here?." The Providence Journal. November 11, 1976, A30.

“Who’s in Charge." Providence Journal. Metro-West edition. October 4, 1991, Sec A 14 (editorials).

“Women.” Providence Evening Bulletin. April 6, 1973, 1.

“Women’s Prison Has Disturbance.” The Providence Journal. April 7, 1973, 10.

“Work-Release Bill Delayed for Hearing.” The Providence Journal. February 26, 1972, 14.

“Work-Release Bill Returned to Committee.” The Providence Journal. March 2, 1972, 20.

“Work Release Plan for Lifers Opposed.” The Providence Journal. February 25, 1972, 23. 
"Year of Strikes - Maybe More Coming.” The Providence Journal. January 4, 1970, F16.

Abood, Don. "ACI Called Tense After 3 Guards Are Assaulted By a Young Inmate.” The Providence Evening Bulletin. August 8, 1974, A2.

Abood, Don. “ACI Guards Launch Health Fund Drive.” The Providence Journal. August 21, 1974, B1.

Abood, Don. “ACI Study Suggests Reforms.” The Providence Journal. May 8, 1974, A1.

Abood, Don. “Early Decision Held Unlikely On ACI.” The Providence Journal. January 8, 1974, 25.

Abood, Don. “'They'd rather be out of a job than see an officer killed.” The Providence Journal. July 17, 1974, A1.

Allen, Hamilton. “ACI Chief Would Replace Maximum Security Unit.”The Providence Journal. April 20, 1977, B4.

Allen, Hamilton. “ACI Guards Blame State on Overtime.” The Providence Journal. June 7, 1974, B2.

Allen, Hamilton. “ACI Guard's Overtime $\$ 800.000$ Despite Overtime Ban.”The Providence Evening Bulletin. June 4, 1974, A1.

Allen, Hamilton. “ACI Suit Moot - No Money.” The Providence Journal. January 30, 1975, A1.

Allen, Hamilton. "Guards at ACI Quit Panel Appointed By Pettine to Study Prisoners' Suits.” The Providence Evening Bulletin. May 18, 1977, D1.

Allen, Hamilton. “Judge Warns He May Close State Prison.” The Providence Journal. December 3, 1975, A1.

Allen, Hamilton. "Prison Expert Says ACI Unfit for Human Habitation.” The Providence Journal. April 14, 1977, B1.

Bakst, Charles. "Noel: Use Any Means To Control Prison.” The Providence Journal. June 12, 1973, 1.

Baldwin, Robert. “ACI Beginning to Put Emphasis on Rehabilitation.” The Providence Journal. May 17, 1970, N27. 
Baldwin, Robert. “ACI Inmates Start ‘Take-out’ Food Service.” The Providence Journal. January 5, 1974, 7.

Baldwin, Robert. “ACI Needs More Guards.” The Providence Journal. August 23, 1970, N1.

Baldwin, Robert. “ACI Still Short of Fulfilling Changes.” The Providence Sunday Journal. February 8, 1970, N 36.

Baldwin, Robert. “ACI Warden Backs Prison Reform Bills.” The Providence Journal. February 15, 1972, 23.

Baldwin, Robert. "20 Inmates Go Without Any Supper.” The Providence Journal. December 12, 1969, 18.

Baldwin, Robert. "Little Support Given to ACI Furloughs Bill.” The Providence Journal. April 25, 1972, 30.

Baldwin, Robert "More Hiring Eyed to Cut Overtime.” The Providence Journal. March 8, 1973, 2.

Baldwin, Robert. "Prison Reform Approaches Differ.” The Providence Journal. February 7, 1972, 1.

Baldwin, Robert. "Proposed Prison Complex Too Big?.” The Providence Sunday Journal. May 14, 1972, C8.

Baldwin, Robert. "Reform at ACI Still Favored by Travisano." The Providence Journal. April 6, 1973, 1.

Baldwin, Robert. "R.I. Prison System Assailed by Officials.” The Providence Sunday Journal. February 6, 1972, 1.

Baldwin, Robert. "Some Wardens Are Prisoners Too.” The Providence Sunday Journal. September 12, 1971, M30.

Baldwin, Robert. “Target of ACI Rebels Had Been Reassigned.” The Providence Journal. April 2, 1973, 29.

Baldwin, Robert. “Warden Says He May Quit In Operational Dispute.” The Providence Journal. January 13, 1972, 1.

Baron, Stephen. "Union Chief Bristles at ACI Criticism.” The Providence Journal. December 12, 1975, B1. 
Boyd, Lester. “ACI Guards Reluctantly Return to Work.” The Providence Evening Bulletin. July 7, 1971, 31.

Breton, Tracy. “ACI Decentralization Favored by Travisono.” The Providence Evening Bulletin. January 19, 1974, 5.

Donnelly, David . “ACI Alerted. but 4 Flee.” The Providence Evening Bulletin. September 21, 1972, 1.

Donnelly, David. “ACI Endangered Guard.” The Providence Evening Bulletin. November 6, 1972, 1.

Donnelly, David. “ACI Gains New Security.” The Providence Evening Bulletin. October 9, 1973, 1.

Donnelly, David. "Escape Tunnel Dug by 10 is Found.” The Providence Evening Bulletin. June 29, 1973, 1.

Donnelly, David. “Escapes Test Rehabilitation.” The Providence Journal Bulletin. December 24, 1970,1.

Donnelly, David. “Guards: Not Alerted on Flight Plot.” The Providence Evening Bulletin. September 22, 1972, 1.

Donnelly, David. “Hard Line Policy for ACI.” The Providence Evening Bulletin. June 12, 1973, 1.

Donnelly, David. “New Warden to Seek Help of Ex-Inmates.” The Providence Evening Bulletin. March 30, 1970, 1.

Donnelly, David. “Overcrowding Strains ACI Top-Security Unit.” The Providence Evening Bulletin. April 10, 1973, 1.

Donnelly, David. “Travisano Answered by Guards.” The Providence Evening Bulletin. April 6, 1973, 1.

Donnelly, David. “Why It Happened.” The Providence Sunday Journal. April 8, 1973, G1.

Gariepy, Tom. “ACI Guard Union Head Attacks Pettine Ruling.” The Providence Journal. August 12, 1977, A29.

Gariepy, Tom. “Officials of ACI Guards Union Will Meet With Southworth.” The Providence Journal. August 3, 1977, A8.

Gariepy, Tom. “Solitro Seeks Presidency of Guards’ Union At ACI.” The Providence Journal. August 2, 1977, A8. 
Giacobbe, Paul. “3 Overtime Studies on ACI Never Used” The Providence Journal. March 25, 1976, B4.

Giacobbe, Paul. “4 Guards Assaulted at State Prison.” The Providence Journal. August 20, 1974, B1.

Giacobbe, Paul. “Absences at ACI Called an Attempt to 'Break' Noel's Austerity Program.” The Providence Evening Bulletin. February 25, 1975, B4.

Giacobbe, Paul. “ACI Inmates Score Crowded Conditions.” The Providence Journal. September 11, 1976, 5.

Giacobbe, Paul. “ACI Guard Pact Insures Overtime.” The Providence Evening Bulletin. March 25, 1976.

Giacobbe, Paul. “ACI Guards In Near Walkout.” The Providence Evening Bulletin. November 12, 1975, D5.

Giacobbe, Paul. “ACI Officials. Union Blamed for Problems.” The Providence Journal. December 11, 1975, A1.

Giacobbe, Paul. “ACI Officials Worry About Sex-Bias Issue.” The Providence Evening Bulletin. May 10, 1976, B1.

Giacobbe, Paul. “ACI Sick Leave 'Racket' Charged.” The Providence Journal. February 12, 1976, B1.

Giacobbe, Paul. “After High Overtime. a Shorter ACI Work Week.” The Providence Journal. February 16, 1975, 11.

Giacobbe, Paul. “Arms Alarm Causes ACI Inmate Lockup.” The Providence Journal. July 20, 1976, A1.

Giacobbe, Paul. “Guards’ Union Head Back Warden’s Acts.” The Providence Evening Bulletin. November 5, 1975, 22.

Giacobbe, Paul. “Lockup Linked to Referendum?.” The Providence Evening Bulletin. October 27, 1976, D4.

Giacobbe, Paul. “Modified ACI Lockup Calm; 100 Troopers. Guards Hover.” The Providence Journal. November 15, 1975, 1.

Giacobbe, Paul. “Tighter ACI Job Controls Urged.” The Providence Journal. March 4, 1976, A18. 
Giacobbe, Paul and Dan Abood. "Disorders At ACI Flare Twice in Day.” The Providence Journal. February 28, 1975, A1.

Giacobbe, Paul and Dante Ionata. "Armed ACI Inmates Seize Guard; Officials Argue on 'No repraisals'." The Providence Journal. November 26, 1972, A1.

Hackett, John. "Death Penalty Bill Prepared for Assembly.” The Providence Journal. June 26, 1973, 1.

Hackett, John. “New Guards Jobs at ACI Unfilled.” The Providence Journal. November 16, 1973, 27.

Hackett, John. “Noel Confident ACI Guards Won’t Hold Slowdown.” The Providence Evening Bulletin. January 17, 1974, 27.

Hackett, John. "U.S. Stalls ACI Radio Updating." The Providence Evening Bulletin. July 9, 1973, 1.

Hackett, John and Ron Winslow. "Action Vowed Today In Racial Brawl at ACI.” The Providence Journal. August 6, 1976, B1.

Harrington, Michael. "Union Militancy On the Rise.” The Providence Journal. January 29, 1972, 15.

Howard, Peter. "Damage assessed in ACI Riot Aftermath: Lockdown continues until all weapons are confiscated." Providence Journal. City Final edition. October 5, 1991, Sec A3.

Hulick, Doane. "Deputy Corrections Chief Blames Ills At Prison on 'Incompetence.”' the Providence Journal. February 8, 1975, 5.

Hulick, Doane. “R.I. Crime bd. Okays $\$ 90.000$ for ACI.” The Providence Journal. October 5, 1973, 3.

Hulick, Doane. "Troopers May Stay at ACI Posts for 3-4 More Months.” The Providence Journal. July 24, 1973, 38.

Ionata, Dante. "Licht Statement on ACI: Won't 'Second-Guess'." The Providence Journal. November 28, 1972, 1.

Kelly, Paul. "Capt. Mullen Appointed ACI Warden.” The Providence Evening Bulletin. May 7, 1973, 1.

Kelly, Paul. "Changes at ACI.” The Providence Evening Bulletin. July 26, 1972. 1, 
Kelly, Paul. "Garrahy Hits Time in Court.” The Providence Evening Bulletin. May 12, 1977, B1.

Kelly, Paul. "Governor Noel: Special Force to Handle ACI Strife.” The Providence Evening Bulletin. September 5, 1973, 1.

Kelly, Paul. "Guards to ask Pettine to suspend rules for 'hard core' prisoners.” The Providence Journal. September 28, 1974, 7.

Kelly, Paul. "Noel Submits 3 Bills on ACI Reform.” The Providence Evening Bulletin. April 2, 1975, A1.

Kelly, Paul. “'State’s Correctional Systems Do Not Correct.” The Providence Evening Bulletin. July 5, 1972, 1.

Kiffney. John “ACI Offer Made By Noel.” The Providence Journal. January 15, 1974, A1.

Korb, David. "72 Inmates Will be Transferred to Medium Security Unit.” The Providence Journal. December 16, 1974, B3.

Korb, David. “ACI Guards Ask Study of High Security Unit.” The Providence Journal. December 1, 1974, B14.

Korb, David. “ACI Inmates Won’t Leave Building.” The Providence Journal. December 19, 1974, B1.

Korb, David. "Assault of ACI Official Leads to Confrontation. Lockup.” The Providence Journal. September 15, 1974, B13.

Korb, David. "Brutality Probers Give Report to ACI Officials.” The Providence Journal. November 30, 1974, 8.

Korb, David. “Guards’ Union at ACI to Test a Regulation.” The Providence Journal. December 7, 1974, 11.

Korb, David. “Guards Union to Request a Probe of 'Chaos' at ACI.”The Providence Evening Bulletin. December 7, 1974, D4.

Korb, David. "Inmate Gets 30 Days for Assault.” The Providence Journal. July 19, 1974, A7.

Korb, David. "It was just like a day at the beach but participants were in prison.” The Providence Journal. August 11, 1974, B1. 
Korb, David "Mullen orders lock-up at ACI after stabbing. assault cases.” The Providence Journal. August 16, 1974, A1.

Landis, Bruce. "Prison-guard contract bill vetoed.” The Providence Journal. June 18, 2004, B6.

Lelveld, Joseph. “Attica Guards' Families React to Report Hostages Were Shot.” The Providence Evening Bulletin. September 15, 1971, 37.

Luskin, Robert and Paul Giacobbe. “ACI Guard Contract Talks Fail.” The Providence Journal. December 19, 1975, A1.

McKay, Scott. "Judge says arbitration is proper method.” The Providence Journal. December 8, 2006, B1.

McKay, Soctt. "Judge says arbitration is proper method.” The Providence Journal. December 8, 2006, B1.

Meade, Laura. "Prisoners at ACI transferred out of R.I..” Providence Journal. City Final Edition. October 6, 1991, Sec B 1.

Mooney, Tom. “ACI Riot backfired. inmates discover.” Providence Journal. City Final edition. November 2, 1991, Sec A 3.

Mooney, Tom. "300 inmates in 5-hour standoff with ACI guards. state troopers.” The Providence Journal. October 1, 1991, A1.

Mooney, Tom. "Prison Guards Ratify 2-year Deal With State; Pact Fails to Please Everybody. but Union Chief Claims Victory.” The Providence Journal. October 25, 1989, A3.

Mooney, Tom. “ACI Guards. State Agree on a Contract.” The Providence Journal. October 18, 1989, A1.

Mooney, Tom. "Prison Guards Ratify 2-year Deal With State; Pact Fails to Please Everybody. but Union Chief Claims Victory.” The Providence Journal. October 25, 1989, A3.

Morin, Stephen. "The New Prison Boss is No Stranger to the Toughest Job in Town." The Providence Journal. February 5, 1978, A1.

Morin, Stephen. “Pettine to Oversee Pact Between ACI and Guards' Union.” The Providence Journal. November 16, 1977, A1.

Morin, Stephen and John Kiffney. "Laurie Walks Out On ACI Probers.” The Providence Journal. August 31, 1977. 
Morgan, Thomas. “ACI Guard Cutback Planned; Saving Set at $\$ 7.000$ a Week.” The Providence Journal. May 19, 1977. B1.

Morgan, Thomas. “Black Inmates See White Plot in Racial Row.” The Providence Journal. August 4, 1976, B1.

Narsavage, David. "New Guards See Discipline 'Mess.” The Providence Evening Bulletin. January 3, 1974, 1.

Narsavage, David. “The Job’s Potential Excites Him.” The Providence Evening Bulletin. January 7, 1974, 1.

Popkin, George. "He Provides a Valve for the Endless Days.” The Providence Journal Bulletin. January 6, 1970, 2.

Prosnitz, Franklin. “2 ACI Guards Held Hostage for Half-Hour.” The Providence Journal. June 11, 1973, 1.

Prosnitz, Franklin. “3 Guards Seized By Inmates in New Disturbance at ACI.” The Providence Journal. June 3, 1973, 1.

Prosnitz, Franklin. “ACI Plan May Include Community Centers.” The Providence Journal. March 7, 1974, A11.

Rakowsky, Judy. "With a Heavy Heart. Judge Pettine Leaves ACI. Brown Cases.” The Providence Journal. May 3, 1989, A1.

Richard, Randall. “Judge Faces ACI Guards on New Rules.” The Providence Journal. August 4, 1970, 1.

Rooney, George and Jack Spratt. "Day the ACI 'Exploded.'” The Providence Journal. April 3, 1973, 7.

Rosenthal, James and Don Abood. "Stunned ACI Guards angry. bitter. and determined.” The Providence Evening Bulletin. June 23, 1973, 8.

Schwardron. Terry. “ACI Inmates. Guards Join Forces In Opposing Reduction of Staff.” The Providence Journal. May 21, 1977, 22.

Schwardron. Terry. “ACI Seen Staying in Cranston.” The Providence Journal. January 18, 1974, B1.

Schwardron. Terry. “Guards Ask Meeting Over ACI 'Unrest.”' The Providence Evening Bulletin. July 19, 1976, A6. 
Schwardron. Terry. "Guards Set to Accept Overtime.” The Providence Journal. January 25, 1974, A15.

Schwardron. Terry. “'No White Conspiracy' Uncovered in Probe of Racial Brawl at ACI.” The Providence Journal. August 7, 1976, 32.

Sekeres, Joel. “53 Guards Veto Extra Shift.” The Providence Journal. January 22, 1974, A1.

Sekeres, Joel. "Noel Approves Plan to Hire 77 ACI Guards.” The Providence Journal. June 27, 1973, 19.

Sekeres, Joel. "Report Hits Warden. State Police Officer.” The Providence Journal. November 3, 1972, 1.

Sekeres, Joel. "Voters OK bonds for roads. prisons.” The Providence Journal. June 29, 1977, A1.

Steele, Duane. “ACI Guards Expect More Charges.” The Providence Evening Bulletin. November 29, 1974, B3.

Steele, Duane. "One Senator Attends ACI Legislation Forum.” The Providence Journal. February 20, 1972, 27.

Stickler, Robert. “Garrahy Asks Probe of ACI 'Overreaction.”' The Providence Journal. August 29, 1977, A3.

Stickler, Robert. "Prison Guards Win Fight for Overtime.” The Providence Journal. August 14, 1975, A1.

Stocker, Elliot. “Judge ‘Hears’ Prisoners.” The Providence Evening Bulletin. March 11, 1970, 1 .

Trahan, Emilie. "When in the Course of Human Events...." The Providence Journal Bulletin. December 18, 1970, 30.

Walsh, Thomas. "ACI Guard Brings Letter to Governor: Warns Jail 'could explode any time.”” The Providence Journal. July 30, 1977, 1.

Welt, William. “'Experts’ Tell of Life Inside ACI: Prison Found Not Correctional.” The Providence Sunday Journal. October 10, 1971, A1.

Winslow, Ron and Gina Macris. "Prisons Head Acknowledges Inmates' Sway.” The Providence Journal. August 1, 1977, A1. 
Wood, Edward. "Rampage Leaves ACI in Shambles.” The Providence Journal. April 3, 1973, 1.

Worcester, Wayne. “ACI Union Rejects Noel Plan.” The Providence Journal. January 16, 1974, A11.

Wyss, Bob. "Southworth Must Make Plan for Press at ACI." The Providence Journal. June 28, 1977, A1.

Wyss, Bob. “The ACI: A ‘Country club’ or a Hellhole?.” The Providence Journal. April 10, 1977, C1.

\section{Secondary Sources}

Monographs:

Who Built America. The American Social History Project. Worth Publishers. New York, NY, 2000.

Bernstein, Lee. America is the Prison: Arts and Politics in the Prison in the 1970's. Chapel Hill: University of North Carolina Press, 2010.

Boyer, Richard and Herbert Morais. Labor's Untold Story. United Electrical, Radio \& Machine Workers of America. Cameron Associates. New York, N.Y., 1955.

Blomberg, Thomas G. American Penology : A History of Control. New Brunswick, N.J. : AldineTransaction, 2010.

Carroll, Leo. Hacks, Blacks, and Cons : Race Relations in a Maximum Security Prison. Lexington, Mass. : Lexington Books, 1974.

Carroll, Leo. Lawful Order : A Case Study of Correctional Crisis and Reform. New York : Garland Pub., 1998.

Cowie, Jefferson. Stayin' Alive: The 1970's and the Last Days of the Working Class. New York : New Press, 2010.

Dubofsky, Melvyn. The State \& Labor in Modern America. Chapel Hill : University of North Carolina Press, 1994.

Foucault, Michel. Discipline and Punish : the Birth of the Prison. New York : Pantheon Books, 1977.

Rosenblum, Jonathan D. Copper Crucible : How the Arizona Miners' Strike of 1983 Recast Labor-management Relations in America. Ithaca, N.Y. : ILR Press, 1995. 
Rosswurm, Steve. The CIO's Left-led Unions. New Brunswick, N.J. : Rutgers University Press, 1992.

Scholarly Articles:

Cowie, Jefferson. "Portrait of the Working Class in a Convex Mirror: Toward a History of the Seventies." Labor: Studies in Working Class History of the Americas 2, no. 3 (Fall2005 2005): 93-102. America: History \& Life, EBSCOhost (accessed February 23, 2011).

Rouverol, Alicia J. "Collaborative Oral History in a Correctional Setting: Promise and Pitfalls." The Oral History Review 30, no. 1 (Winter - Spring, 2003): pp. 6185, http://0-www.jstor.org.helin.uri.edu/stable/3675352.

Website:

Rhode Island Brotherhood of Correctional Officers. “About Us.” http://www.ribrotherhood.com/aboutus.php (accessed April 11, 2012). 